DOE/NASA/0126-1

NASA CR-165260

FCR-1784

\title{
Cost Projections for Redox Energy Storage Systems
}

Final Report

April 30, 1979—September 30, 1979

Kenneth Michaels and Gene Hall United Technologies Corporation
NASA-CR-165260
19810016635
$\mathbf{O X}$
$\mathbf{7 9}$

NASA-CR-165260
19810016635
$\mathbf{O X}$
$\mathbf{7 9}$
For Rererence

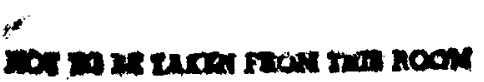

February 1980

Prepared for

NATIONAL AERONAUTICS AND SPACE ADMINISTRATION

Lewis Research Center

Under Contract DEN 3-126

for

U.S. DEPARTMENT OF ENERGY

Conservation and Solar Energy

Division of Energy Storage Systems

dul 201969 


\section{NOTICE}

This report was prepared to document work sponsored by the United States Government. Neither the United States nor its agent, the United States Department of Energy, nor any Federal employees, nor any of their contractors, subcontractors or their employees, makes any warranty, express or implied, or assumes any legal liability or responsibility for the accuracy, completeness, or usefulness of any information, apparatus, product or process disclosed, or represents that its use would not infringe privately owned rights. 
DOE/NASA/0126-1

NASA CR-165260

FRC-1784

\section{Cost Projections for Redox Energy Storage Systems}

\section{Final Report}

\section{April 30, 1979-September 30, 1979}

Kenneth Michaels and Gene Hall United Technologies Corporation Governors Highway

South Windsor, Connecticut 06074

February 1980

Prepared for

National Aeronautics and Space Administration

Lewis Research Center

Cleveland, Ohio 44135

Under Contract DEN 3-126

for

U.S. DEPARTMENT OF ENERGY

Conservation and Solar Energy

Division of Energy Storage Systems

Washington, D.C. 20545

Under Interagency Agreement DE-Al04-80AL12726 



\section{FORWARD}

This is the final report of a preliminary design and system cost study of the Redox Energy Storage System being developed by the NASA-Lewis Research Center, Cleveland, Ohio. The work was carried out under Contract DEN3-126. Dr. Lawrence Thaller was the NASA Project Manager.

The study was carried out by Power Systems Division of United Technologies Corporation. Mr. Kenneth Michaels provided the system and component preliminary designs. Mr. Gene Hall was responsible for the system costing and financial analysis. 


\section{,}


TABLE OF CONTENTS

Section

$\underline{\text { Page }}$

I

SUMMARY

1

II

INTRODUCTION

III

500-kWh SOLAR STAND-ALONE SYSTEM

6

System Description

6

Cost Summary

9

Electrolytes and Reactants

11

Cell Stack

14

System Structure and Plumbing

26

Controls

29

Pumps

30

Manufacturing Facility

31

Financial Considerations

35

IV

100-MWh ELECTRIC UTILITY SYSTEM

37

System Description

37

Cost Summary

42

Electroytes and Reactants

44

Cell Stack

48

System Structure and Plumbing

50

Controls

54

Pumps

56

Manufacturing Facility

58

Financial Considerations

63 
TABLE OF CONTENTS (Continued)

Section

V

VI

REFERENCES $\underline{\text { Page }}$

65

67

\section{APPENDICES}

A - 500-kWh REDOX ENERGY STORAGE DESIGN PARAMATERS

B - 500-kWh CONTROLLER FUNCTION AND ACTIONS

C - 100 MWh ENERGY STORAGE SYSTEM DESIGN PARAMETERS

77

D - 100 MWh CONTROLLER OPERATING MODES

81

E - 500-kWh, 100 MWh FLOW CELL MANUFACTURING CAPITAL EQUIPMENT

85 


\section{LIST OF FIGURES}

\begin{tabular}{|c|c|c|}
\hline Figure & Title & $\underline{\text { Page }}$ \\
\hline 1 & Two-Tank Electrically Rechargeable Redox Flow Cell & 4 \\
\hline 2 & Fluid Schematic of $10 \mathrm{~kW} / 500 \mathrm{kWh}$ System & 7 \\
\hline 3 & Electrical Schematic of $10 \mathrm{~kW} / 500 \mathrm{kWh}$ System & 8 \\
\hline 4 & Cost Comparison for Tanks - 10kW/500kWh System & 14 \\
\hline 5 & $10 \mathrm{~kW} / 500 \mathrm{kWh}$ Redox System Arrangement & 16 \\
\hline 6 & Cell Stack Assembly Details & 18 \\
\hline 7 & Electrode Flow Path - 10kW/500kWh System & 19 \\
\hline 8 & Electrode Frame - $10 \mathrm{~kW} / 500 \mathrm{kWh}$ System & 22 \\
\hline 9 & Drawing of Facility Building - $10 \mathrm{~kW} / 500 \mathrm{kWh}$ System & 32 \\
\hline \multirow[t]{2}{*}{10} & A. Fluid Schematic of $10 \mathrm{~mW} / 100 \mathrm{mWh}$ System & 38 \\
\hline & B. Fluid Arrangement Around Cell Stack & 39 \\
\hline 11 & One-Line Electrical Schematic - 10mW/100mWh System & 40 \\
\hline 12 & 10mW/100mWh Redox Energy Storage System Plot Plan & 41 \\
\hline 13 & Typical Stack and Plumbing Arrangement & 47 \\
\hline 14 & Cost Comparison for Tanks - $10 \mathrm{~mW} / 100 \mathrm{mWh}$ System & 48 \\
\hline 15 & Drawing of Facility Building - $10 \mathrm{~mW} / 100 \mathrm{mkWh}$ System & 59 \\
\hline
\end{tabular}




\section{LIST OF TABLES}

Table

$\underline{\text { Title }}$

$\underline{\text { Page }}$

I System Performance and Operating Parameters - 10kW/500kWh

9

II $10 \mathrm{~kW} / 500 \mathrm{kWh}$ System Costs

III Cost of Chemicals $10 \mathrm{~kW} / 500 \mathrm{kWh}$ Solar Stand-Alone System 12

IV Cell Stack Assembly Cost - 10kW/500kWh System 20

V Material Cost For Structure and Enclosure - 10kW/500kWh System 26

VI Plumbing/Valve Schedule - 10kW/500kWh System 28

VII Make/Buy Assumption - 10kW/500kWh System 31

VIII Labor Costs - 10kW/500kWh System

IX System Performance and Operating Parameters - 10mW/100mWh 42

X $10 \mathrm{~mW} / 100 \mathrm{mWh}$ System Costs 43

XI Cost of Chemicals $10 \mathrm{~mW} / 100 \mathrm{mWh}$ Electric Utility Unit 45

XII Cel1 Stack Assembly Cost - 10mW/100mWh System 50

XIII Plumbing/Valve Schedule - 10mW/100mWh System 53

XIV Hydrogen Supply System - 10mW/100mWh System 54

XV Electrical Connectors/Cables - 10mW/100mWh System 56

$\begin{array}{lll}\text { XVI Make/Buy Split } & 58\end{array}$

XVII Labor Costs $-10 \mathrm{~mW} / 100 \mathrm{mWh}$ 


\section{SUMMARY}

The specific objectives of this contract were to establish Redox Energy Storage System conceptual production designs, estimate production cost, and establish the influence of various parameters on production cost. A conceptual design and cost estimate was prepared for each of two energy storage applications: 1) an electric utility 100-MWh requirement (10 MW for 10 hours) for energy storage for utility load leveling application, and 2) a 500-kWh requirement (10 kW for 50 hours) for use with a variety of residential or commercial applications, including stand-alone solar photovoltaic systems. The Redox cell stack design and costing received major emphasis, as this is the contractor's primary area of expertise applicable to the Redox system.

The conceptual system designs were based on cell performance levels, system design parameters, and special material costs supplied by NASA early in the study. These data were combined with established thermodynamic and hydraulic analysis to provide preliminary system designs. Estimated costs were established, based on the battery cost guidelines established by the Electric Power Research Institute (EPRI), and in-house developed techniques used in costing fuel cells for commercial application.

Results show the Redox cell stack to be amenable to mass production techniques with a relatively low material cost. Specific cost is estimated to be $\$ 12.50$ to $\$ 13.00 /$ $\mathrm{ft}^{2}$ which translated to $\$ 5.60 / \mathrm{kWh}$ for the $500 \mathrm{kWh}$ application and $\$ 13.04 / \mathrm{kWh}$ for the shorter discharge time $100 \mathrm{MWh}$ mission. In both cases the cell stack cost is a minor factor in total estimated cost.

In both applications, system cost is dominated by the cost of the reactants, electrolyte, and associated tankage. In the smaller system, with its nominal 50-hour discharge rate, 81 to $87 \%$ of the cost is in these elements. In the larger system, with a 10-hour discharge time, the percentage is lower but still a very significant 58 to $73 \%$ of the total cost. The two major elements of this cost are the chromiumchloride anode reactant and the large fiberglass tanks necessary to store the electrolytes. 
Total estimated manufacturers selling price for the 500-kWh system varies from $\$ 74$ to $\$ 116 / \mathrm{kWh}$, depending on the assumptions as to the cost of the chromic chloride reactant ( $\$ 0.032$ to $\$ 1.30$ per pound). The higher cost corresponds to present day chromium processing methods; the lower cost is based on a more direct and less costly technique proposed by NASA.

The corresponding selling prices for the electric utility 100-MWH design are $\$ 63$ to $\$ 110 / \mathrm{kWh}$. The lower price level reflects the higher cell performance assumptions for the cell stack and the lower tankage costs associated with two molar solutions rather than the one molar defined for the smaller system.

These system costs, although higher than original NASA estimates, are believed to be competitive with the battery system such as lead-acid and nickel zinc that offer similar near-term deployment potential. 


\section{INTRODUCTION}

The ability to store electrical energy is a necessity for intermittent energy sources such as windmill and photovoltaic systems. For much larger systems such as the electric utilities, storage, while not a necessity, is being given serious consideration because of potential economic advantages that storage might offer. These advantages are related to the fact that the ability to store energy economically would allow the utilities to increase their baseload capacities and load factors and use newer, more efficient, and less polluting generating equipment. Therefore, for both levels of electric power generation--intermittent (sma11) and electric utility (large) -- the economics for a given storage system is of central importance. For utilities in particular, the decision of whether to use storage will be based almost entirely on economic factors. When giving consideration to a given storage technology, three questions are immediately asked: What is the state of the technology?; From a technical standpoint, does it have attractive features?; What will it cost? The Lewis Redox energy storage system is a rapidly maturing technology, in that the major technical problems have been overcome. The system has many attractive features, the foremost among these being its high efficiency and its lack of any life-limiting characteristics. This study couples these recent technology advances with the materials of construction and costing techniques that are being established at United Technology Corporation in a closely related technology area: namely, phosphoric acid fuel cells.

The Redox Flow Battery system is a candidate for both megawatt hour level energy storage for electric utility use and for multi-kilowatt hour level storage for use with dispersed generation. The basis of the Redox system is a group of cells in which electrochemically active solutions, containing highly reversible redox couples, undergo reduction and oxidation reactions. The solutions are stored separately, as anolyte and catholyte, in bulk storage tanks. During periods of power demand, the charged solutions are pumped through the Redox Flow Battery and electrical energy is released. When power is available, the discharged solutions are again pumped through the Redox Flow Battery. Electrical energy is supplied to the cell, electrochemically regenerating or recharging the active anolyte and catholyte redox species. 
A simplified schematic diagram of the NASA-Lewis Redox system is shown in Figure 1. Representative states of charge of each couple are also shown.

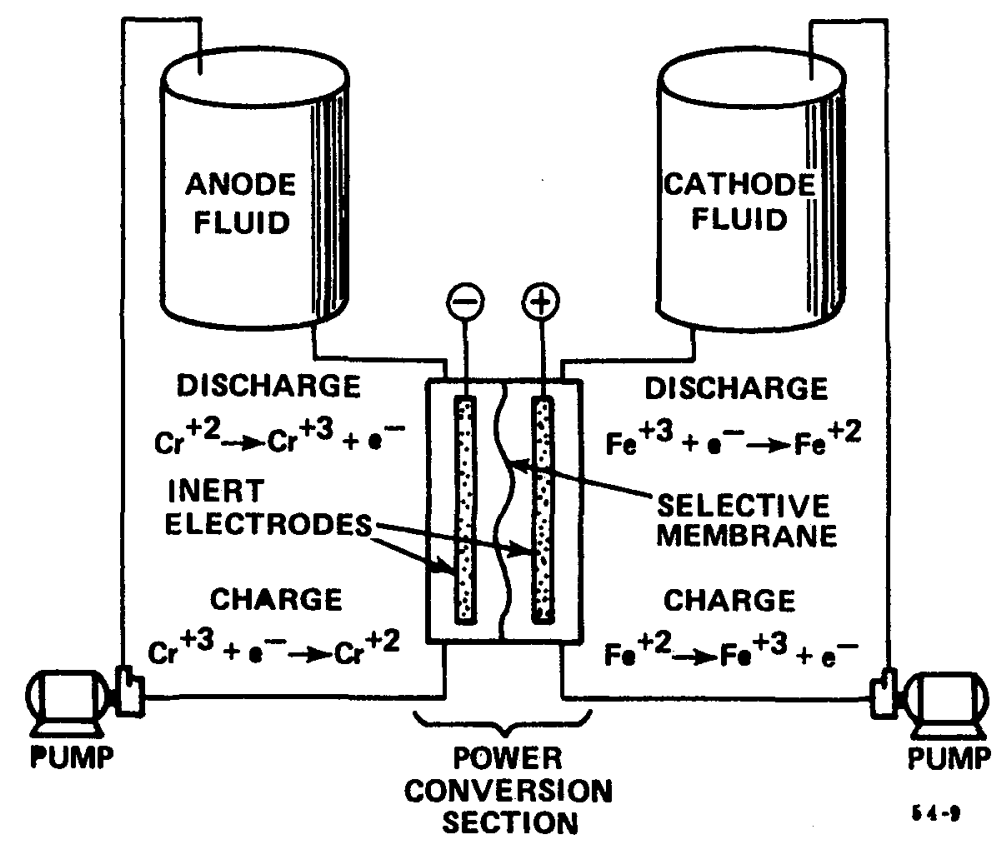

Figure 1. Two-Tank Electrically Rechargeable Redox Flow Cell

Each Redox cell consists of two compartments containing the flow anolyte or catholyte solutions and suitable inert electrodes separated by an ion-selective permeable membrane. The membrane ensures separation of the active ion species, thus minimizing an inefficient mixing or self-discharge loss mode during cell operation.

As with conventional battery systems, a complete Redox energy storage system includes suitable power conditioning equipment, if required, such as an inverter/ transformer to convert the cell discharge output dc power to ac for use by the utility grid, and a transformer/rectifier to supply the dc power required during the recharge operating mode. Appropriate manifold piping, pumps, and coolers, if needed, would complete the storage facility. 
As described in the following sections, the redox storage concept is a very appealing candidate for bulk energy storage. Its potential advantages are listed below:

- Mild operating conditions permits use of inexpensive materials.

o No known electrochemical cycle life limitations.

o No depth of discharge limitations.

- Independent sizing of system capacity and power.

o Electrochemical capacity rebalancing done on the system level.

- Various system configurations available

o Presents a minimal environmental safety hazard.

- Existence of applicable industrial technology base in fuel cell and water electrodialysis areas. 
III. 500-kWh SOLAR STAND-ALONE SYSTEM

\section{SYSTEM DESCRIPTION}

The 500-kWh Redox Energy Storage System is intended for remote stand-alone and residential applications where some other source of electrical energy such as a dispersed solar photovoltaic system is available as the primary supply. Specifically, applications in the southwestern United States are projected, but the system would also be applicable in many economically emerging nations where small, isolated communities abound.

A 500-kWh Redox Energy Storage System, consisting of a single cell-stack divided into three cell-substacks, an anolyte and a catholyte fluid loop, a hydrogen supply and a controller was chosen as the overall system configuration to be studied.

Figure 2 illustrates the component and plumbing arrangement. Each electrolyte is stored in two interconnected subgrade storage tanks. One or both of two submersible pumps, mounted from the top of one of the tanks, circulates the electrolyte through the cell stack and back to the second tank. The piping just down stream from the pumps is divided into three parallel circuits, one for each cell substack. Electrolyte flow is the same whether the system is charging or discharging. The flow through each substack is balanced by adjusting hand valves in the cell stack exit piping.

During charging, a small amount of hydrogen is evolved from the anolyte and collects in the top of the anolyte storage tank. Eventually, this side reaction results in a reduction in the usable capacity of the anolyte and, therefore, of the entire system. The hydrogen supply system provides a means of returning this hydrogen to the anolyte by reacting it, electrochemically, with the catholyte in the rebalance cell. 


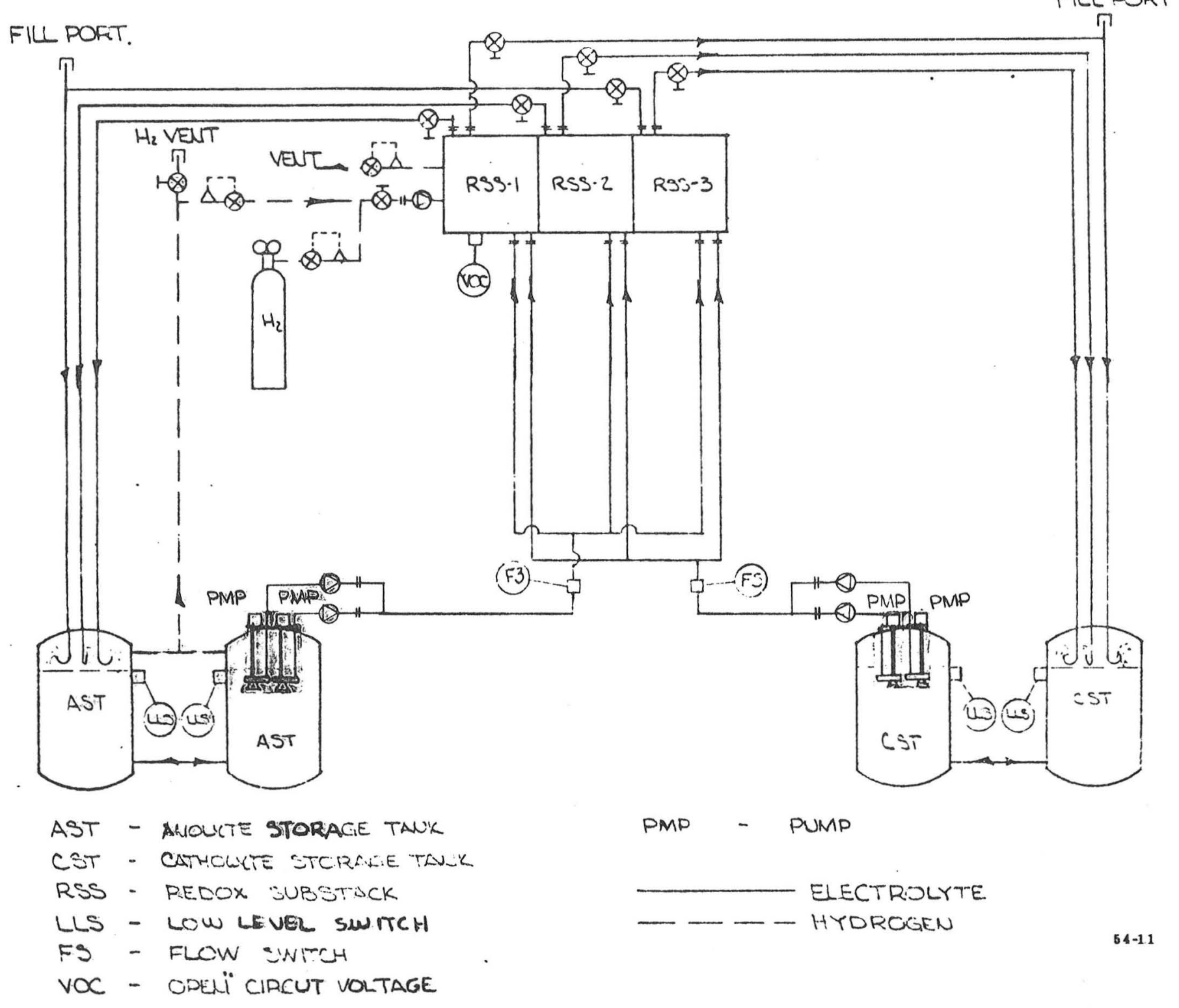

Figure 2. Fluid Schematic of $10 \mathrm{~kW} / 500 \mathrm{kWh}$ System

As shown in Figure 3, the system is arranged across the load in parallel with the photovoltaic system. Depending on the voltages, the Redox system is either charging or discharging. However, the system controller functions to fully charge or discharge the system, within the specified limits, before reversing the operation. 
The controller and electrolyte pumps are in parallel with the load and depend on power from the photovoltaic system to start. The controller is manually energized, but the pumps are energized by the controller. Voltage regulation is accomplished by the use of trim cells.

VL - line vOltage

VOC - CPEN CIRCUT VOLTAGE

R- REBALANE CEL T- TRIM CEL BANK

(No, CELS PER UNIT)

PHOTOVOLTAC ARRAY

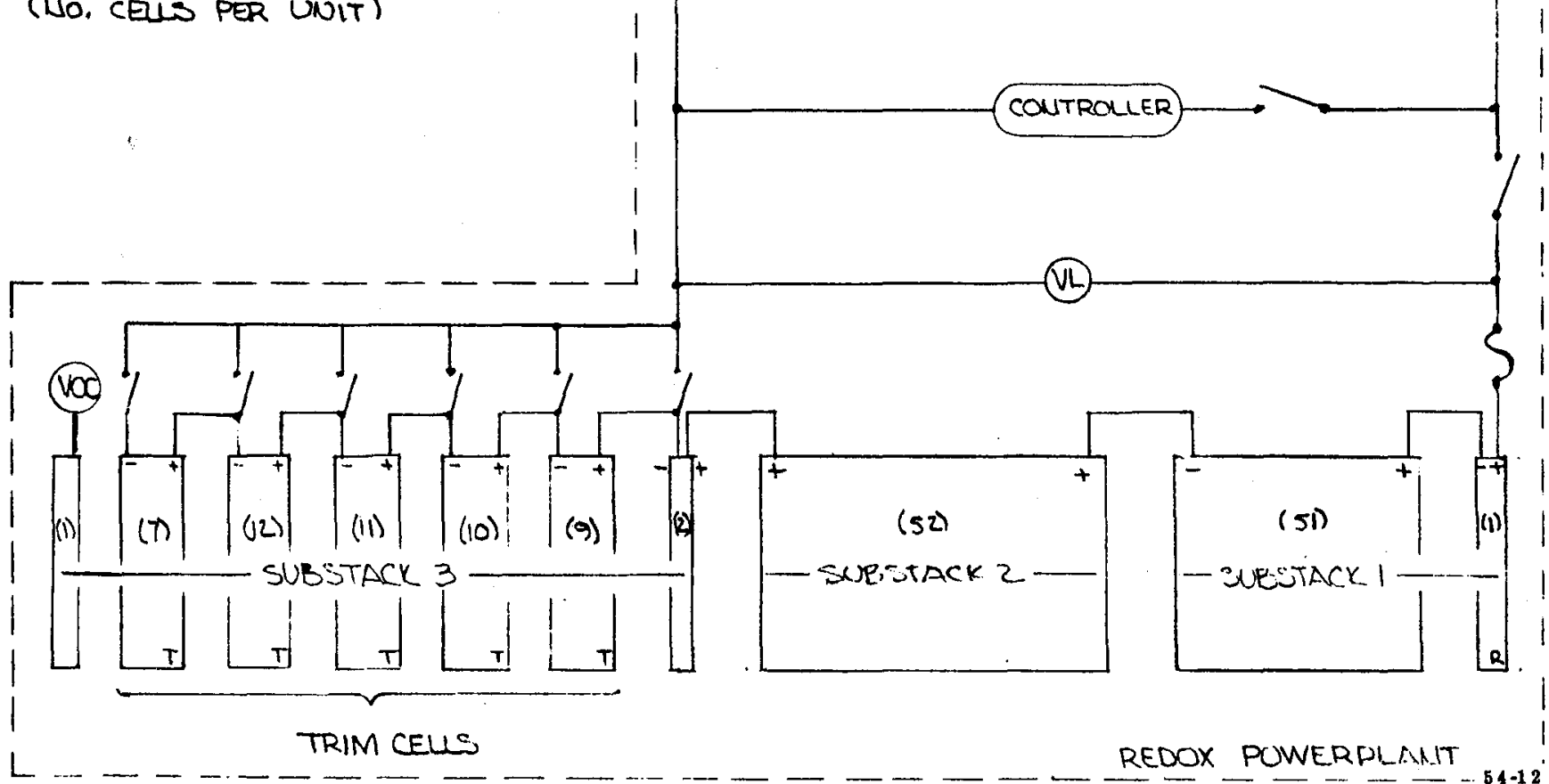

Figure 3. Electrical Schematic of $10 \mathrm{~kW} / 500 \mathrm{kWh}$ System

System performance and operating parameters for the baseline system design are listed in Table I. This system design has evolved based on a number of assumptions, guidelines, and constraints which were jointly developed by NASA and United and are listed in Appendix A. As can be seen, the design is not optimized. The 
electrolyte pumping power is much higher than desirable, indicating that a lower pressure drop and pump flow rate design is warranted. Time and funding limits precluded a redesigned system for this limited scope study.

TABLE I

SYSTEM PERFORMANCE AND OPERATING PARAMETERS $10 \mathrm{~kW} / 500 \mathrm{kWh}$

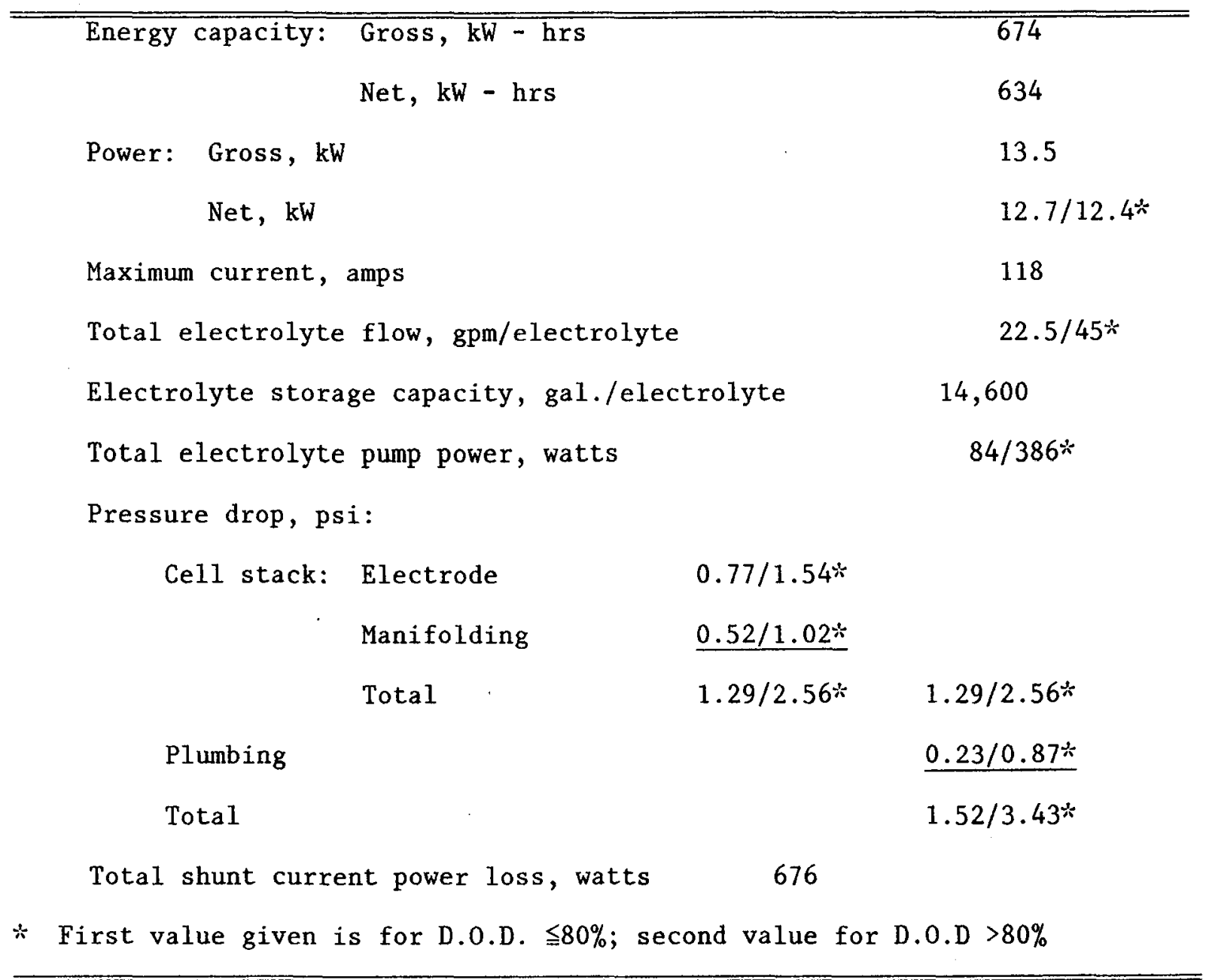

COST SUMMARY

A cost estimate for the 500-kWh Redox Energy Storage System was developed following the guidelines for estimating the capital costs of advanced battery systems prepared by A. D. Little for the Electric Power Research Institute. 
The total estimated manufacturer's selling price for this system ranges from $\$ 74 / \mathrm{kWh}$ to $\$ 116 / \mathrm{kWh}$ depending on the assumptions as to the cost of the chromic chloride reactant. The elements of the two selling prices are shown in Table II. In both cases the major system cost is that of the reactants and tankage which totals 79 to 87 percent of the total cost. All stack, balance-of-system, and business costs are small and may vary from 5 to 10 percent of the total.

A discussion of the design and an estimate for each of the major elements is contained in the following section of this report.

TABLE II. 10Wh/500kWh SYSTEM COSTS

ANNUAL PRODUCTION RATE - 1000 UNITS

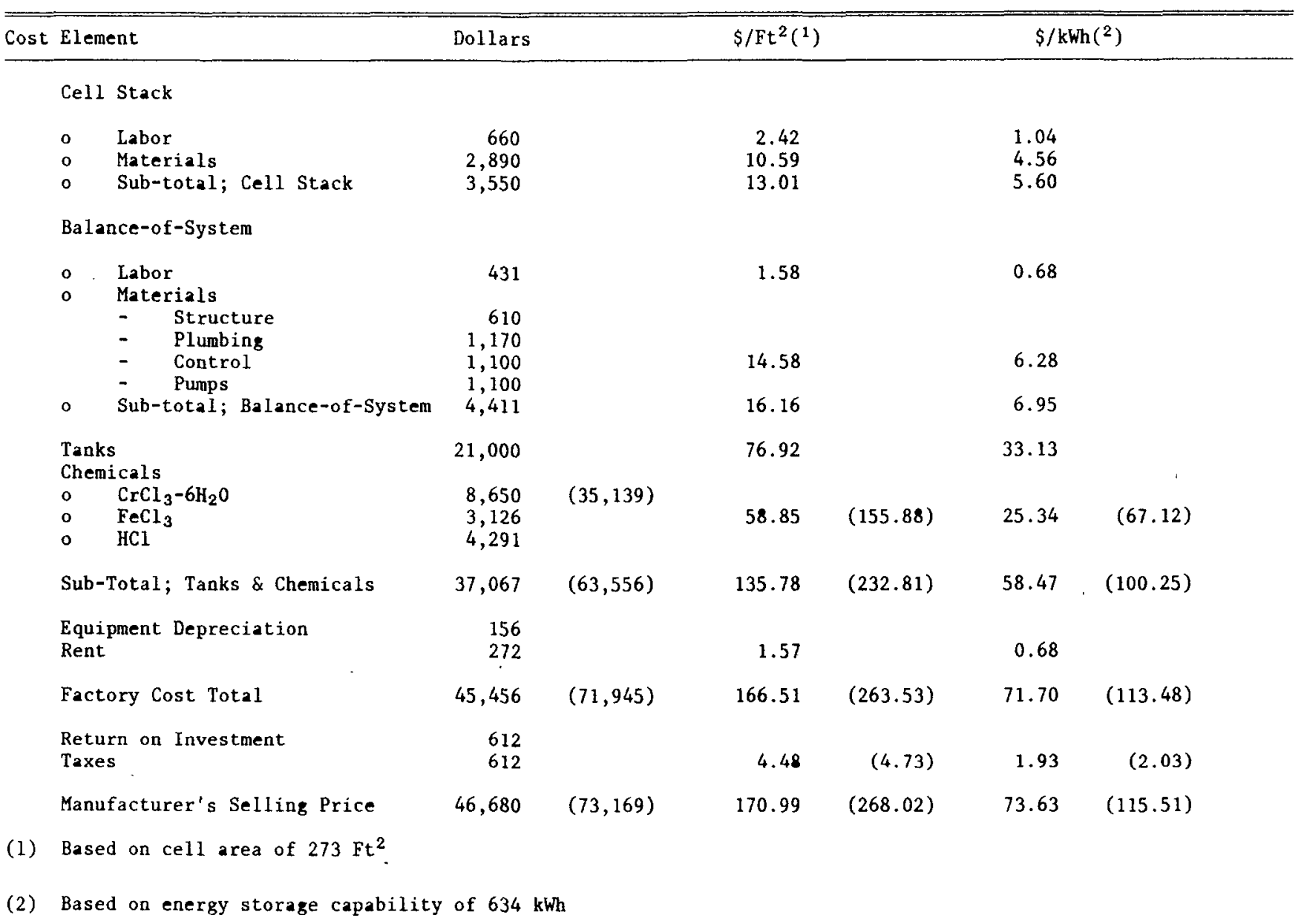




\section{ELECTROLYTES AND REACTANTS}

\section{Electrolytes}

The electrolytes employed in this design were those prescribed by the NASA. Described in the fully charged state, the anolyte is composed of $1 \mathrm{M} \mathrm{CrCl}_{2}$ supported in a $2 \mathrm{~N} \mathrm{HCl}$ aqueous solution, and the catholyte is composed of $1 \mathrm{M} \mathrm{FeC1}_{3}$ supported in a $2 \mathrm{~N} \mathrm{HCl}$ aqueous solution. In operation, the degree of charge varies between $90 \%$ and $10 \%$. Operating to such a deep state of discharge, although minimizing the quantity of electrolytes required, would impose a severe parasite power penalty if it were not for the use of a dual pump arrangement that significantly reduces that penalty when the degree of charge drops below $20 \%$.

Although the essential properties are different for each electrolyte and vary for each from the charged to discharged state, they are similar enough to permit the use of the same value for both electrolytes whether charged or discharged. These property values are listed below:

\section{Property}

Density $\left(1 \mathrm{bm} / \mathrm{ft}^{3}\right)$

Viscosity $(\mathrm{lbm} / \mathrm{ft}-\mathrm{sec})$

Electrical conductance $\left(\mathrm{ohm}^{-1}-\mathrm{in}^{-1}\right)$

Specific heat $\left(\mathrm{Btu} / 1 \mathrm{bm}-{ }^{\circ} \mathrm{F}\right)$

Thermal conductivity $\left(\mathrm{Btu} / \mathrm{w}-\mathrm{ft}-{ }^{\circ} \mathrm{F}\right)$
Value

71.

$9.06 \times 10^{-4}$

1.4554

0.8

0.384

The major portion of the electrolytes is stored in tanks external to the cell stack. The amount of each electrolyte required, and, hence, the required storage volume, is a function of the gross watt-hour capacity required of the power plant, the depth of discharge range, reduction in capacity due to permanent cross-diffusion of the electrolytic couple (taken as $25 \%$ in this design), and the average full-1oad voltage (taken as 0.9 volts at $50 \%$ D.O.D.). With these factors taken into account, the required quantity of each electrolytic solution is 12,140 gallons. In the case of chromic chloride, this translates into a requirement for 27,000 pounds as shown in Table III. NASA has defined two cost levels for this chemical of $\$ 1.30 /$ pound and $\$ 0.32 /$ pound. At these prices the per unit cost of chromic chloride varies from $\$ 8,640$ to $\$ 35,098$ or $\$ 14.65 / \mathrm{kWh}$ to $\$ 59.53 / \mathrm{kWh}$. Table III also sets forth the price 
of the ferric chloride and hydrochloric acid required for each unit. Per pound prices for these chemicals were determined from chemical trade journals. The total price of chemicals for each system varies from $\$ 27.12 / \mathrm{kWh}$ to $\$ 72.00 / \mathrm{kWh}$ depending on the chromic chloride price assumed.

TABLE III

REDOX BATTERY SYSTEM

$10 \mathrm{~kW} / 500 \mathrm{kWh}$ SOLAR STAND-ALONE SYSTEM

COST OF CHEMICALS

CHROMIC CHLORIDE $-\mathrm{CrCl}_{3} \cdot 6 \mathrm{H}_{2} \mathrm{O}$

Molecular Weights

$$
\begin{aligned}
& \mathrm{Cr}-52.01 \\
& \mathrm{C} 1-35.457 \\
& \mathrm{H}=1.008 \\
& 0-16.0 \\
& \mathrm{CrCl}_{3} .6 \mathrm{H}_{2} \mathrm{O} @ 1 \text { molaf } 266.48
\end{aligned}
$$

HYDROCHLORIC ACID - HCl

$\mathrm{H}-1.008$

$\mathrm{Cl}-35.457$

$\mathrm{HCl}-36.465$ @ 2 molaf 72.93

\section{$\underline{\text { Requirement }}$}

12,140 gallons @ 266.48 grams/liter

27,000 非 @ $\$ 1.30 /$ 非 or $\$ 0.32 /$ 非

$\$ 35,098$ or $\$ 59.53 / \mathrm{kWh} @ 1.30 /$ 非

$\$ 8,640$ or $\$ 14.65 / \mathrm{kWh} @ \$ 0.32 /$ 非

FERRIC CHLORIDE $-\mathrm{FeCl}_{3}$

$\mathrm{Fe}-55.85$

$\mathrm{Cl}-35.457$

$\mathrm{FeCl}_{3}-162.22$ @ I molar 162.22
12,140 gallons @ 162.22 grams/liter

16,435 \#利 \$0.19/非

$\$ 3,123$ or $\$ 5.29 / \mathrm{kWh}$ 
$\underline{\text { Reactant Storage }}$

The reactant tankage concept chosen for storage of the required 24,280 gallons of solution includes four, 7,500 gallon underground fiberglass storage tanks. These tank sizes allow for approximately $20 \%$ ullage and provide reasonably truck transportable units. It was decided to install the tanks below grade (below the frost line) for maximum environmental protection and to ensure that the electrolytic solutions can drain out of the cell stack and plumbing completely when the power plant is shut down. This greatly facilitates maintenance on all components except the tanks themselves, and eliminates the requirement for special supporting structures. Each pair of tanks is manifolded at the lowest point to permit the free interchange of the contents of each. Electrolyte to be delivered to the cell stack is withdrawn from one tank and returned to the other. In this way, complete mixing of the electrolyte between the two tanks is maintained at all times. The delivery outlet is situated below the lowest electrolyte level normally encountered in operation.

Selection of the tank material considered such factors as structural integrity, life, compatibility with the electrolytic solutions, and cost. Options considered included plastic-lined steel tanks and fiberglass tanks. Rubber pillow tanks were also investigated, but are obviously limited to above ground use.

\section{Cost Summary}

Discussions with tank suppliers ${ }^{\left({ }^{1}\right)}$ indicated satisfactory structural life and electrolyte compatibility characteristics for both the plastic-lined steel and fiberglass tanks. A concern in the area of life and electrolyte compatability was noted for the pillow tanks. Cost comparisons for the tank options are shown in Figure 4. The lowest cost option is a pillow tank, followed by the fiberglass tank, with the plastic-lined steel tank the most costly. It should be noted that the possibility of further cost reductions was indicated by all suppliers and could be realized with more specific purchase negotiations considering the quantity of tanks (4000 per year) required. 


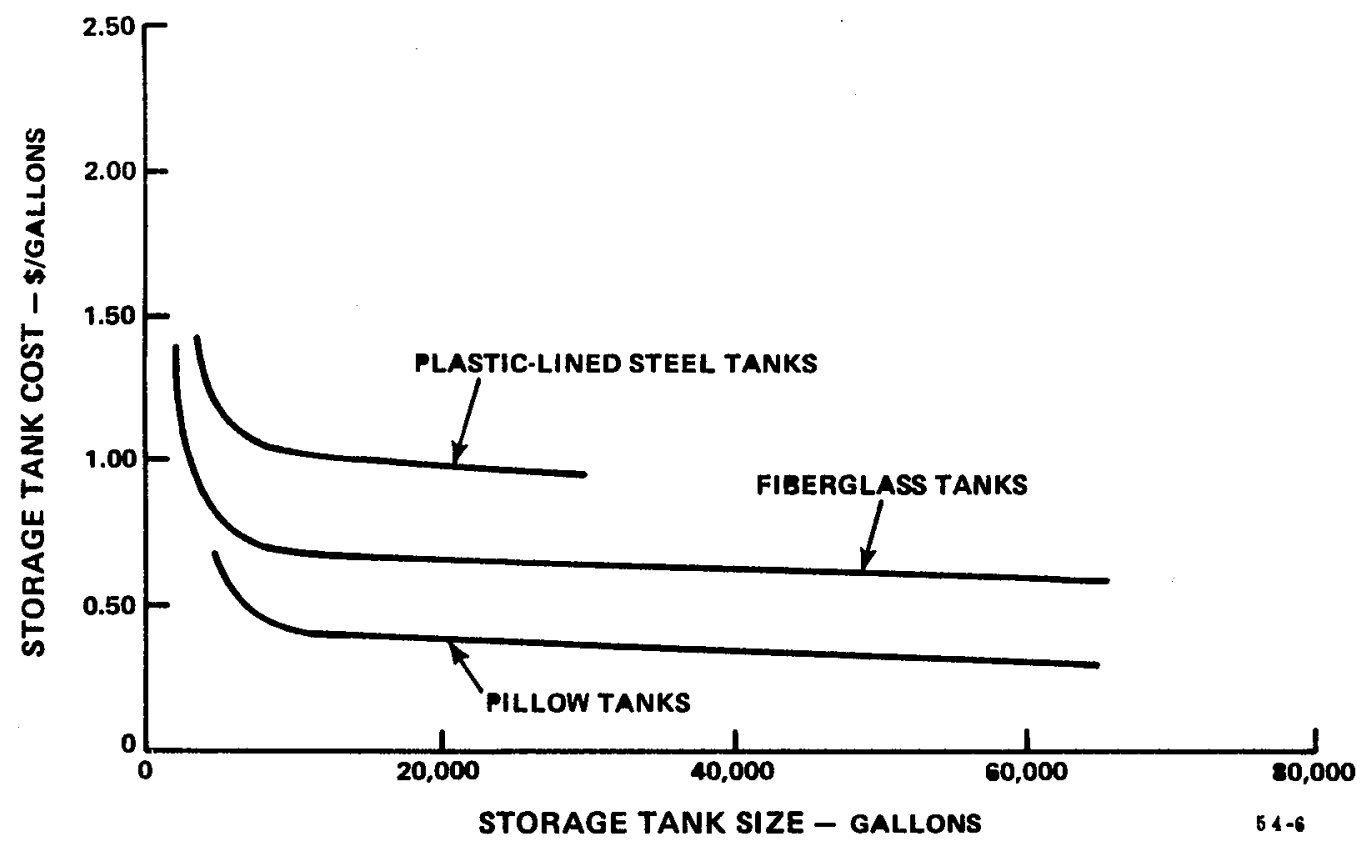

Figure 4. Cost Comparison for Tanks - 10kW/500kWh System

Based on these factors fiberglass tanks were selected for inclusion in this study. Four tanks of 7,500 gallons each are required with a diameter of 8 feet and length of 25 feet. Consistent with the cost information in Figure 4, a cost of $\$ 0.70$ per gallon was assumed. The total tankage cost per system is $\$ 21,000$ or $\$ 76.92 / \mathrm{Ft}^{2}$ of cell area and $\$ 35.57 / \mathrm{kWh}$.

CELL STACK

\section{Arrangement}

The cell stack in this design consists of 154 cells, electrically in series, plus one rebalance cell and one open circuit cell arranged in three-cell substacks of 52 cells each. 105 cells are the maximum number that can be permanently "on-line". More than that would exceed the maximum voltage of 125 volts at the highest state of charge. 154 cells are required to maintain the lowest allowable voltage of 115 volts at the lowest state of charge. The 49 cells making up the difference between these two limits are divided into five groups or "banks" and are referred to as 
trim cells. The banks of trim cells can be switched in or out of the circuit, thereby compensating for the changing state of charge of the system. Specifically, Substack 1 contains the rebalance cell, located at the far positive end to simplify the hydrogen plumbing, and 51 permanently connected cells. Substack 2 contains 52 permanently connected cells. Substack 3 contains 2 permanently connected cells, the five banks of trim cells containing 9, 10, 11, 12 \& 7 cells respectively, and the open circuit cell.

In order to reduce the shunt current loss in the internal electrolyte manifolds of the cell stack, each substack is hydraulically in parallel with the others. Thus, the maximum full-load voltage at $90 \%$ D.0.D. from one end of a manifold to the other is about 39 volts instead of 115 volts. Only through the external plumbing is the full-cell stack voltage seen, and therefore, the electrolyte resistance paths between the substacks may be made as large as desired.

As shown in Figure 5, the substacks are mounted side by side on a simple U-channel frame. The frame, $12 \mathrm{ft}$. by $2 \mathrm{ft}$., is large enough to accept the controllex and the auxiliary hydrogen supply as well. A simple insulated cover fits over the entire assembly. 


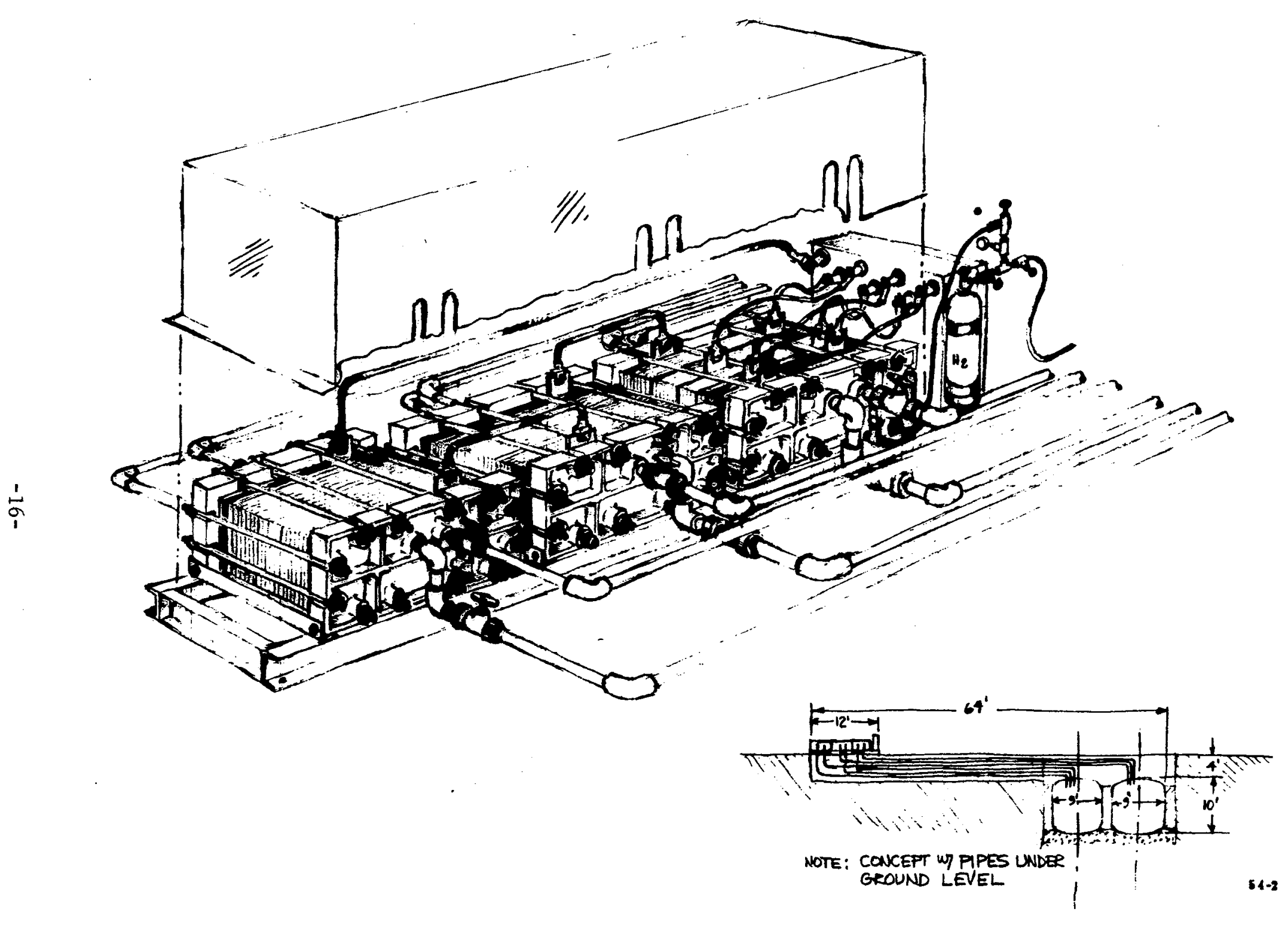

Figure 5. 10kW/500kWh Redox System Arrangement 
Cells

Each cell consists of a semi-permeable membrane sandwiched between two polyvinyl chloride (PVC) frames in a chemically bonded assembly, as shown in Figure 6. The window in either frame piece positions a carbonized felt electrode in contact with and on each side of the membrane. The frame pieces also contain the port channels that direct the flow of each electrolyte from the inlet manifolds to the electrodes and out to the exit manifolds. Two gaskets, formed with a window, surround the electrodes on either side of the frame assembly. The gaskets perform two functions: they cover the port channel area separating it electrically from the bipolar separator plates, and they prevent electrolyte leakage between the frame assembly and the bi-polar plates. The window in the gaskets permits intimate contact between the electrode and the bi-polar plate, thus establishing cell-tocell electrical continuity. Each repeating section contains a frame assembly (two-frame pieces and the membrane), two electrodes, two gaskets, and a bi-polar plate. Whenever it is necessary to tap-off current from the cell stack, a copper collector plate is substituted for the bi-polar plate.

While several elements in the cell substacks are chemically bonded together, most are not, and it is necessary to employ end plates and tie rods to hold the substacks together and seal, with the aid of the gaskets, the unbonded joints against leakage. Each end plate is cast iron and, therefore, must be separated from the actual cells by a non-conducting insulator plate.

The electrolyte flow enters the cell from an internal manifold formed by 1.5-inch diameter holes in each of the pieces comprising the repeating sections as well as the end plates, insulator plates, and collector plates. Four manifolds are provided: an inlet and exit anolyte manifold and an inlet and exit catholyte manifold. Electrolyte flows from the inlet manifold, through the inlet parts in the frame assembly to the electrode. Flow through the electrode is "edge" flow, i.e., through the electrode from edge to edge, as shown in Figure 7. Because of the relatively high pressure drop encountered with this flow arrangement, the shape is made short in the direction of flow causing a large aspect ratio. 


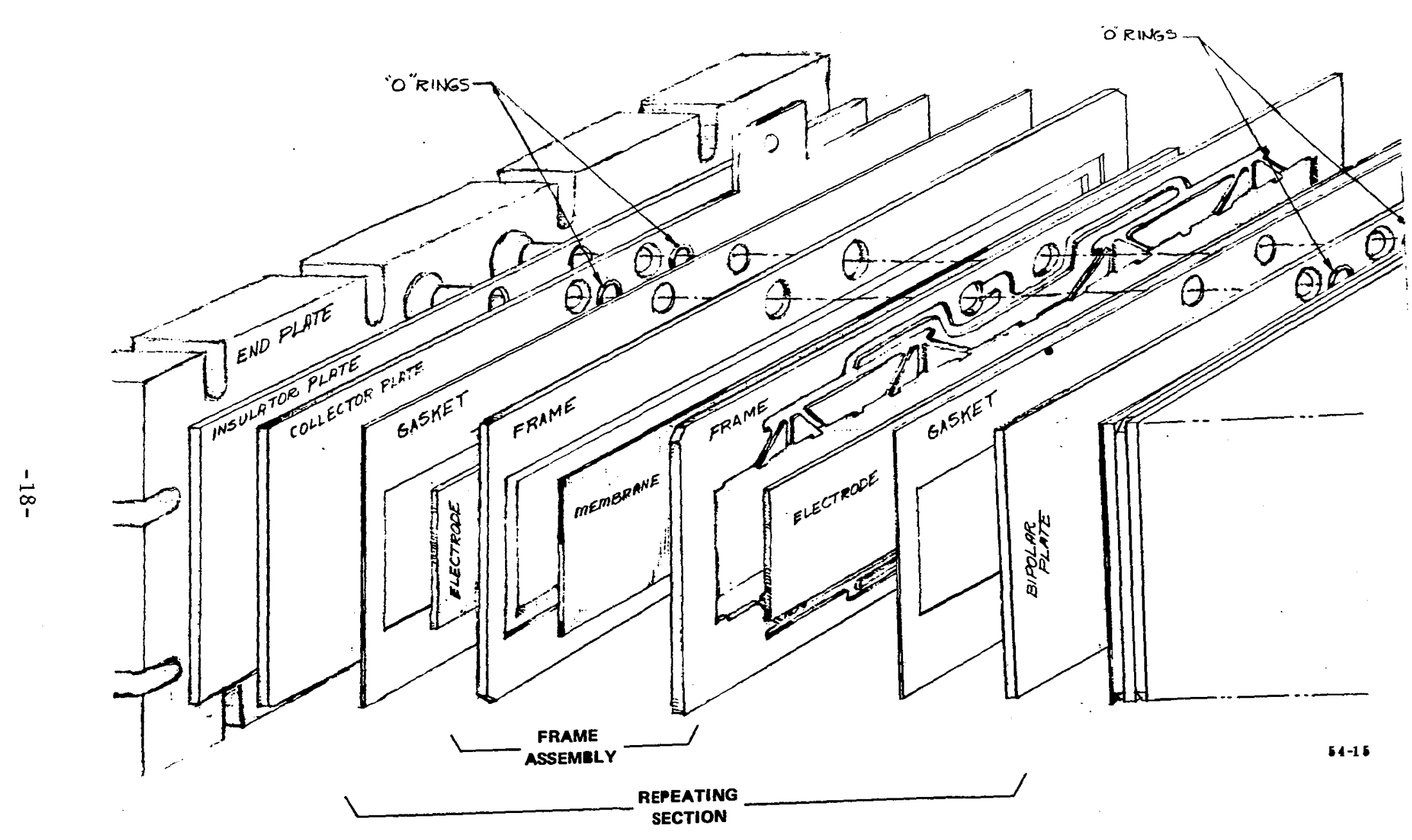

Figure 6. Cell Stack Assembly Details 


\section{EDGE FLOW}

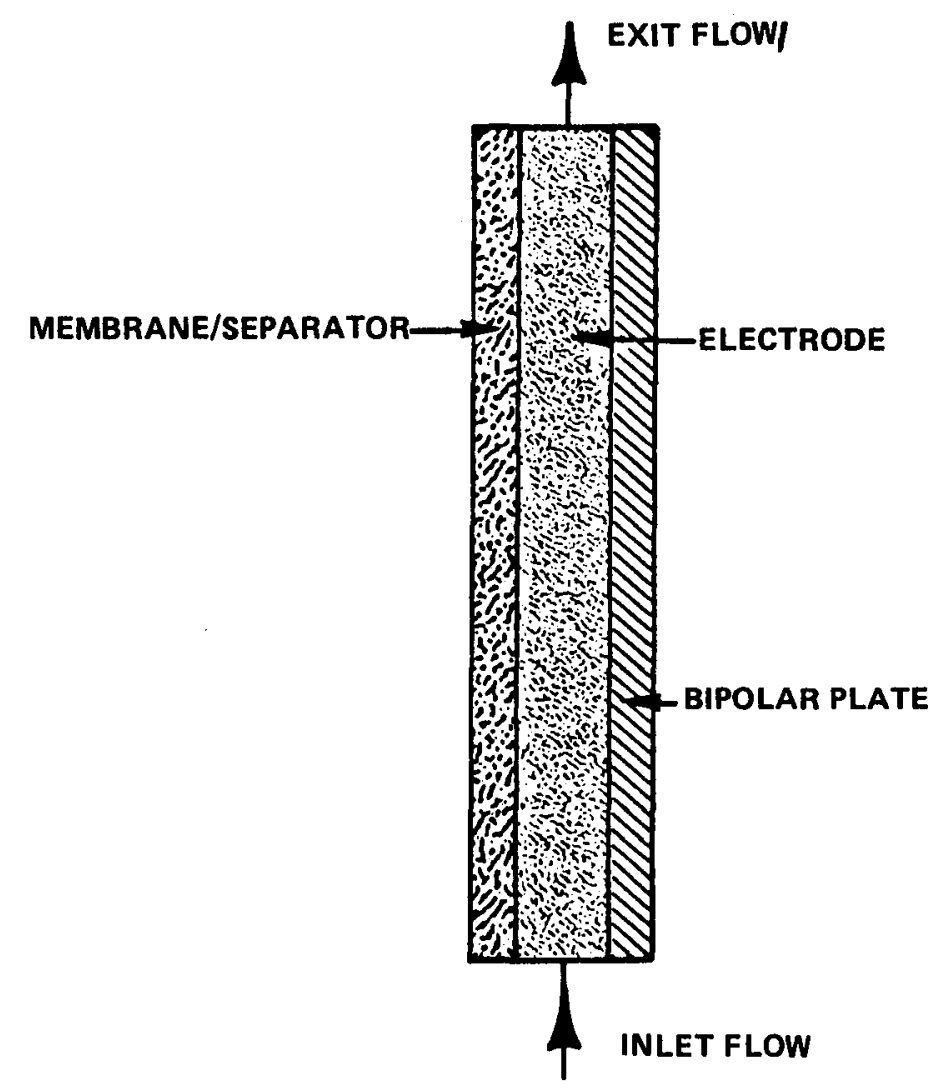

Figure 7. Electrode Flow Path $-10 \mathrm{~kW} / 500 \mathrm{kWh}$ System

To meet the performance requirements of this design, each cell has $1.75 \mathrm{ft}^{2}$ of active electrode area: 36 inches by 7 inches. Overall, the outside dimensions of the cell are 40 inches by 13 inches. The end plates are somewhat larger in planform to provide room for tie rod mounting. The thickness of a repeating section is 0.252 inches; the overall length of a substack is about 16 inches.

All the cells in the power plant are of the same configuration, including the open circuit cell and the rebalance cell. The rebalance cell is located at one end of the cell stack so that the hydrogen connections can be made easily. For this cell the end plate, insulator plate, and collector plate have two additional openings to supply hydrogen to the anolyte electrode and vent any excess away. 
The manufactured cost of this cell stack assembly varies from $\$ 3,286$ ( $\$ 5.56 / \mathrm{kWh})$ to $\$ 3,966(\$ 6.72 / \mathrm{kWh})$ depending upon the assumption for the cost of the ionic membrane. The costs for significant cost elements are listed in Table IV. Development of these costs for material are based on a mixture of NASA guidelines, vendor quotes, vendor discussions, or current prices from material cost journals.

TABLE IV

CELL STACK ASSEMBLY COST

$10 \mathrm{~kW} / 500 \mathrm{kWh}$ SYSTEM

ANNUAL PRODUCTION RATE - 1000 UNITS

\begin{tabular}{|c|c|c|c|c|c|c|c|}
\hline COST ELEMENT & $\begin{array}{l}\text { Piece Re- } \\
\text { quirement }\end{array}$ & $\begin{array}{l}\text { Pieces per } \\
\text { System }\end{array}$ & $\begin{array}{l}\text { System Re- } \\
\text { quirement }\end{array}$ & $\begin{array}{l}\text { Material } \\
\text { Unit Cost }\end{array}$ & $\begin{array}{l}\text { Material } \\
\text { Cost }\end{array}$ & $\begin{array}{l}\text { Labor } \\
\text { Cost (I) }\end{array}$ & $\begin{array}{l}\text { Total } \\
\text { Cost }\end{array}$ \\
\hline IONIC MEMBRANE & $2.06 \mathrm{ft}^{2}$ & 156 & $321 / \mathrm{ft}^{2}$ & $\begin{array}{l}\$ 2 / \mathrm{ft}^{2} \\
\text { or } \\
\$ 4 \sqrt{\mathrm{ft} t^{2}}\end{array}$ & $\begin{array}{l}\$ 642 \\
\text { or } \\
\$ 1,284\end{array}$ & -- & $\begin{array}{l}\$ 642 \\
\frac{\text { or }}{1,284}\end{array}$ \\
\hline PLASTIC FRAME & $1.72 \#$ & 312 & 537\# & $\$ 0.50 / \#$ & $\$ 269$ & $\$ 115$ & $\$ 384$ \\
\hline ELECTRODE FELT & $1.75 \mathrm{ft}^{2}$ & 312 & $546 \mathrm{ft}^{2}$ & $\$ 1.61 / \mathrm{ft}^{2}$ & $\$ 879$ & & \\
\hline $\begin{array}{l}\text { ELECTRODES } \\
\text { CATALYST }\end{array}$ & & & & & & $\$ 57$ & $\$ 1,010$ \\
\hline $\begin{array}{l}\text { GOLD } \\
\text { LEAD }\end{array}$ & $\begin{array}{r}30 / \mu_{g} / \mathrm{cm}^{2} \\
200 / \mu_{g} / \mathrm{cm}^{2}\end{array}$ & & $\begin{array}{l}0.245 \mathrm{~T} .0 \mathrm{z} \\
0.112 \text { 非 }\end{array}$ & $\begin{array}{l}\$ 300 / \mathrm{T} .0 z \\
\$ 0.25 / \#\end{array}$ & $\begin{array}{l}\$ 74 \\
\text { NEG. }\end{array}$ & & \\
\hline $\begin{array}{l}\text { BI-POLAR SEPARA- } \\
\text { TOR PLATES }\end{array}$ & $1.35 \#$ & 156 & 211 非 & $\$ 0.475 / \#$ & $\$ 100$ & $\$ 258$ & $\$ 358$ \\
\hline PLASTIC GASKET & 0.27 \# & 312 & 84\# & $\$ 0.50 / \#$ & $\$ 42$ & & \\
\hline $\begin{array}{l}\text { PLASTIC "O" } \\
\text { RINGS }\end{array}$ & & 312 & & $\$ 8 / 100$ & $\$ 25$ & & \\
\hline COLLECTOR PLATE & $31.6 \#$ & 23 & 379ㅑ & $\$ 0.85 / \#$ & $\$ 322$ & $\$ 86$ & $\$ 586$ \\
\hline INSULATOR PLATES & 3.3\# & 6 & 19.8\# & $\$ 0.50 / \#$ & $\$ 10$ & & \\
\hline END PLATES & $27.1 \#$ & 6 & $162.6 \#$ & $\$ 0.55 / \#$ & $\$ 89$ & & \\
\hline TIE RODS & $1.12 \#$ & 36 & 40.3\# & $\$ 0.30 / \#$ & $\$ 12$ & & \\
\hline $\begin{array}{l}\text { ASSEMBLY OF } \\
\text { STACK }\end{array}$ & & $\cdot$ & & & & $\$ 144$ & $\$ 144$ \\
\hline TOTAL & & & & & $\begin{array}{c}\$ 2,464 \\
\$ 3, \frac{\text { or }}{106}\end{array}$ & $\$ 660$ & $\begin{array}{l}\$ 3,124 \\
\$ 3,766\end{array}$ \\
\hline $\begin{array}{l}\text { TOTAL WITH } 95 \% \\
\text { MTL. YIELD }\end{array}$ & & & & & $\begin{array}{c}\$ 2,594 \\
\$ 3, \overline{269}\end{array}$ & $\$ 660$ & $\begin{array}{l}\$ 3,288 \\
\$ 3,964\end{array}$ \\
\hline
\end{tabular}

(1) A discussion of Labor Cost is Contained in the section "Manufacturing Facility" 
Major material cost elements include the cost of the ionic membrane and the electrode felt. Labor costs are based on a detailed facility and associated labor assessment discussed in the section "Manufacturing Facility." Labor costs total a relatively small 15 to 20 percent of the total cell stack cost. Many of the stack elements are the product of high-volume, automated production processes which tend to minimize labor costs. A brief description and cost discussion for each cell component follows.

Membrane. The heart of the Redox cell is the semi-permeable anion exchange membrane. The function of this membrane is to keep separate the two electrolytes employed while at the same time permitting charge neutralization across the membrane by allowing the negatively charged chlorine ion to pass through. A number of candidate materials made by Ionics, Incorporated, of Watertown, Massachusetts, have been tested with the most promising being a co-polymer of vinylpyridine and vinylbenzylchloride. This is applied to a synthetic woven backing and forms a membrane approximately 22 mils thick.

The membranes are cut slightly larger than the electrode size of 36 inches by 7 inches to fit in a recess in the frame around the edge of the electrode window.

The cost of the membrane has been included at two levels, $\$ 2$ and $\$ 4$ per square foot, as indicated by NASA in the basic study guidelines.

Frame. The frame pieces (see Figure 8), all identical, are molded from rigid polyvinylchloride (PVC). The overall size is 40 inches by 13 inches by 0.091 inches thick. Each frame contains a centrally located rectangular hole 36 inches by 7 inches that position the electrodes, and four 1.5 inch diameter circular manifold holes. On one side of the frame, a recess of about $11 \mathrm{mils}$ surrounds the electrode window to provide a means of holding the membrane. The ports are molded on the other side. 
FRAME CONICEPT SHOWIUC, PORTS

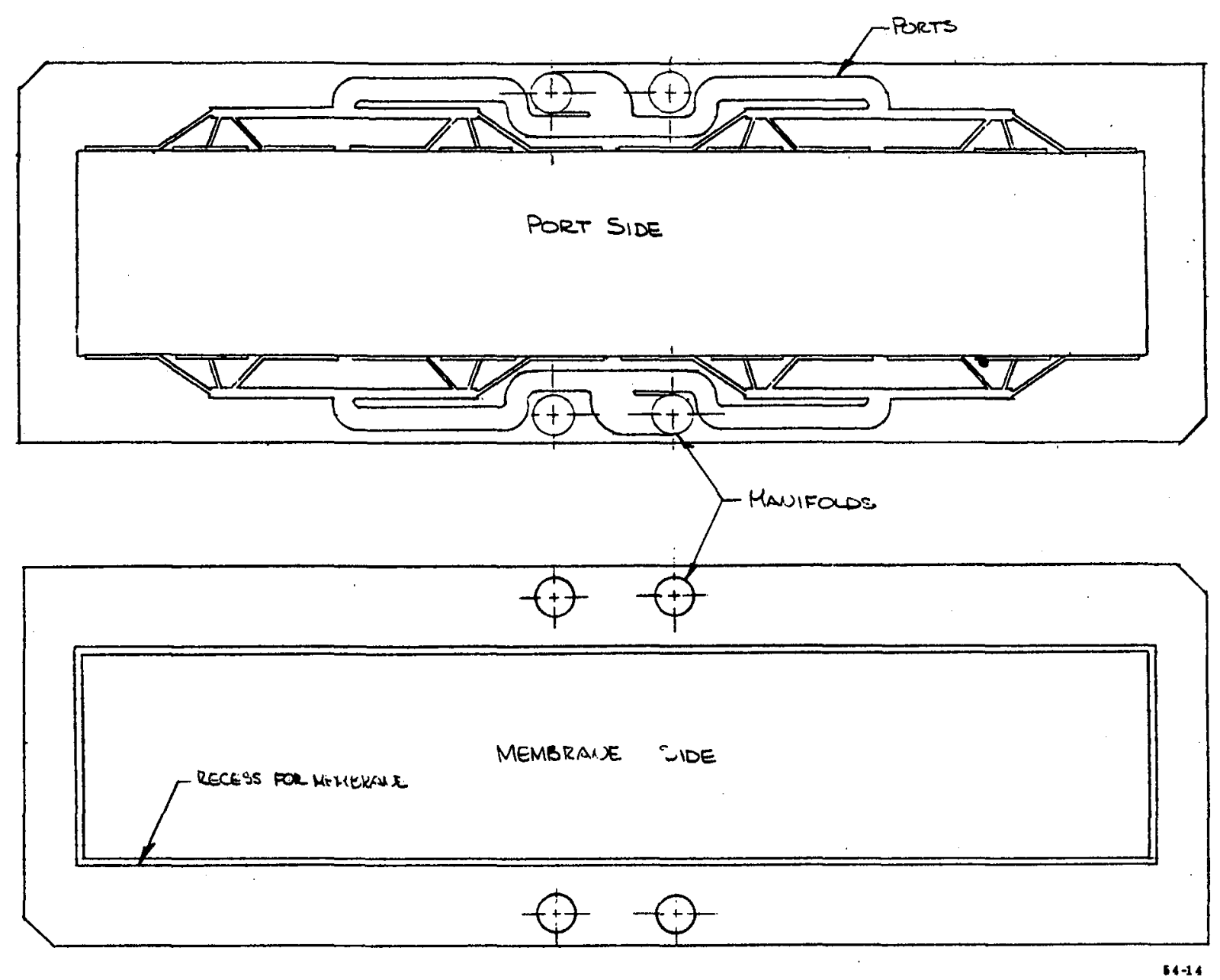

Figure 8. Electrode Frame - $10 \mathrm{~kW} / 500 \mathrm{kWh}$ System

The port pattern shown, one of perhaps several possible, was designed to minimize the combination of pumping-power shunt-current power. There are, in effect, twelve (12) ports each $125 \mathrm{mils}$ wide by $50 \mathrm{mils}$ deep. Each port has an equivalent length of about 20 inches. The inlet and exit port arrangements are identical.

With the membrane in place, the two frame pieces are joined by chemical bonding on the faces opposite the ports. This forms the frame assembly. 
The plastic frames are a significant cost item at 10 percent of the total stack cost. Material cost for an appropriate PVC resin compound suitable for manufacture of the frames by injection molding was determined to be approximately $\$ 0.50$ per pound based on discussions with a chemical supplier. (2) Labor costs are those associated with the injection molding process and are discussed in the section "Manufacturing Facility". Total plastic frame cost per stick is $\$ 384$ or $\$ 1.23$ per frame. On the basis of a system cell area of $273 \mathrm{ft}^{2}$, there is a frame cost of $\$ 1.41 / \mathrm{ft}^{2}$.

Electrodes. Each electrode is a rectangular piece of carbonized felt 36 inches by 7 inches by 0.155 inches thick in the uncompressed state. When assembled in the cell, each electrode is compressed to a thickness of only 0.100 inches. This compression assures good electrical contact between the electrode and bi-polar plate and prevents electrolyte flow leaking around the electrode. But, these advantages are achieved at the expense of reduced electrode void volume, about $90 \%$ for an uncompressed electrode as compared to about $84 \%$ for a compressed electrode, which tends to aggravate an already poor pressure drop situation.

The anode is catalyzed with $30^{\mu-\mathrm{gms}} / \mathrm{cm}^{2}$ of gold and $200^{\mu \mathrm{gms}} / \mathrm{cm}^{2}$ of lead. The cathode is not catalyzed.

The cost of the electrodes is a very significant, 25 to 30 percent, portion of the total cell stack cost. The total electrode cost per stack is $\$ 1,010$ or $\$ 3.70 / \mathrm{ft}^{2}$ of active cell area. The major portion of the electrode cost is the price of the basic carbon felt for the electrode. The basic cost of this felt is $\$ 1.61 / \mathrm{ft}^{2}$ and is based upon a cost quotation from the material supplier. (3) Catalyst costs and labor costs for the electrodes are small in comparison to the felt cost. A more efficient cell design with a higher ratio of active to total area, possibly with a low-cost plastic frame would significantly lower this cost.

Bi-polar separator plates. The bi-polar plates separate one cell from the next yet provide cell-to-cell electrical continuity. They are made of an extremely dense resin-bonded graphite which forms a rigid, impervious, non-corrosive conductor. They are pressure molded and heat cured to a thickness of $30 \mathrm{mils}$ and to the same 
outside dimensions as the frame, 40 inches by 13 inches. Because the plates are good electrical conductors, the manifold holes are slightly larger in diameter than in the other cell components to accept a dielectric insert. This reduces the shunt current power loss by limiting the shunt currents to the port channels in the frames.

The bi-polar plates are also a significant cell stack cost item and total approximately 10 percent of the total stack cost at $\$ 393$ or $\$ 1.44 / \mathrm{ft}^{2}$ of cell area. Material costs are about $1 / 3$ of the bi-polar plates total cost and reflect vendor quotations for the cost of the required graphite and resin. (4) Labor costs are significant for these items and reflect the need for several manufacturing processing steps as described in the section "Manufacturing Facility."

Gaskets. The frame gaskets are die-cut from 0.020-inch thick flexible polyvinylchloride (PVC) to the same planform dimensions as the frame, 40 inches by 13 inches outside with a 36 inch by 7 inch window. Manifold holes, 1.5 inches in diameter, are located to exactly match those in the frame.

Collector plates. At the both ends of each substack and at intermediate locations where current is to be drawn off, a tabbed collector plate is substituted for a bi-polar plate.

The collector plates are 0.188 -inch thick copper with a thin gold plating to protect them from electrolyte corrosion. They have the same planform as the bi-polar plates except for the added 1.5 inch square load tab. Just as in the case of the bi-polar plate, the collector plate manifold holes are oversized to accept a dielectric grommet to prevent shunt losses and protect against electrolyte leakage. The collector plate for the rebalance cell has two additional openings for hydrogen, 0.5 inches in diameter, which are configured in the same way.

Insulator plates. At the end of each substack, just inboard of the end plates, a PFA fluorocarbon (Teflon) insulator plate, 0.125 inches thick, prevents shorting to the cast iron end plate. The planform is, again, identical to the bi-polar plate except the manifold holes are not oversized since no grommet is necessary. 
The manifold bushings, to which the external plumbing is connected for both electrolytes and, in the rebalance cell, for hydrogen, are chemically bonded to one side of the insulator plate and protrude through enlarged mating holes in the end plate. The interior of the bushings are threaded permitting the attachment of the external plumbing.

End plates \& Tie rods. The end plates are 1.125-inch thick cast iron. They are molded with enlarged plumbing holes, as previously noted, to allow passage of the insulator plate bushings and with slots to accept the tie rods. To conserve material, the end plates are deeply formed on the exterior face, but with the necessary rigidity maintained.

Steel tie rods extend the length of the substacks from end plate to end plate and impose sufficient load to hold the substack together and prevent electrolyte leakage. Each tie rod is fitted with a follow-up device, such as a series of Belleville washers, to compensate for the plastic creep that will occur with time. At present, 12 tie rods are projected for each substack, but an exact determination of the number was not made since cost impact would be insignificant.

Electrical components. Electrical connections to the collector plates are made with a clevis-type clamp. The load cables are $2 / 0$ insulated copper cables.

The components in the above paragraphs including gaskets, collector plates, insulator plates, end plates and tie rods have been evaluated individually for material costs as shown in Table IV. Materials costs for these items have been generally based on vendor discussions or are current prices from material cost journals. Labor costs for these items have been assessed on an overall basis for the group since several of the items require similar manufacturing operations on the same equipment by the same manufacturing personnel. Total cost for these items is $\$ 586$ per cell stack with the major cost item in the group being the cost of the copper collector plates at $\$ 322$ per cell stack. 


\section{SYSTEM STRUCTURE AND PLUMBING}

The 500-kWh system consists basically of a cell stack unit, reactant tankage located at some distance from the cell stack, and interconnecting piping.

The 500-kWh system structure, as considered in this study, is the framework and enclosure associated with the cell stack. The framework is a simple, welded steel channel structure which supports the three cell substacks and provides mounting space for the control unit and the auxiliary hydrogen supply. An all-weather enclosure has been included in the design to provide protection for the unit from weather or other hazards.

The material cost for the structure and enclosure totals $\$ 642$ per unit as noted in Table V.

\section{TABLE $V$}

MATERIAL COST FOR STRUCTURE AND ENCLOSURE

$(10 \mathrm{~kW} / 500 \mathrm{kWh}$ System)

\begin{tabular}{|c|c|c|c|}
\hline Cost Element & $\begin{array}{l}\text { Material } \\
\text { Unit Cost }\end{array}$ & $\begin{array}{l}\text { Material } \\
\text { Cost } \\
\end{array}$ & $\begin{array}{l}\text { Material Cost } \\
\text { @95\%yield非 } 110 / \mathrm{H}\end{array}$ \\
\hline $\begin{array}{l}\text { - Base and Support Structure } \\
\text { 190非 of Steel per System }\end{array}$ & $\$ 0.21 /$ 非 & $\$ 40$ & $\$ 46$ \\
\hline $\begin{array}{l}\text { - Enclosure } \\
126 \mathrm{ft}^{2} \text { per System }\end{array}$ & $\$ 4.09 / \mathrm{Ft}^{2}$ & $\$ 515$ & $\$ 596$ \\
\hline - Total; Structures \& Enclosure & & $\$ 555$ & $\$ 642$ \\
\hline
\end{tabular}

The electrolyte plumbing delivers the electrolytes from the storage tanks to the cell stack and back again. The plumbing must be a dielectric, chemically inert when exposed to the electolyte and sized to provide a minimum pressure drop with minimum shunt current losses. It must also provide uniform flow to each of the three cell substacks that comprise the cell stack. 
Rigid polyvinyl/chloride (PVC), readily available from a number of sources in pipe and a wide variety of fittings and valves, was selected as the plumbing material. It is in general use by the chemical industry for handling corrosive, acidic materials, and it has shown itself to be unaffected in such service. Furthermore, it is thermally stable in the temperature range anticipated in this design.

The problem of power loss due to shunt currents in the external piping between cell substacks is minimized by separating both the supply and return lines to each cell substack as near to the storage tanks as possible and then selecting both pipe length and diameter by optimizing the combined pump and shunt current power loss. This led to a length from the pump exit manifold to the cell stack of 20 feet with a pipe diameter of 1.5 inches. The pipe size upstream of the manifold to the storage tanks of 2.5 inches was selected to give nearly the same mass velocity throughout the plumbing system.

Trim valves are provided at the cell stack in the electrolyte return lines to permit balancing the flow to each cell substack after installation. While small flow variation may be tolerated by the system, any significant variation would have a marked effect on performance. Couplings are provided in the supply line at the pump exit and at the cell substacks, and in the return line at the cell substacks. These couplings permit removal of the cell stack or the pumps without major plumbing involvement.

PVC components for the reactant supply system were selected from vendor catalogs $(5)$ and are listed in Table VI. Unit prices reflect current vendor catalog prices with appropriate discount for quantities required for production of 1000 systems per year. Total reactant supply system cost is $\$ 723$ or $\$ 1.23 / \mathrm{kWh}$.

Hydrogen is supplied to the rebalance cell from the anolyte storage tank or, if required, from an on-site auxiliary hydrogen supply. Hydrogen plumbing is composed of flexible polyvinyl tubing, PVC valves, and three standard brass gas pressure regulators. 
The first gas pressure regulator acts to release hydrogen from the anolyte storage tank to the rebalance cell based on storage tank $\mathrm{H}_{2}$ pressure. The upper $\mathrm{H}_{2}$ pressure in the rebalance cell is controlled by a vent pressure regulator and the low $\mathrm{H}_{2}$ pressure is controlled by the pressure regulator in the auxiliary $\mathrm{H}_{2}$ supply. In this way, the rebalance cell is ensured of enough hydrogen without the danger of overpressuring the cell.

Hydrogen supply system components listed in Table VI were also selected and priced in accordance with current vendor catalogs. Total hydrogen supply system cost is $\$ 341$ or $\$ 0.58 / \mathrm{kWh}$.

TABLE VI

PLUMBING/VALVE SCHEDULE

$10 \mathrm{~kW} / 500 \mathrm{kWh}$ System

\begin{tabular}{|c|c|c|c|c|}
\hline & Cost Element & $\begin{array}{l}\text { Quantity } \\
\text { Per System }\end{array}$ & $\begin{array}{l}\text { Unit } \\
\text { Price } \\
\end{array}$ & $\begin{array}{l}\text { Cost Per } \\
\text { System } \\
\end{array}$ \\
\hline \multicolumn{5}{|c|}{ REACTANT SUPPLY SYSTEM } \\
\hline o & PVC Schedule 40 Pipin: & $440 \mathrm{ft}$. & $\$ 0.70 / \mathrm{ft}$ & $\$ 312$ \\
\hline o & PVC Single Union Valves & 14 & $\$ 20.00$ & $\$ 280$ \\
\hline 0 & PVC Anzle Valves & 2 & $\$ 10.40$ & $\$ 21$ \\
\hline 0 & PVC Socket Elbow & 48 & $\$ 1.40$ & $\$ 67$ \\
\hline$\circ$ & PVC Socket Tees & 4 & $\$ 1.80$ & $\$ 7$ \\
\hline$\circ$ & PVC Female Adaptor & 2 & $\$ 1.30$ & $\$ 3$ \\
\hline 0 & PVC Flange & 6 & $\$ 5.50$ & $\$ 33$ \\
\hline \multicolumn{4}{|c|}{ SUB-TOTAL; REACTANT SUPPLY SYSTEM } & $\$ 723$ \\
\hline \multicolumn{5}{|c|}{ HYDROGEN SUPPLY SYSTEM } \\
\hline o & Flexible Tube; $1 / 2$ Inch & $60 \mathrm{ft}$. & $\$ 0.75 / \mathrm{ft}$ & $\$ 45$ \\
\hline 0 & Check Valve & 1 & $\$ 29.00$ & $\$ 29$ \\
\hline$\circ$ & Metering Valve & 2 & $\$ 55.00$ & $\$ 110$ \\
\hline $\mathbf{o}$ & Shut-off Valve & 1 & $\$ 18.00$ & $\$ 18$ \\
\hline$\circ$ & Vent Valve & 2 & $\$ 30.00$ & $\$ 60$ \\
\hline$\circ$ & Tees/Nipples & & & $\$ 24$ \\
\hline$\circ$ & Connectors & 5 & $\$ 5.50$ & $\$ 28$ \\
\hline o & Pressure Gaze & 1 & $\$ 27.00$ & $\$ 27$ \\
\hline SUB-TOT & ; HYDROGEN SUPPLY SYSTEM & & & $\$ 341$ \\
\hline TOTAL; & LUM ING/VALVES & & & $\$ 1,064$ \\
\hline
\end{tabular}




\section{CONTROLS}

The power plant is designed for automatic, unattended operation after start-up. The start function, however, is manual and requires an external electrical supply. Once started, the control requirements for the system are relatively simple. The inputs consist of eight contact inputs and two voltage inputs. The outputs consist of approximately nine contact outputs and five annunciator lights. Sequencing requirements are minimal.

Three possible approaches were considered: 1) a micro-processor based control, 2) a programmable controllers, and 3) dedicated hard-wired logic. The technical requirements can easily be satisfied by any one of the three approaches. The capabilities of a micro-processor and that of a programmable controller far exceed the requirements of this application. Given a production requirement of 1000 units, it is estimated that a micro-processor based control would cost $\$ 2,000$ to $\$ 5,000$ each. A control based on a programmable controller was estimated to cost approximately $\$ 1,000$ to $\$ 2,000$; a system based on a dedicated design using hardwired logic is estimated to cost $\$ 400$ to $\$ 800$.

A control system based on a dedicated design with hard-wired logic has been selected and included in the system cost estimate. A total controller cost of $\$ 1,000$ per unit has been included to reflect the cost of:

- Dedicated electronic logic cards.

o A control cabinet with controls/gages for system operation

- Associated wiring/cables

A detailed listing of control functions and controller actions is included in Appendix B. 
PUMPS

Each electrolyte flow loop contains two pumps in parallel. One pump handles 22.5 gpm with a pressure rise of $1.5 \mathrm{psi}$ when operating alone at depths-of-discharge less than $80 \%$. When the depth-of-discharge exceeds $80 \%$, the second pump is energized. Both pumps, operating together, handle $45 \mathrm{gpm}$ with a pressure rise of 3.4 psi. All parts of the pump exposed to the electrolyte must be constructed of materials non-corrosive in the electrolyte or coated with such materials. Furthermore, the pumps must be self-priming or located in such a manner as to preclude the need for priming.

Submersible, centrifugal pumps in the capacity-head range mentioned above and not requiring priming by virtue of their submersibility, are readily available in polyvinyl chloride (PVC) or other suitable materials at reasonable cost. The cost of such pumps is in $\$ 300$ to $\$ 500$ range. Considering the quantity of pumps required (4000 units/yr), the assumption of a quantity discount is reasonable and a unit pump cost of $\$ 250$ has been assumed for this study. With four pumps for each system, pump costs total $\$ 1,000$ or $\$ 1.69 / \mathrm{kWh}$. Although normally supplied with ac motors, dc motors are also generally available to meet the Redox system requirements. The efficiency of such pump-motor combinations in this size range is not particularly high: $30 \%$ to $35 \%$, representing the best available short of developing and employing a special design that would greatly add to the cost. For this study, a combined pump-motor efficiency of $35 \%$ was used which led to a pump power requirement of 386 watts when the depth-of-discharge is greater than $80 \%$ and 85 watts when the depthof-discharge is less than $80 \%$.

Each pump is mounted from a mounting plate located on the top side of the buried tank with the motor extending above the plate into an equipment pit, and the pump housing and impeller extending down into the tank below the lowest electrolyte level normally encountered. Access to the pump-motor assembly is gained from the equipment pit through a grade-level manhole. The whole assembly can be withdrawn from the tank for easy maintenance. 
The pump mounting plate must be designed in such a way as to permit a gas-tight seal to be maintained between the tank and pump assembly in order to prevent the escape of hydrogen from the anolyte storage tank. Furthermore, it will be necessary to take special precautions to prevent an explosive mixture of hydrogen from existing in the equipment pit over the anolyte storage tank at all times, but particularly during maintenance activities.

\section{MANUFACTURING FACILITY}

A manufacturing facility layout has been developed for the 500-kWh System based on the assumption of an annual production rate of 1000 units and the make/buy split shown in Table VII. The facility envisioned is a 54,500 square foot building which is shown in Figure 9. The facility includes major areas for the manufacture of cell stack and structural components, assembly of cell stacks and the complete unit, storage of raw materials and purchased parts, shipping of finished units, and supporting office and service areas. The facility would operate primarily on a one shift basis and employ 38 personnel directly in manufacturing and assembly operations. As assessment of the production equipment requirements indicates an equipment investment of $\$ 1,250,000$. Consistent with the basic cost study guidelines which include a facility space rental charge of $\$ 5$ per square foot and 10 year straight line equipment depreciation rate the resulting unit costs are $\$ 272 /$ unit for space and $\$ 125 /$ unit for equipment.

TABLE VII

MAKE/BUY ASSUMPTION

$10 \mathrm{~kW} / 500 \mathrm{kWh}$ System

\section{MAKE}

- Cell Stack Components (except ionic membrane)

- Structure/Plumbing

- Power plant Assembly

\section{BUY}

- Ionic Membrane

- Electronic/Electrical Components

o Pumps

- Electrolyte Storage Tanks

- Electrolytes 


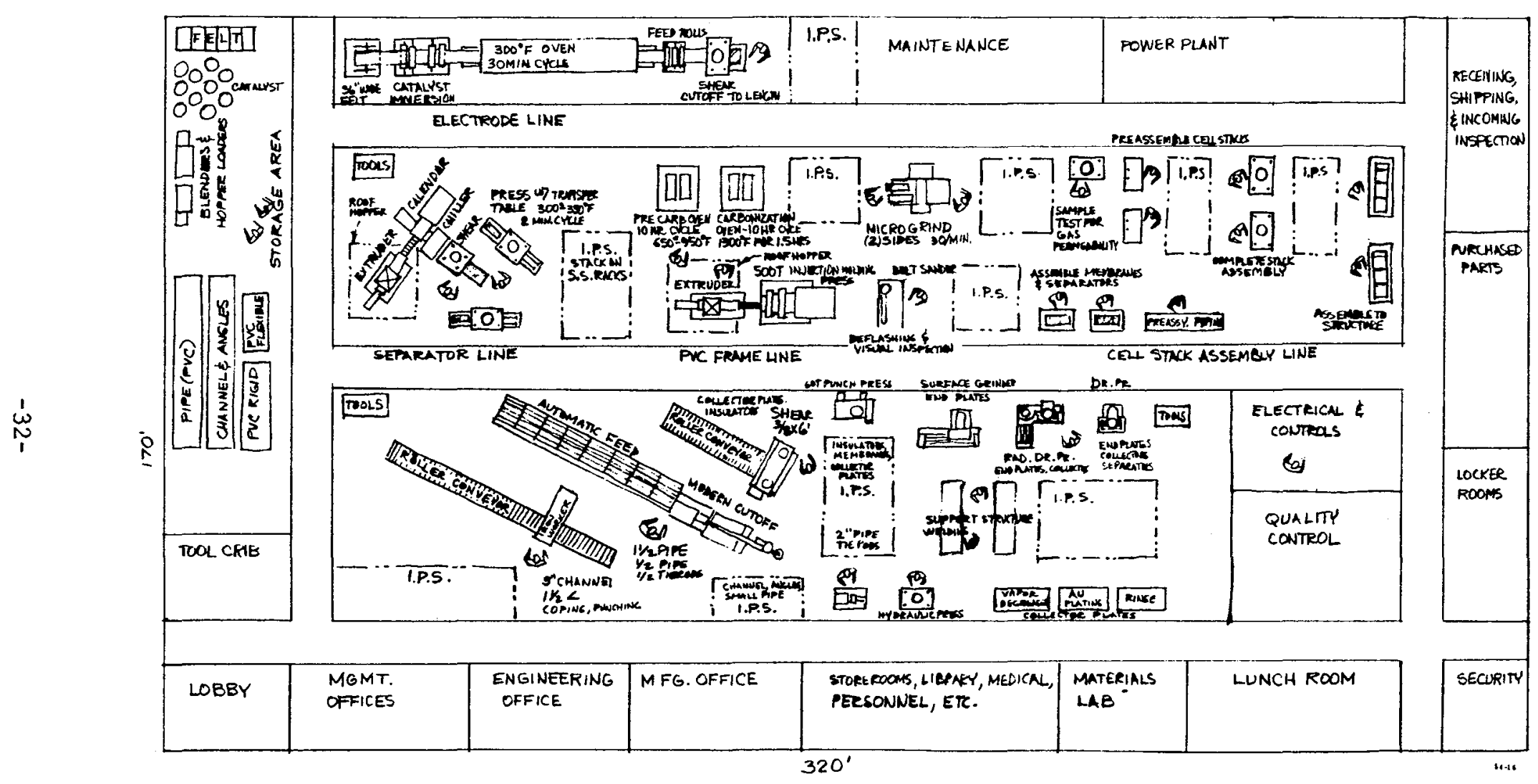

Figure 9. Drawing of Facility Building $10 \mathrm{~kW} / 500 \mathrm{kWh}$ Sytem 
The manufacture of cell stack components reflected in Figure 9 include the making of cell related parts including electrodes, bi-polar plates, plastic forms and stack related parts including end plates, tie rods, collector plates, and insulators.

Electrode manufacture assumes the purchase of the basic carbon felt in large rolls. The carbon felt strip is then drawn continuously through an immersion tank for catalyst application and through a continuous $300^{\circ} \mathrm{F}$ oven for a 30 -minute electrode heat treatment. The continuous electrode strip is then cut to proper size and stored for later use in the cell stack assembly. Overall electrode production rate is 2 pieces per minute or an annual capacity of 240,000 per shift. Total annual electrode requirement for 1000 units is 312,000 and requires a two-shift operation in this area. Electrode production is anticipated to be a very automatic operation with one man required for operation. At this level of staffing electrode production labor cost becomes $\$ 0.21 / \mathrm{ft}^{2}$ of $\$ 0.09 / \mathrm{kWh}$ as shown in Table VIII.

Bi-polar plate production involves several manufacturing operations including mixing of the graphite powder and phenolic resin, extruding, calendaring and cutting the blank plates, hot pressing the blank plates, heat treating operations, microgrinding to finish dimensions, and a gas permeability test. In order to supply the required 156,000 plates, a mix of one- and two-shift operations is necessary. A total of nine men are involved in bi-polar plate production resulting in a labor cost of $\$ 0.95 / \mathrm{ft}^{2}$ or $\$ 0.44 / \mathrm{kWh}$ also shown in Table VIII.

Manufacture of the plastic frames is accomplished in a large injection molding press at a rate of two frames per minute. In addition to the press a belt sander is provided for removal of minor plastic flashing following the molding process. Two men on a two-shift basis are required for this operation resulting in a labor cost of $\$ 0.42 / \mathrm{ft}^{2}$ or $\$ 0.19 / \mathrm{kWh}$.

Stack related parts including end plates, tie rods, collector plates and insulators are manufactured by three men on a one-shift basis utilizing a variety of machine tools. The labor costs associated with these parts total $\$ 0.32 / \mathrm{ft}^{2}$ or $\$ 0.14 / \mathrm{kWh}$. 
TARLE VIII

REDOX IATTERY SYSTEM; LALOR COSTS - $10 \mathrm{~kW}$ SOLAR STAND-ALONE SYSTEM - 156 CELLS; $1.75 \mathrm{Ft}^{2} / \mathrm{CLLL} ; 273 \mathrm{Ft}^{2} 10 \mathrm{~kW} / 500 \mathrm{kWh} ; 1000 \mathrm{UNTS} / \mathrm{YR}$.

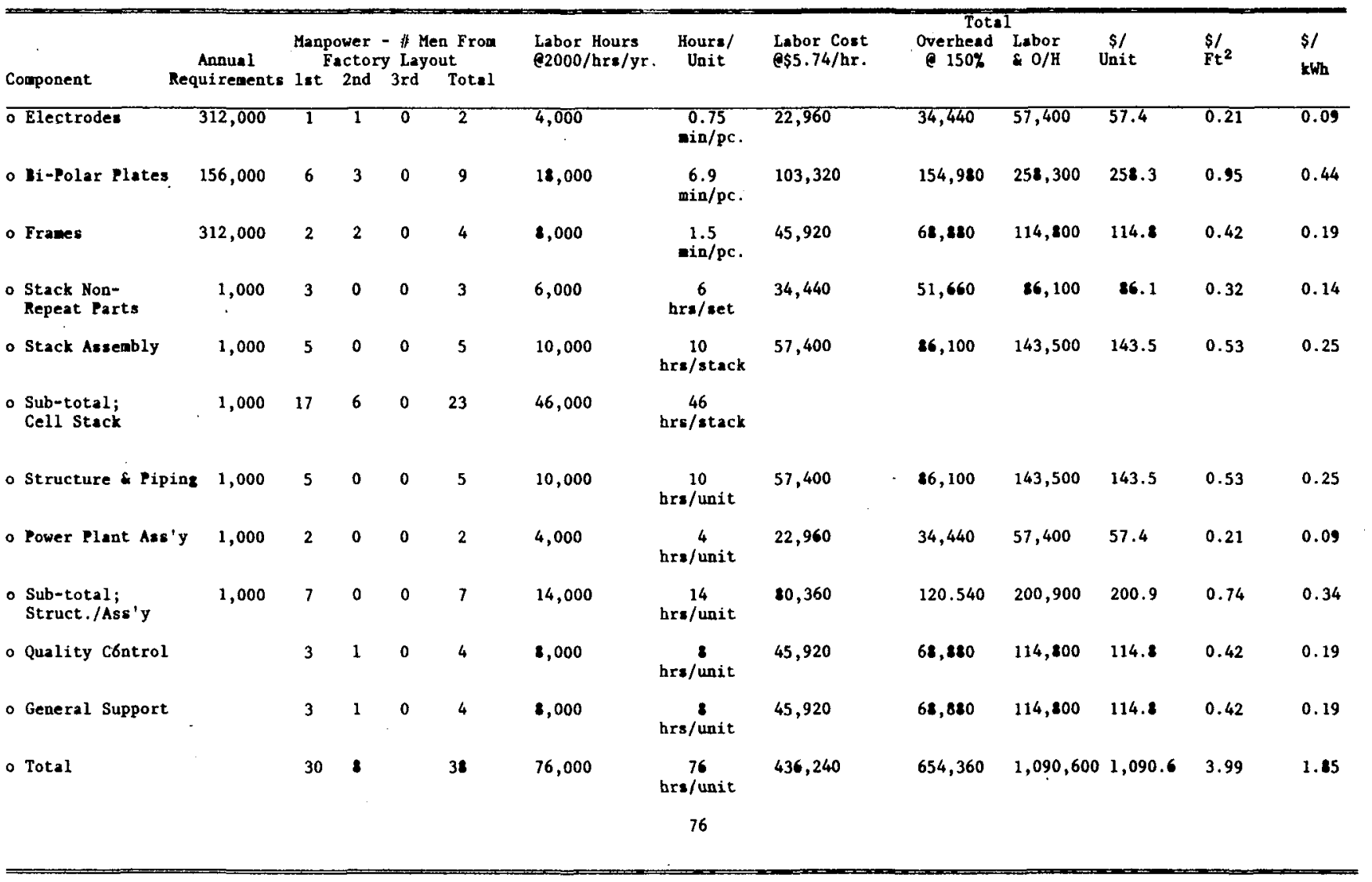

Assembly of the cell stacks is carried out in three separate operations beginning with the bonding of the ionic membrane and the two plastic frames. Following this step, electrodes, bi-polar plates and plastic frames are laid up into 56 cell stacks. In the final assembly step, the stack related parts are added to the 56 cell stacks. The stacks are then ready for installation on the power plant structure. Stack assembly is a one-shift operation utilizing a total of five men. Stack assembly labor costs total $\$ 0.53 / \mathrm{ft}^{2}$ or $\$ 0.25 / \mathrm{kWh}$.

Manufacture of the power plant components reflects the cutting of structural members and welding of the basic frame, cutting of all PVC piping to size for later assembly at the installation site, preparation of electrical controls and wiring, and preassembly of some piping for attachment to the power plant. These elements 
are then combined with the cell stack assemblies to form the final power plant. assembly. The steps require seven men on a one-shift basis and result in a labor cost of $\$ 0.74 / \mathrm{ft}^{2}$ or $\$ 0.34 / \mathrm{kWh}$.

A total of eight quality control and general support personnel are required in the facility. Production workers total 30 on the first shift and 8 on the second shift for a total of 38 men and an overall labor cost of $\$ 1091$ per unit. $\left(\$ 3.99 / \mathrm{Ft}^{2}\right.$ or $\$ 1.85 \mathrm{kWh})$.

The equipment shown in Figure 9 is listed in Appendix E, with its anticipated cost which totals $\$ 1,250,000$. Cost information is based on a number of contacts with industrial equipment suppliers.

\section{FINANCIAL CONSIDERATIONS}

Financial considerations to be discussed in this section include the areas of return on investment and taxes. Taxes are a straightforward matter since the cost study guidelines define taxes as being equal to return on investment. The discussion then centers on return on investment.

Return on investment is defined by the cost study guidelines as 15 percent of the manufacturing equipment investment plus necessary working capital. The equipment requirements and associated investment for the 1000 units per year were discussed in the section "Manufacturing Facility." Total equipment investment was determined to be $\$ 1,562,500$.

Working capital is further defined by the cost study guidelines as 30 percent of the annual factory output costs noted below:

- Labor
- Materials and Purchased Components
O Overhead
o Equipment Depreciation
$\circ \quad$ Rent


These costs are straightforward for this sytem with the exception of the classification of the costs for reactants and tankage. It has been assumed that both of these items would be purchased from established suppliers and manufacturers and delivered directly to the final installation site. For this reason, the cost of these items has not been included as a factory output cost for the purposes of working capital determination. The specific factory costs considered and the resulting working capital requirements for two cases are shown below. The necessity for two cases is based on the assumption of two price levels in the purchase of ionic membranes for the cell stack assembly.

Return on investment requirements for two cases are shown below:

\section{CASE I}

Equipment/Investment

Working Capital

Total:

$$
\begin{aligned}
& 1,562,500 \\
& \frac{2,516,700}{4,079,200}
\end{aligned}
$$

CASE II

$1,562,500$

$2,740,800$

$4,303,300$

Return on Investment @15\% 611,880 or $\$ 612 /$ unit $\$ 645,495$ or $\$ 646 /$ unit .

Taxes $\$ 612 /$ unit - $\$ 646 /$ unit

These costs for taxes and return on investment have been included in the overall cost estimate set forth in the "Cost Summary." 


\section{REDOX BATTERY SYSTEMS \\ 100-MWH ELECTRICAL UTILITY SYSTEM}

\section{SYSTEM DESCRIPTION}

The 100-MWh (10 MW for 10 hours) Redox Energy Storage System is intended for use in an electric utility power system as a load-leveling device for peak periods. It may be located at a central station power plant site or, more likely, at a more remote location on the system where large peak loads exist. In either event, it is presumed that the location is in the continental United States and that no unusual requirements are imposed because of the location including local codes.

The 100 MWh Redox Energy Storage System assumed for this study consists of 475 cell stacks each with 154 active cells (plus one open circuit cell and one rebalance cell). Each stack consists of three substacks connected in series electrically and in parallel hydraulically. The cell stacks are arranged in 19 rows each containing 25 cell stacks, as shown in Figures $10 \mathrm{~A}$ and 10B. Electrically, the rows are cross connected, forming 25 parallel strings of 19 series-connected stacks.

The 25 stacks which make up each row are connected hydraulically in parallel, and each row constitutes a completely separate hydraulic system. A single hydraulic system consists of the storage tanks, pumps, and plumbing for the two electrolytes employed in one row. Each electrolyte is stored in a single, subgrade storage tank. A submersible pump, mounted from the top of the tank, circulates the electrolyte through the cell stacks and back. The piping just downstream from the pump is divided into three parallel circuits, one for each cell substack. Subsequently, each of the three main circuits further divides into 25 parallel circuits, one for each cell stack in the row. The three return circuits are not manifolded, but enter the tank, at the top, individually. The piping is virtually all above grade. Electrolyte flow is the same whether the system is charging or discharging. The flow through each substack is balanced by hand valves in the cell stack exit piping. This series-parallel arrangement of plumbing and electrical connections minimizes shunt current losses by providing isolating plumbing between cell stacks and by minimizing voltages of individual stacks. 


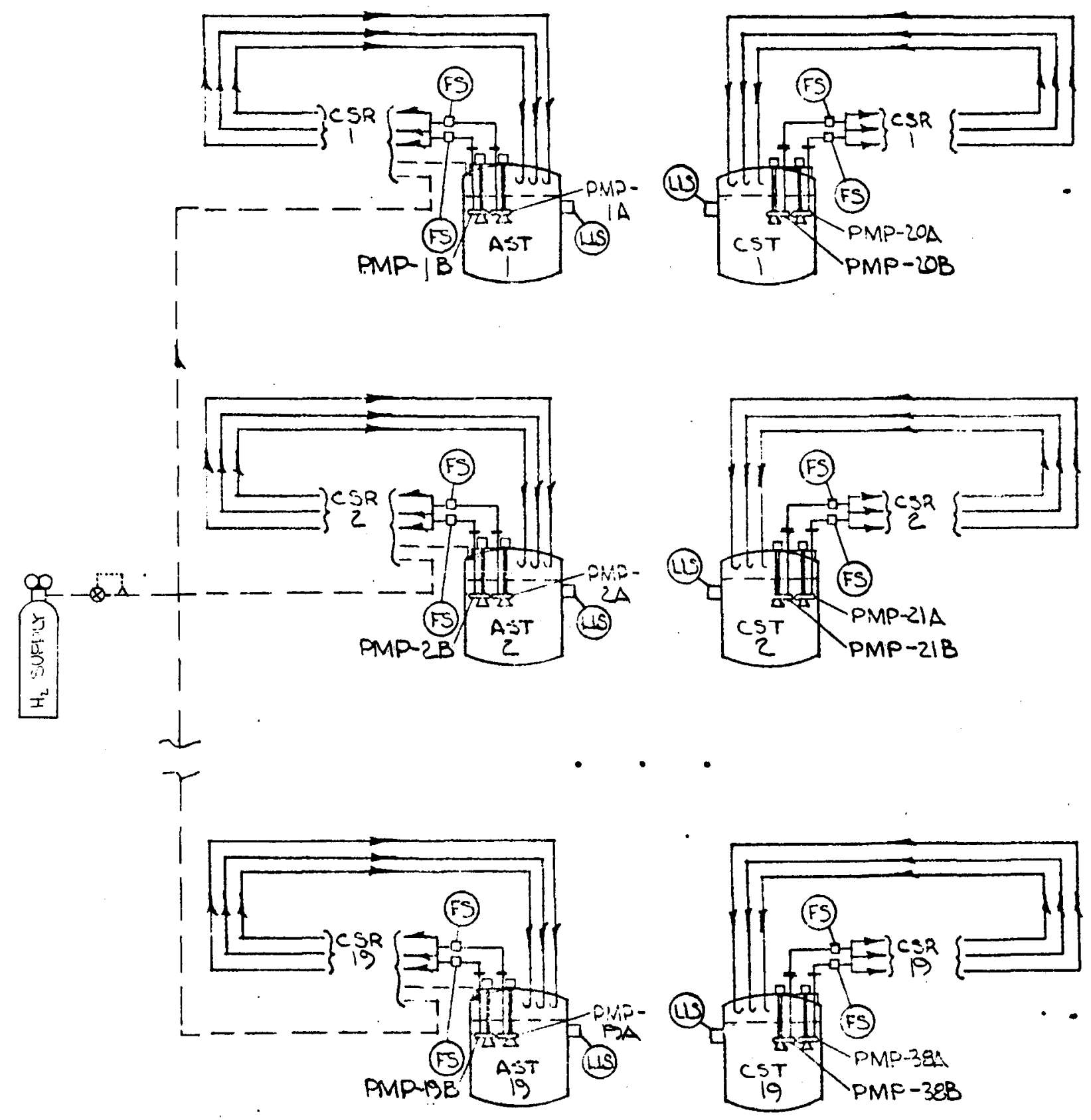

ELECTROLYTE

AST- ANOLYTE STORAGE TANK

CST- CATHOLVTE STORAGE TANK.

CSR-CLLL STACK ROW
- - - HYDRDGEN

CSS-CELL STAKK STRING FVD-PUMP LLS - LONLENL ENITCH

FS - FLOW SNITCH

$54-17$

Figure 10A. Fluid Schematic of $10 \mathrm{~mW} / 100 \mathrm{mWh}$ System 

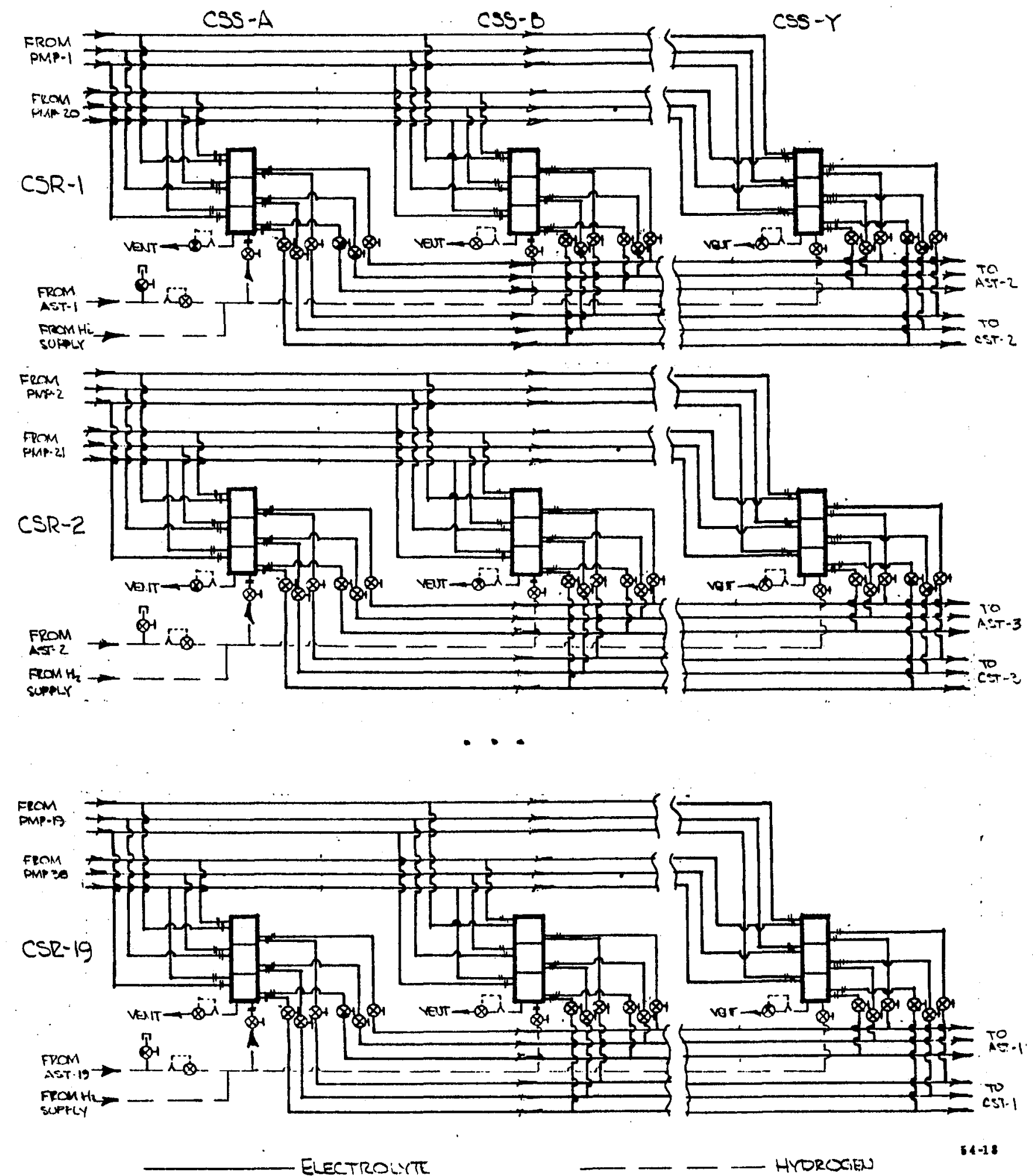

Figure 10B. Fluid Arrangement Around Cell Stack 
During charging, a small amount of hydrogen is evolved from the anolyte and collects in the top of the anolyte storage tank. Eventually, this side reaction would result in a reduction in the usable capacity of the anolyte and, therefore, of the entire system. The hydrogen supply system provides a means of returning the hydrogen to the anolyte by reacting it, electrochemically, with the catholyte in the rebalance cell.

The system is connected to the utility grid, as shown in Figure 11. The pumps and controller operate on utility ac power. The controller is manually energized, but the pumps are energized by the controller. Depending on the voltage across the load, the Redox system is either charged or discharged.

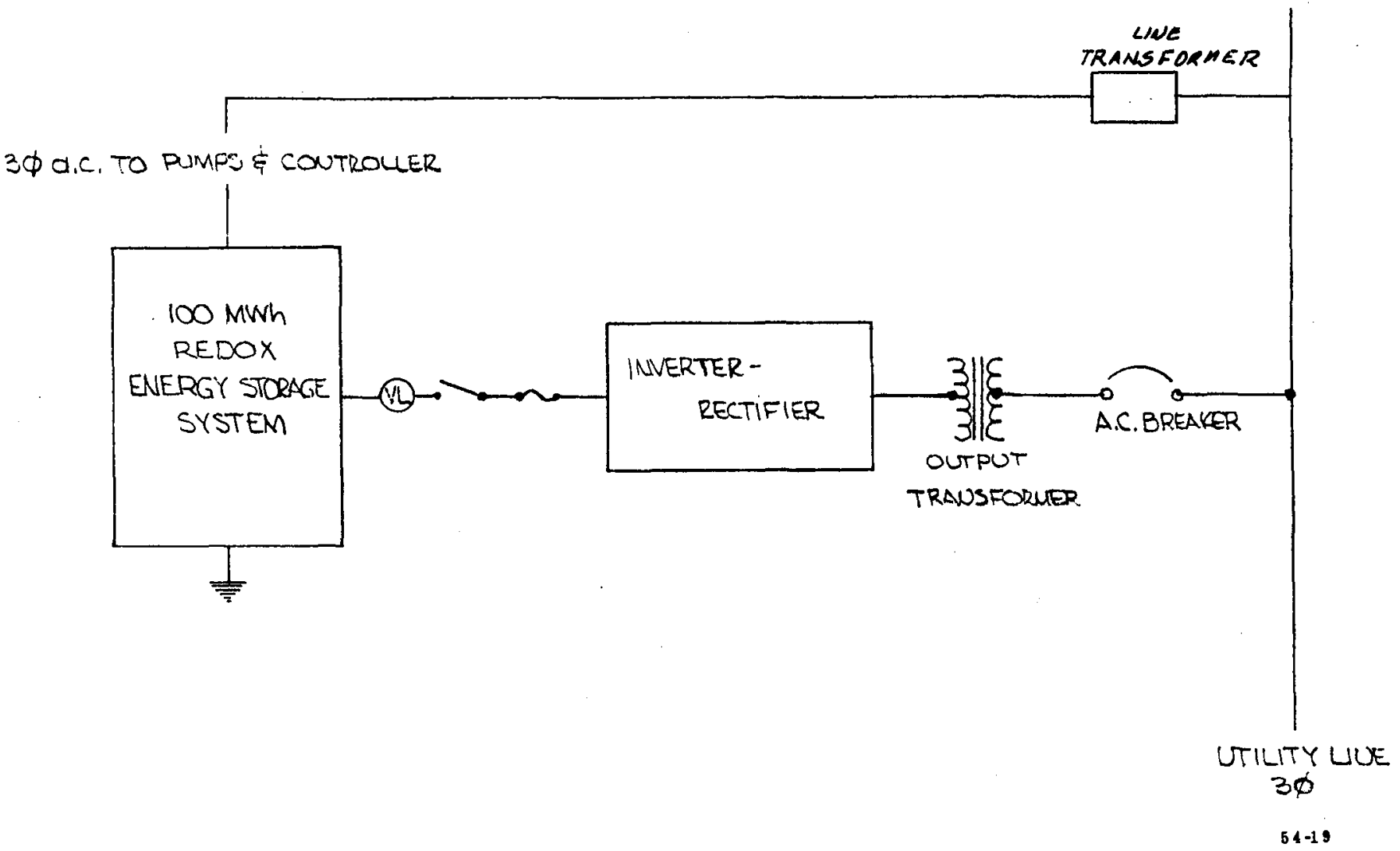

Figure 11. One-Line Electrical Schematic - 10mW/100mWh System 
A conceptual physical arrangement of the $100 \mathrm{MW}-\mathrm{hr}$ Redox Energy Storage System is depicted in Figure 12. The 25 stacks in each row are arranged on five racks; each rack supporting five stacks, one over the other. The racks in each row are placed about 3 feet apart. The 19 rows are arranged in two side by side banks with 10 and 9 rows respectively, and are placed about 8 feet apart. The tanks for alternate rows are buried on either side of each. The total area required for the system is 1.32 acres, about 240 feet by 240 feet. This entire area is enclosed in a building designed to promote natural ventilation. In this way, it is possible to consider a system with no active thermal management system (i.e., without fans, pumps, cooling fluids, etc.).

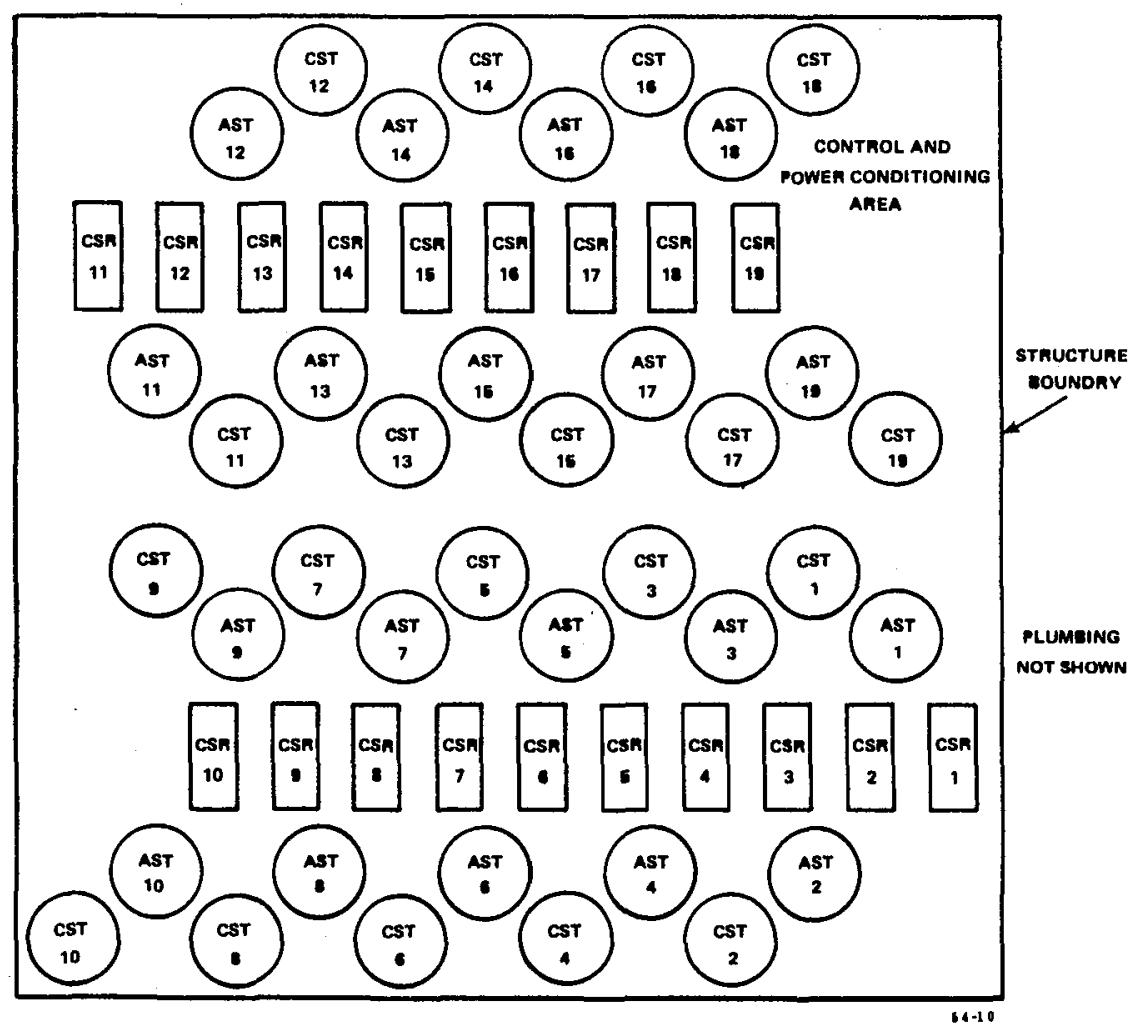

Figure 12. 10mW/100mWh Redox Energy Storage System Plot Plan

System performance and operating parameters are listed in Table IX. The system design has evolved based on a number of assumptions, guidelines and constraints which were developed by NASA and PSD and are listed in Appendix C. 
TABLE IX

SYSTEM PERFORMANCE \& OPERATING PARAMETERS $10 \mathrm{~mW} / 100 \mathrm{mWh}$

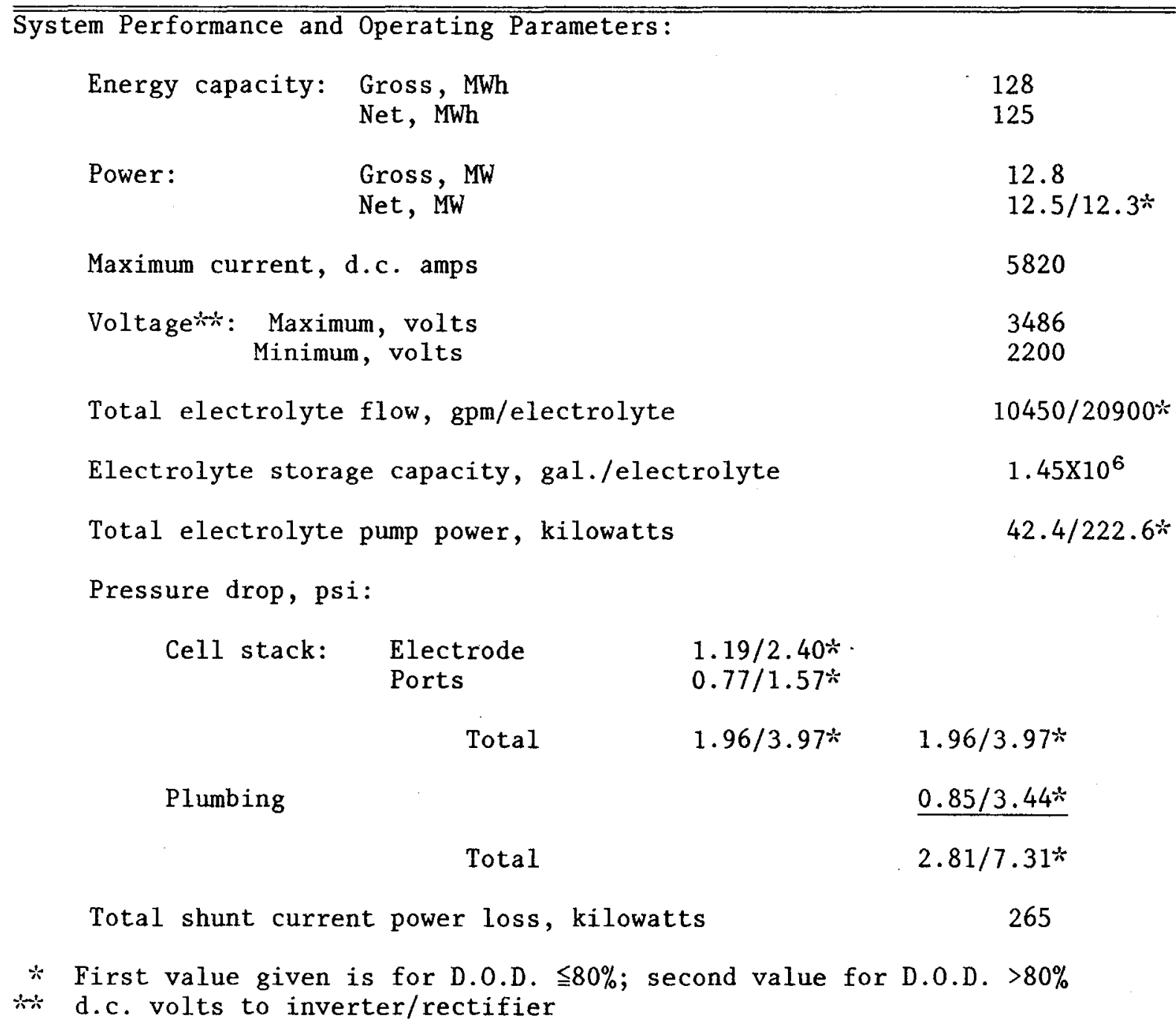

\section{COST SUMMARY}

The cost estimate for the 100-MWH Redox Energy Storage System has been developed following the guidelines for estimating the capital costs of advanced battery systems prepared by A.D. Little for the Electric Power Research Institute. The total manufacturer's selling price for this system ranges from $\$ 63 / \mathrm{kWh}$ to $\$ 110 / \mathrm{kWh}$ depending on the assumption as to the cost of the chromium chloride reactant. 
The elements of the two selling prices are shown in Table $X$. In both cases the major system cost is that of the reactants and tankage which totals 56 to 71 percent of the total cost. Cell stack and balance-of-system costs total 10 to 20 percent of the total cost. Business related costs are relatively small. A cost discussion for each of the major cost elements is contained in the following sections of this report.

TABLE $X$

$10 \mathrm{~mW} / 100 \mathrm{mWh}$ SYSTEM COSTS

ANRUAL PRODUCTION RATE - 100 UNITS

\begin{tabular}{|c|c|c|c|c|c|c|c|}
\hline Cost & Element & Dollars & & $\$ / \mathrm{Ft}^{2}(1)$ & \multicolumn{3}{|c|}{$\$ / \mathrm{kWh}^{(2)}$} \\
\hline \multicolumn{8}{|c|}{ Cell Stack } \\
\hline & $\begin{array}{l}\text { L Labor } \\
\text { o Materials } \\
\text { Sub-Total; Cell Stack }\end{array}$ & $\begin{array}{r}209,223 \\
1,099,340 \\
1,308,563\end{array}$ & & $\begin{array}{r}1.61 \\
8.48 \\
10.09\end{array}$ & , & $\begin{array}{r}1.67 \\
8.80 \\
10.47\end{array}$ & \\
\hline \multicolumn{8}{|c|}{ Balance-of-System } \\
\hline & $\begin{array}{ll}0 & \text { Labor } \\
0 & \text { Materials }\end{array}$ & 98,154 & & 0.76 & & 0.78 & \\
\hline & $\begin{array}{ll}- & \text { Structure } \\
- & \text { Plumbing } \\
- & \text { Control } \\
- & \text { Pumps } \\
\text { - Sub-Total; Balance-of-System }\end{array}$ & $\begin{array}{r}368,000 \\
816,840 \\
66,900 \\
570,000 \\
1,919,000\end{array}$ & & $\begin{array}{l}14.05 \\
14.81\end{array}$ & · & $\begin{array}{l}14.57 \\
15.36\end{array}$ & \\
\hline & $\begin{array}{l}\text { Tanks } \\
\text { Chemicals }\end{array}$ & $1,748,000$ & & 13.48 & & 13.98 & \\
\hline & $\begin{array}{ll}\circ & \mathrm{CrCl}_{3}-6 \mathrm{H}_{2} \mathrm{O} \\
\circ & \mathrm{FeCl}_{3} \\
\circ & \mathrm{HCl}\end{array}$ & $\begin{array}{r}1,728,500 \\
624,750 \\
428,700\end{array}$ & $(7,022,080)$ & 21.45 & $(62.28)$ & 22.26 & $(64.60)$ \\
\hline & Sub-Total; Tanks \& Chemicals & $4,529,950$ & $(9,823,530)$ & 34.93 & $(75.76)$ & 36.24 & $(78.59)$ \\
\hline & $\begin{array}{l}\text { Equipment Depreciation } \\
\text { Rent }\end{array}$ & $\begin{array}{l}12,845 \\
11,880\end{array}$ & & 0.19 & & 0.20 & \\
\hline & Factory Cost Total & $7,783,132$ & $(13,398,072)$ & 60.02 & $(103.32)$ & 62.27 & $(107.18)$ \\
\hline & $\begin{array}{l}\text { Return on Investment } \\
\text { Taxes }\end{array}$ & $\begin{array}{l}165,659 \\
165,659\end{array}$ & $\begin{array}{l}(180,120) \\
(180,120)\end{array}$ & 2.55 & $(2.78)$ & 2.65 & $(2.88)$ \\
\hline & Manufacturer's Selling Price & $8,114,450$ & $(13,758,312)$ & 62.58 & $(106.10)$ & 64.92 & $(110.07)$ \\
\hline (1) & Based on cell area of $129,675 \mathrm{Ft}^{2}$ & & & & & & \\
\hline (2) & Based on energy storage capability & $125 \mathrm{MWh}$ & & & & & \\
\hline
\end{tabular}




\section{ELECTROLYTES AND REACTANTS}

The electrolytes employed in this design were those prescribed by the NASA. Described in the fully charged state, the anolyte is composed of $2 \mathrm{M} \mathrm{CrCl}_{2}$ supported in a $2 \mathrm{~N} \mathrm{HCl}$ aqueous solution, and the catholyte is composed of a $2 \mathrm{M} \mathrm{FeCl}_{3}$ supported in a $2 \mathrm{~N} \mathrm{HCl}$ aqueous solution. In operation, the degree of charge varies between $90 \%$ and $10 \%$. Operating to such a deep state of discharge, although minimizing the quanity of electrolytes required, would impose a severe parasite power penalty were it not for the use of a dual pump arrangement that significantly reduces that penalty when the degree of charge drops below $20 \%$.

Although the essential properties are different for each electrolyte and vary for each from the charged to discharged state, they are similar enough to permit the use of the same value for both electrolytes whether charged or discharged. These property values are listed below:

\section{Property $\quad \underline{\text { Value }}$}

$\begin{array}{lc}\text { Density }\left(1 \mathrm{bm} / \mathrm{ft}^{3}\right) & 80.2 \\ \text { Viscosity }(1 \mathrm{bm} / \mathrm{ft}-\mathrm{sec}) & 1.45 \mathrm{X10}^{-3} \\ \text { Electrical conductance }\left(\mathrm{ohm}^{-1}-\mathrm{in}^{-1}\right) & 1.4554 \\ \left.\text { Specific heat (Btu/1bm- }{ }^{\circ} \mathrm{F}\right) & 0.8 \\ \text { Thermal conductivity }\left(\mathrm{Btu} / \mathrm{hr}-\mathrm{ft}-{ }^{\circ} \mathrm{F}\right) & 0.384\end{array}$

The major portion of the electrolytes is stored in tanks external to the cell stacks. The amount of each electrolyte required, and, hence, the required storage volume, is a function of the gross watt-hour capacity required of the power plant, the depth of discharge range, reduction in capacity due to permanent crossdiffusion of the electrolytic couple (taken as $25 \%$ in this design), and the average full-load voltage (taken as 0.9 volts at $50 \%$ D.0.D.). With these factors taken into account, the required quantity of each electrolytic solution is $1,213,000$. gallons. 
For the chromic chloride electrolyte this translates into a requirement for 5,165,600 pounds as shown in Table XI. NASA has defined two cost levels for this chemical of $\$ 1.30 /$ pound and $\$ 0.32 /$ pound. At these prices the per unit cost of chromic chloride varies from $\$ 1,728,500$ to $\$ 7,022,080$ or $\$ 13.83 / \mathrm{kWh}$ to $\$ 56.18 / \mathrm{kWh}$. Table XI also sets forth the price of the ferric chloride and hydrochloric acid required for each unit. Per pound prices for these chemicals were determined from chemical trade journals. The total price of chemicals for each system varies from $\$ 22.26 / \mathrm{kWh}$ to $\$ 64.61 / \mathrm{kWh}$ depending on the chromic chloride price assumed.

TABLE XI

REDOX BATTERY SYSTEM

$10 \mathrm{~mW} / 100 \mathrm{mWh}$ ELECTRICAL UTILITY UNIT

COST OF CHEMICALS

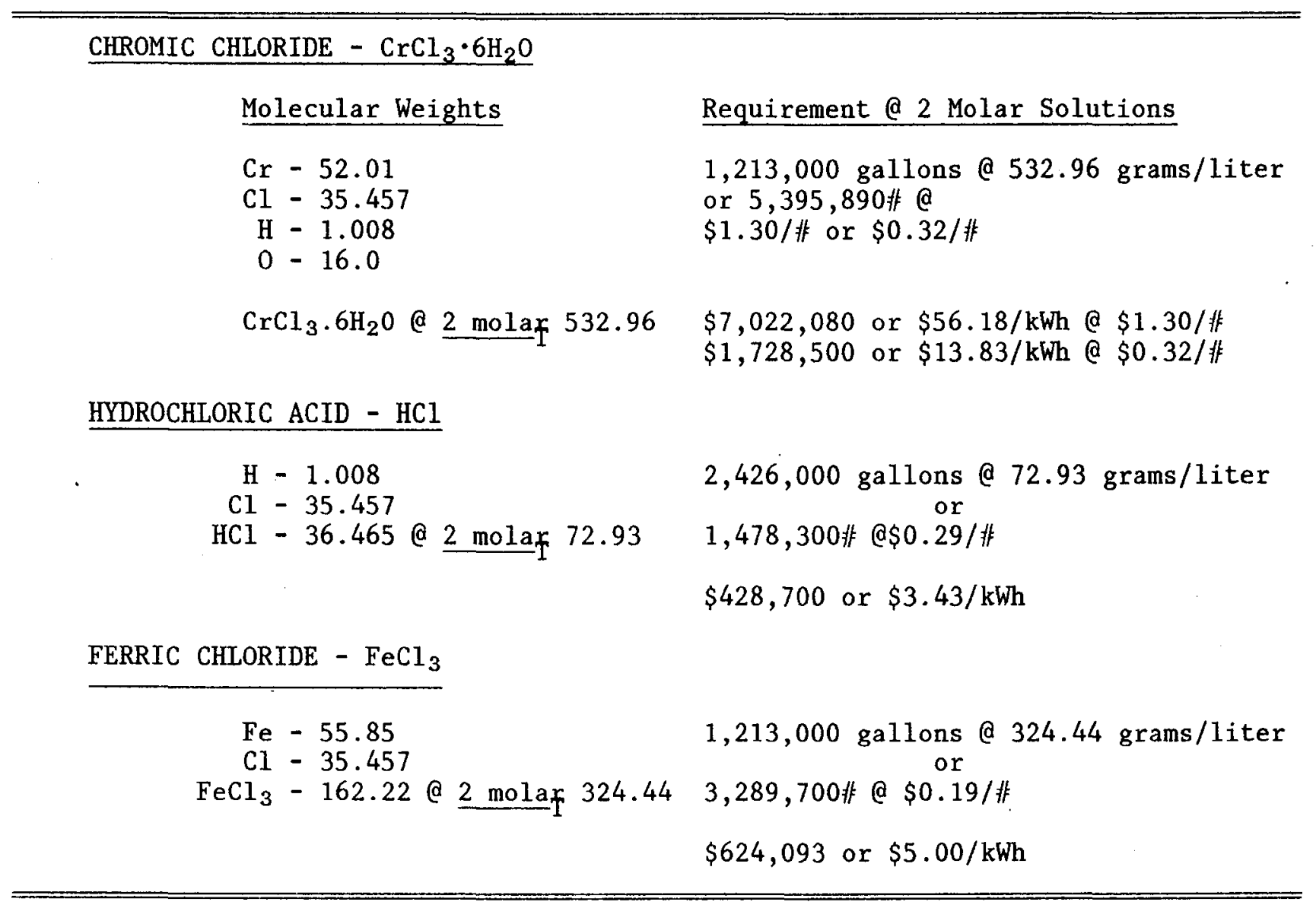


The reactant tankage concept for storage of the required 2,426,000 gallons of solution includes thirty-eight, 76,600 gallon underground fiberglass storage tanks. These tank sizes allow for approximately 20\% ullage. Because of the enormity of the storage tank facility, it was decided to install the tanks below grade (below the frost line) for maximum environmental protection and to ensure that the electrolytic solutions can drain out of the cell stack and plumbing completely when the power plant is shut down. This greatly facilitates maintenance on all components except the tanks themselves, and eliminates the requirement for special supporting structures. The arrangement is as shown in Figure 13.

Selection of the tank material considered such factors as structural integrity, life, compatibility with the electrolytic solutions and cost.

Options considered included plastic-lined steel tanks and fiberglass tanks. Rubber pillow tanks were also investigated, but are obviously limited to above ground use.

Discussions with tank suppliers ${ }^{(1)}$ indicated good structural life and electrolyte compatibility characteristics for both the plastic-lined steel and fiberglass tanks. A concern in the area of life and electrolyte compatibility was noted for the pillow tanks. Cost comparisons for the tank options are shown in Figure 14. The lowest cost option is a pillow tank, followed by the fiberglass tank, with the plastic-lined steel tank the most costly. It should be noted that the possibility of further cost reductions was indicated by all suppliers and could be realized with more specific purchase negotiations considering the quantity of tanks (950 per year) required.

Based on these factors fiberglass tanks were selected for inclusion in this study. Thirty-eight tanks of 76,000 gallons each are required. Consistent with the cost information in Figure 14 a cost of $\$ 0.60$ per gallon was assumed. On this basis each tank cost $\$ 46,000$ and the total tankage cost per system is $\$ 1,748,000$ or $\$ 13.48 / \mathrm{Ft}^{2}$ of cell area and $\$ 13.98 / \mathrm{kWh}$. 


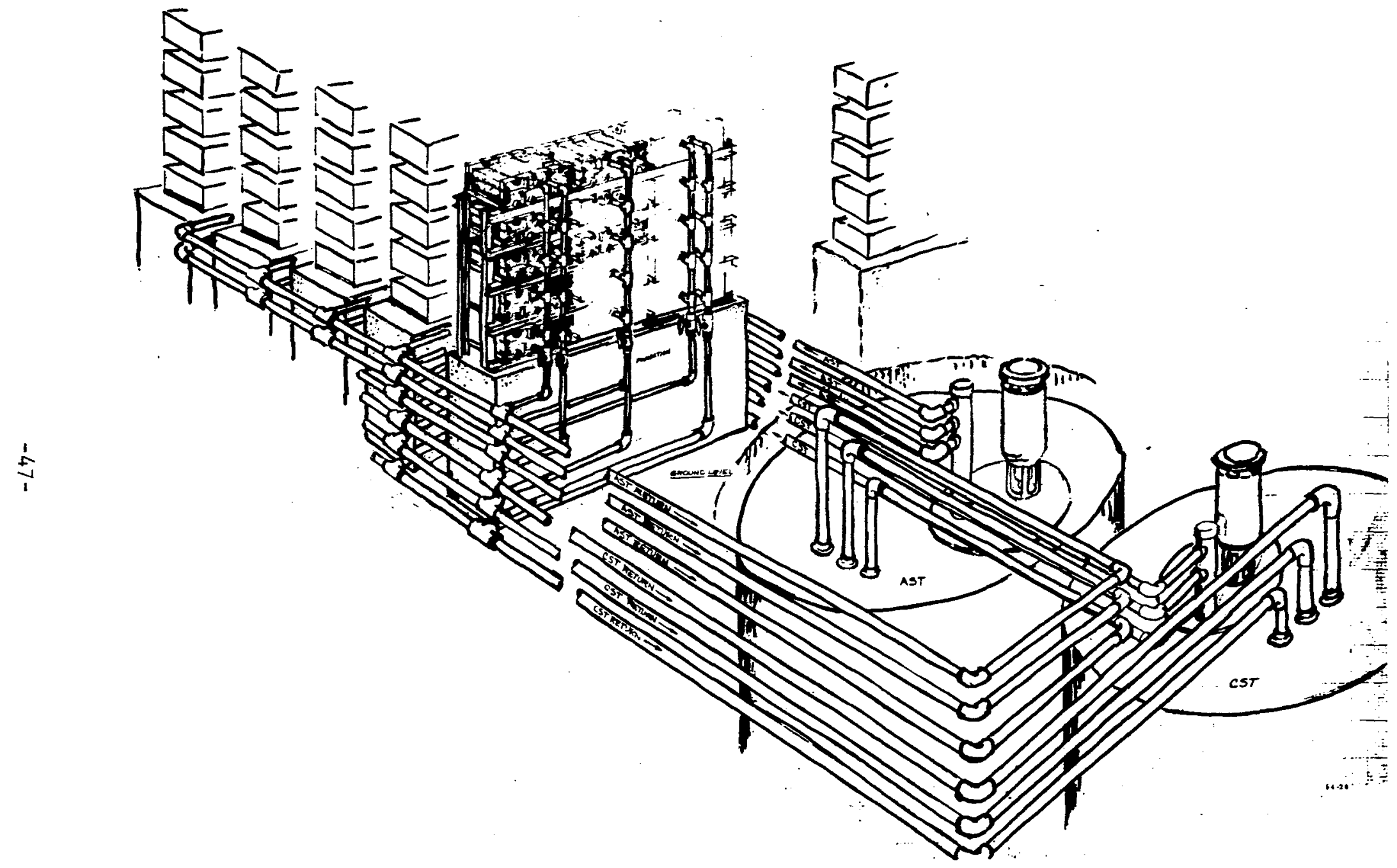

Figure 13. Typical Stack and Plumbing Arrangement 


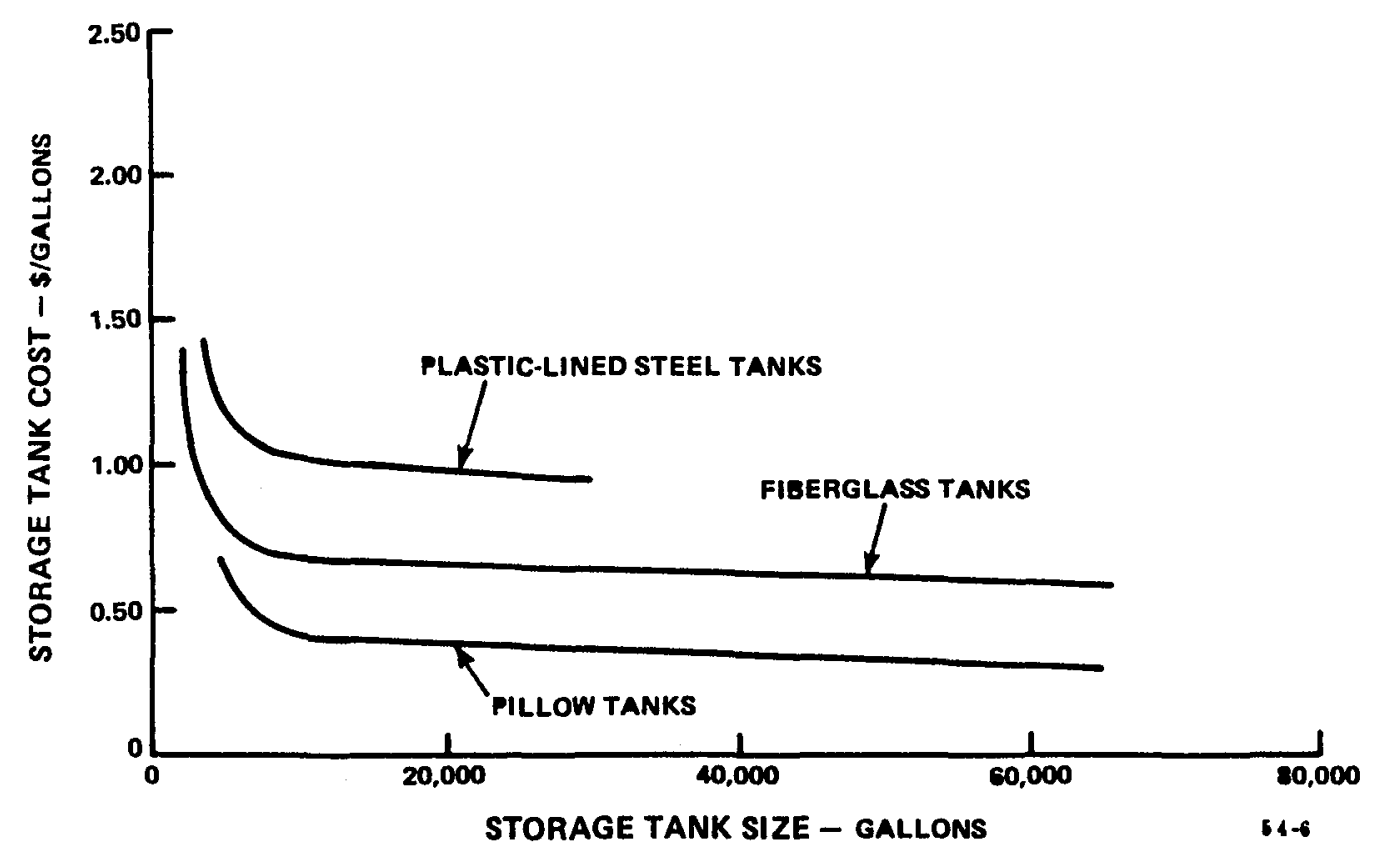

Figure 14. Cost Comparison for Tanks - 10mW/100mWh System

\section{CELL STACK}

\section{Arrangement}

The cell stack in this design consists of 156 cells, electrically in series, divided into three cell substacks of 52 cells each. One rebalance cell and one open circuit cell are included in the total number. All 154 active cells are permanently "on-line" since no trim cells are required. Specifically, Substack 1 contains the rebalance cell, located at the far positive end to simplify the hydrogen plumbing, and 51 permanently connected cells. Substack 2 contains 52 permanently connected cells. Substack 3 contains 51 permanently connected cells, and the open circuit cell at the far negative end. The substacks are mounted side by side and the five cell stacks one over the other on a simple U-channel frame. The frame is about $10.5 \mathrm{ft}$. wide by $10 \mathrm{ft}$. high by $2 \mathrm{ft}$. deep. This arrangement is shown in Figure 13. 
In order to reduce the shunt current loss in the internal electrolyte manifolds of the cell stack, each substack is hydraulically in parallel with the others. Thus, the maximum full load voltage from one end of a manifold to the other is about $1 / 3$ of the total across the stack. Only through the external plumbing is the full cell stack voltage seen, and there, the electrolyte paths, and hence, the electrical resistance between substacks may be made as large as required. The problem of shunt currents due to the voltage differential between the rows of stacks in eliminated by handling the electrolytes for each row in completely separate hydraulic systems.

For purposes of this study, the cell designed for the 500-kWh application was used in the 100-MWH design. Its design is described in Section III pages 14 through 17.

All the cells in the power plant are of the same configuration, including the open circuit cell and the rebalance cell. The rebalance cell is located at one end of the cell stack so that the hydrogen connections can be made easily. For this cell, the end plate, insulator plate and collector plate have two additional openings to supply hydrogen to the anolyte electrode and vent any excess away.

The manufactured cost of this cell stack assembly varies from $\$ 1,308,563(\$ 10.47 /$ $\mathrm{kWh})$ to $\$ 1,619,923(\$ 12.96 / \mathrm{kWh})$ depending upon the assumption for the cost of the ionic membrane. The costs for significant cost elements are listed in Table XII. Material costs reflected in this table are derived from a mixture of sources including NASA guidelines, vendor quotes, vendor discussions, or current prices from material cost journals. Major material cost elements include the cost of the ionic membrane and the electrode felt.

Cell stack assembly labor costs are based on a detailed facility and associated labor assessment discussed in the section "Manufacturing Facility." Labor costs total a relatively small 13 to 16 percent of the total cell stack assembly cost. Many of the stack elements are the product of high volume, automated production processes which tend to mimimize labor costs. 
TABLE XII

CELL STACK ASSEMBLY COST

$10 \mathrm{~mW} / 100 \mathrm{mWh}$ System

\begin{tabular}{|c|c|c|c|c|c|c|c|}
\hline COST ELEMENT & $\begin{array}{l}\text { Piece Re- } \\
\text { quirement }\end{array}$ & $\begin{array}{l}\text { Pieces per } \\
\text { System }\end{array}$ & $\begin{array}{l}\text { System Re- } \\
\text { qui rement }\end{array}$ & $\begin{array}{l}\text { Material } \\
\text { Unit Cost }\end{array}$ & $\begin{array}{l}\text { Material } \\
\text { Cost }\end{array}$ & $\begin{array}{l}\text { Labor } \\
\text { Cost }\end{array}$ & $\begin{array}{l}\text { Total } \\
\text { Cost }\end{array}$ \\
\hline IONIC MEMBRANE & $2.06 \mathrm{ft}^{2}$ & 74,100 & $152,646 \mathrm{ft}^{2}$ & $\begin{array}{l}\# 2 / F t^{2} \\
\$ \frac{o r}{F} t^{2}\end{array}$ & $\begin{array}{l}\$ 305,292 \\
\$ 610,584\end{array}$ & - & $\begin{array}{c}\$ 305,292 \\
\stackrel{\text { or }}{=} \\
\$ 610,584\end{array}$ \\
\hline PLASTIC FRAME & $1.72 \#$ & 148,200 & $254,904 \#$ & $\$ 0.50 / \#$ & $\$ 127,452$ & $\$ 38,745$ & $\$ 166,197$ \\
\hline ELECTRODE FELT & $1.85 \mathrm{ft}^{2}$ & 148,200 & 274,170 & $\$ 1.61 / \mathrm{Ft}^{2}$ & $\$ 441,414$ & & \\
\hline $\begin{array}{l}\text { ELECTRODE CATALYS } \\
\text { GOLD } \\
\text { LEAD }\end{array}$ & $\begin{array}{r}30 \mu \mathrm{g} / \mathrm{cm}^{2} \\
200 \mu \mathrm{g} / \mathrm{cm}^{2}\end{array}$ & -- & $\begin{array}{l}116.4 \text { T.oz. } \\
53.2 \text {. }\end{array}$ & $\begin{array}{l}\$ 300 / T .0 z . \\
\$ 0.25 / \text { 非 }\end{array}$ & $\begin{array}{l}\$ 34,920 \\
\$ 1,330\end{array}$ & $\$ 23,247$ & $\$ 500,911$ \\
\hline $\begin{array}{l}\text { BI-POLAR SEP- } \\
\text { ARATOR PLATES }\end{array}$ & $1.35 \#$ & 74,100 & 100,035 非 & $\$ 0.475 /$ \#\# & $\$ 47,517$ & $\$ 74,907$ & $\$ 122,424$ \\
\hline PLASTIC GASKET & 0.27 \# & 148,200 & 40,014 非 & $\$ 0.50 /$ 非 & $\$ 20,007$ & & \\
\hline $\begin{array}{l}\text { PLASTIC "O" } \\
\text { RINGS }\end{array}$ & $31.6 \#$ & 950 & 30,020 非 & $\$ 0.85 / \#$ & $\$ 25,517$ & $\$ 14,637$ & $\$ 124,945$ \\
\hline INSULATOR PLATES & 3.3\# & 2,850 & $9,405 \#$ & $\$ 0.50 / \#$ & $\$ 4,703$ & & \\
\hline END PLATES & 27.1 非 & 2,850 & 77,235 非 & $\$ 0.55 /$ \# & $\$ 42,479$ & & \\
\hline TIE RODS & 1.12 非 & 17,100 & $19,152 \#$ & $\$ 0.30 / \#$ & $\$ 5,746$ & & \\
\hline ASSEMBLY OF STACK & & & . & & & $\$ 57,687$ & $\$ 57,687$ \\
\hline TOTAL & & & & & $\begin{array}{l}\$ 1,056,377 \\
\$ 1,3 \frac{\text { or }}{61}, 669\end{array}$ & $\$ 209,223$ & $\begin{array}{l}\$ 1,277,456 \\
\$ 1,5 \overline{\text { or }} \\
\$ 1,748\end{array}$ \\
\hline $\begin{array}{l}\text { TOTAL WITH 95\% } \\
\text { MATERIAL YIELD }\end{array}$ & & & & & $\begin{array}{l}\$ 1,111,975 \\
\$ 1, \frac{\text { or }}{33}, 336\end{array}$ & $\$ 209,223$ & $\begin{array}{l}\$ 1,344,690 \\
\text { or } \\
\$ 1,640,935\end{array}$ \\
\hline
\end{tabular}

A discussion of labor cost is contained in Section "Manufacturing Facility"

SYSTEMS STRUCTURE AND PLUMBING

The 100-MWH system structure, as considered in this study, is the framework associated with mounting of the cell stacks and a building which houses the entire Redox Energy Storage System. 
The cell stack mounting framework is a simple U-channel steel frame. Each frame provides mounting space for 15 -cell substacks and is approximately $10.5 \mathrm{ft}$. wide by $10 \mathrm{ft}$. high by $2 \mathrm{ft}$. deep. Although each frame is rather simple, the large number of cell stacks result in a structural steel requirement of 92,300 pounds for each 100-MWH system. A structural steel price of $\$ 0.21 /$ 非 has been assumed based on trade journal information. Assuming a $95 \%$ yield in the production process and applying a $10 \%$ material overhead results in a total structural steel cost of $\$ 22,400$ or $\$ 0.18 / \mathrm{kWh}$. Labor cost for structure assembly is discussed in the section "Manufacturing Facility."

The entire 100-MWH Redox Energy Storage System is housed in a building that is 240 feet by 240 feet $\left(57,600 \mathrm{Ft}^{2}\right)$ with a minimum inside height of 15 feet. Built into the sides, ends, and roof are openings fitted with adjustable closures that can be used to promote natural ventilation across the exposed electrolyte piping and cell stacks.

The building serves two purposes: one is to protect the cell stacks and other equipment from the elements, and the second is to provide a passive thermal management system utilizing the adjustable openings in the walls and roof. The use of passive cooling appears feasible based on an estimate of the waste heat generated by the system, the heat dissipation capability of the electrolyte piping, and the cell stacks themselves. Needless to say, the use of the active thermal management system would add significantly to the cost and the already high parasite power.

The cost of this building has been estimated on a one-of-a-kind basis for each specific installation in accordance with a standard cost estimating procedure. The cost totals $\$ 345,600$ or $\$ 2.76 / \mathrm{kWh}$ and includes the foundation/slab, basic metal structure, doors for ventilation and subcontract labor for site erection.

The electrolyte plumbing delivers the electrolytes from the storage tank to the cell stacks in the row and back again. The plumbing must be a dielectric, chemically inert when exposed to the electrolyte and sized to provide a minimum pressure drop with shunt current losses. It must also provide uniform flow to each of the 
three cell substacks that comprise the cell stack and each of the cell stacks in the row.

Polyvinyl/chloride (PVC), readily available from a number of sources in pipe and a wide variety of fittings and valves, was selected as the plumbing material. It is in general use by the chemical industry for handling corrosive, acidic materials, and it has shown itself to be unaffected in such service. Furthermore, it is thermally stable in the temperature range anticipated in this design.

The problem of power loss due to shunt currents in the external piping between cell substacks was handled by separating both the supply and return lines to each cell substack as close to the storage tanks as possible to maximize the electrical resistance, but the pipe size did not result from minimizing the combined pump power/shunt current power loss. Rather, the lines were sized to maintain nearly the same mass velocity throughout. And that mass velocity was set by the substack flow rate and the previously fixed cell stack manifold inlet diameter.

Trim valves are provided in the electrolyte return lines at the cell stack exit to permit balancing the flow to each cell substack and cell stack after installation. While small flow variation may be tolerated by the system, any significant variation would have a marked effect on performance. Pipe couplings are provided in the supply line at the pump exit and at the cell substacks. These couplings permit removal of the cell stack or the pumps without major plumbing involvement.

PVC components for the reactant supply system were selected from vendor catalogs (5) and are listed in Table XIII. Unit prices reflect current vendor catalog prices with appropriate discount for quantities required in the production of 100 systems per year: Total reactant supply system cost is $\$ 749,200$ or $\$ 5.99 / \mathrm{kWh}$.

Hydrogen is supplied to the rebalance cells in each cell stack from the anolyte storage tank or, if required, from a single on-site auxilliary hydrogen supply. Hydrogen plumbing is composed of flexible polyvinyl tubing, PVC valves and standard brass gas pressure regulators. 
TABLE XIII

PLUMBING/VALVE SCHEDULE

$10 \mathrm{~mW} / 100 \mathrm{mWh}$ System

\begin{tabular}{cccc}
\hline \multirow{2}{*}{ Cost Element } & Quantity & Unit & Cost per \\
& Per System & Price & System
\end{tabular}

Reactant Supply System

- PVC Schedule 40 piping

- 3 inch diameter

- 6 inch diameter

- 8 inch diameter

- PCV Socket Tees

- 3 inch diameter

- 6 inch diameter

- PVC Socket Elbows

- 3 inch diameter

- 6 inch diameter

- PVC Socket Reducers

- $\quad 2$ inch $\leftrightarrow 1 \frac{1}{2}$ inch

- 3 inch $\leftrightarrow 2$ inch

- 6 inch $\leftrightarrow 3$ inch

- PVC Socket Coupling

- 6 inch

- PVC Single Entry Ball Valve

- PVC Solvent

Total; Reactant Supply System

Total with $95 \%$ yield and $10 \%$ overhead

\begin{tabular}{|c|c|c|}
\hline $\begin{array}{r}23,000 \mathrm{f} \\
22,500 \mathrm{f} \\
150 \mathrm{f}\end{array}$ & $\begin{array}{l}\$ 1.50 / \mathrm{ft} \\
\$ 3.87 / \mathrm{ft} \\
\$ 5.98 / \mathrm{ft}\end{array}$ & $\begin{array}{lr}\$ & 34,500 \\
\$ & 87,075 \\
\$ & 900\end{array}$ \\
\hline $\begin{array}{r}4,560 \\
912\end{array}$ & $\begin{array}{l}\$ 6.00 \\
\$ 34.00\end{array}$ & $\begin{array}{l}\$ 27,360 \\
\$ 31,000\end{array}$ \\
\hline $\begin{array}{r}2,280 \\
874\end{array}$ & $\begin{array}{l}\$ 4.70 \\
\$ 24.00\end{array}$ & $\begin{array}{ll}\$ & 10,700 \\
\$ & 20,975\end{array}$ \\
\hline $\begin{array}{l}5,700 \\
5,700 \\
1,140\end{array}$ & $\begin{array}{l}\$ 8.00 \\
\$ 29.00 \\
\$ 40.00\end{array}$ & $\begin{array}{l}\$ 45,600 \\
\$ 165,300 \\
\$ 45,600\end{array}$ \\
\hline $\begin{array}{r}1,140 \\
1,140 \\
235 \\
\text { gallons }\end{array}$ & $\begin{array}{l}\$ 11.00 \\
\$ 140.00 \\
\$ 25 / \\
\text { gallon }\end{array}$ & $\begin{array}{l}\$ 12,540 \\
\$ 159,600 \\
\$ 5,875\end{array}$ \\
\hline
\end{tabular}

$\$ 647,025$

$\$ 749,200$

A gas pressure regulator acts to release hydrogen from the anolyte storage tank to the rebalance cell based on storage tank $\mathrm{H}_{2}$ pressure. The upper $\mathrm{H}_{2}$ pressure in the rebalance cell is controlled by vent pressure regulators on each cell stack and the low $\mathrm{H}_{2}$ pressure is controlled by the pressure regulator in the auxilliary $\mathrm{H}_{2}$ supply. In this way, the rebalance cells are assured of enough hydrogen without the danger of overpressuring the cells. 
Hydrogen supply system components listed in Table XIV were also selected and priced in accordance with current vendor catalogs. Total hydrogen supply system cost is $\$ 67,640$ or $\$ 0.54 / \mathrm{kWh}$.

TABLE XIV

HYDROGEN SUPPLY SYSTEM

$10 \mathrm{~mW} / 100 \mathrm{mWh}$ : System

\begin{tabular}{|c|c|c|c|}
\hline Cost Element & $\begin{array}{l}\text { Quantity } \\
\text { Per System }\end{array}$ & $\begin{array}{l}\text { Unit } \\
\text { Price }\end{array}$ & $\begin{array}{c}\text { Cost per } \\
\text { System }\end{array}$ \\
\hline $\begin{array}{l}\text { Hydrogen Supply System } \\
\text { Flexible tube; } \frac{1}{2} \text { inch } \\
\text { Check valve } \\
\text { Vent valve } \\
\text { Vent valve } \\
\text { Tees/nipples } \\
\text { Pressure gages }\end{array}$ & $\begin{array}{l}3,400 \mathrm{ft} . \\
475 \\
475 \\
475 \\
- \\
495\end{array}$ & $\begin{array}{c}\$ 0.75 / \mathrm{Ft} \\
\$ 29.00 \\
\$ 10.00 \\
\$ 30.00 \\
-- \\
\$ 27.00\end{array}$ & $\begin{array}{l}, 550 \\
\$ 13,775 \\
\$ 4,750 \\
\$ 14,250 \\
\$ 9,725 \\
\$ 13,365\end{array}$ \\
\hline Total - Hydrogen supply system & & & $\$ 58,415$ \\
\hline Total with $95 \%$ yield and $10 \%$ overhead & & & $\$ 67,640$ \\
\hline
\end{tabular}

CONTROLS

The control requirements for a Redox Energy System operating in a public utility system may vary significantly depending on the utility and its location. A large utility operating a complicated power network may routinely use highly sophisticated data processing equipment and, therefore, desire highly detailed performance data and control function input. On the other hand, a relatively small utility may impose only the basic control requirements. In either case, a central station location might allow virtually constant operator attention, with less reliance on the contoller, while a remote location might dictate fully automatic operation with remote start/stop control and data reporting.

Any of these options, or others that might come to mind, would have important consequences relative to the complexity of the controller and to its cost. Since 
these factors are not clearly definable at this time, a cost of $\$ 50,000$ or $\$ 0.40 /$ kWh for this controller is used in this study and is based on past experiences representative of a medium complexity controller.

For this study, only the most basic control functions have been assumed with the following operating modes:

$\begin{array}{ll}\text { o } & \text { Start } \\ 0 & \text { Run-Discharge } \\ 0 & \text { Run-Charge } \\ 0 & \text { Shutdown } \\ 0 & \text { Emergency Shutdown }\end{array}$

These modes are described more fully in Appendix D.

The power plant is designed for automatic operation once started. The start function, however, is manual and requires an external electrical supply (i.e., it will not "boot-strap" start). Control of the power plant is vested in a programmable controller. This type of controller was chosen because of its relative simplicity coupled with the capacity to perform the control functions and accept the required input and output signals. It is capable of receiving contact closures and 20 voltage signals from the instrumentation provided for power plant monitoring and control, and generating appropriate control signals as required to implement the various power plant control functions.

The input signals provided by the instrumentation incorporated in the power plant are as follows:

- Low electrolyte level switches on each storage tank (38)

- Flow switches in each electrolyte flow loop (76)

- Open circuit cell voltmeter (19)

- Line (load) voltage voltmeter (1)

o Start/stop switch (1) 
Electrical components. All electrical cable and bus bars are copper, with appropriate insulation, sized to carry the required current with a $50^{\circ} \mathrm{C}$ temperature rise or less.

The cabling arrangement is simple. The cell substacks in each stack and all cell stacks in each string are connected in series with insulated 3/0 cable carrying 233 amps. Connections to the load tabs are made with clevis-type clamps. Each group of five strings, which results by virtue of the way the stacks are mounted in the racks, is connected together at their far positive and far negative end by bus bars that are 6 inch by 0.5 inch. These bus bars carry 1164 amps and are connected at each end to a larger bus bar consisting of three parallel 4 inch by 0.5 inch bars separated by "stand-offs". The large bus bars carry the full load of 5820 amps. All bus bars are insulated. Electrical component costs total $\$ 11,900$ as indicated in Table XV.

TABLE XV

ELECTRICAL CONNECTORS/CABLES

$10 \mathrm{~mW} / 100 \mathrm{mWh}$ System

\begin{tabular}{|c|c|c|c|}
\hline Cost Element & $\begin{array}{l}\text { Quantity } \\
\text { Per System }\end{array}$ & $\begin{array}{l}\text { Unit } \\
\text { Price }\end{array}$ & $\begin{array}{l}\text { Cost per } \\
\text { System }\end{array}$ \\
\hline \multicolumn{4}{|l|}{ Electrical Connectors/Cables } \\
\hline $\begin{array}{ll}\text { O } & \text { Connector lugs; } 2 \text { hole crimp } \\
\text { o } & \text { Copper cable } 3 / 0 \\
0 & \text { Copper bus bars } \\
& \text { Insulation - shrink tube }\end{array}$ & $\begin{array}{l}1,000 \\
2,750 \mathrm{ft} \\
\quad 470 \text { 非 } \\
\quad 385 \mathrm{ft}\end{array}$ & $\begin{array}{l}\$ 2.49 \\
\$ 2.35 / \mathrm{ft} \\
\$ 2.05 / \text { 非 } \\
\$ 0.95 / \mathrm{Ft}^{2}\end{array}$ & $\begin{array}{l}\$ 2,490 \\
\$ 6,460 \\
\$ \quad 965 \\
\$ \quad 365\end{array}$ \\
\hline \multicolumn{2}{|l|}{ Total electrical connectors/cables } & \multicolumn{2}{|r|}{$\$ 10,280$} \\
\hline \multicolumn{2}{|l|}{ Total with $95 \%$ yield and $10 \%$ overhead } & & $\$ 11,900$ \\
\hline
\end{tabular}

PUMPS

Each electrolyte flow loop contains two pumps in parallel. One pump handles 550 gpm with a pressure rise of $2.81 \mathrm{psi}$ when operating above at depths-of-discharge 
less than $80 \%$. When the depth-of-discharge exceeds $80 \%$, the second pump is energized. Both pumps, operating together, handle $1100 \mathrm{gpm}$ with a pressure rise of 7.3 psi. All parts of the pumps exposed to the electrolyte must be constructed of materials non-corrosive in the electrolyte or coated with such materials. Furthermore, the pumps must be self-priming or located in such a manner as to preclude the need for priming.

Submersible, centrifugal pumps in the capacity-head range mentioned above and not requiring priming by virtue of their submersibility, are available in polyvinyl chloride (PVC) or other suitable materials at reasonable cost.

Discussions with pump manufacturer ${ }^{(7)}$ indicate the cost of a pump of this type would be approximately $\$ 7,500$ in the quantities required (950 per year). With seventy-six pumps required for each system, pump costs total $\$ 570,000$ or $\$ 4.56 / \mathrm{kWh}$.

The efficiency of such pump-motor combinations in this size range are typically $55 \%$ to $60 \%$ representing the best available short of employing a special design that would greatly add to the cost. For this study, a combined pump-motor efficiency of $60 \%$ was used which led to a total pump power requirement of $223 \mathrm{~kW}$ when the depthof-discharge is greater than $80 \%$ and $42 \mathrm{~kW}$ when the depth-of-discharge is less than $80 \%$.

Each pump is mounted from a mounting plate located on the top side of the buried tank with the motor extending above the plate into an equipment pit and the pump housing the impeller extending down into the tank below the lowest electrolyte level normally encountered. Access to the pump-motor assembly is gained from the equipment pit through a grade-level man-hole. The whole assembly can be withdrawn from the tank for easy maintenance.

The pump mounting plate must be designed in such a way as to permit a gas-tight seal to be maintained between the tank and pump assembly in order to prevent the escape of hydrogen from the anolyte storage tank. Furthermore, it will be necessary to take special precautions to prevent an explosive mixture of hydrogen from 
existing in the equipment pit over the anolyte storage tank at all times, but particularly during maintenance activities.

MANUFACTURING FACILITY

A manufacturing facility layout has been developed for the 100-MWH system based on the assumption of an annual production rate of 100 units and the make/buy split shown in Table XVI. The facility envisioned is a 237,600 $\mathrm{Ft}^{2}$ building which is shown in Figure 15. The facility includes major areas for the manufacture of cell stack and structural components, assembly of cell stacks, storage of raw materials and purchased parts, shipping of finished components, and supporting office and service areas.

The facility would operate on a three-shift basis and employ 891 personnel directly in manufacturing and assembly operations and 180 personnel in quality control and other support functions for a total of 1,071 direct employees. The basic hourly labor rate utilized in this study is $\$ 5.74$ per hour which has been derived from U.S. Department of Labor statistics for the Greenville, Tennessee area and represents a mix of labor skill levels including skilled, semi-skilled, and unskilled. Total labor cost per $100-$ MWH unit is $\$ 307,377$ or $\$ 2.80 / \mathrm{kWh}$ as shown in Table XVII.

TABLE XVI

MAKE/BUY SPLIT

\begin{tabular}{llll}
\hline \multicolumn{1}{c}{ MAKE } & BUY \\
\hline Cell Stack Components (except ionic membrane) & o & Ionic Membrane \\
$\circ \quad$ Structure/Plumbing & o & $\begin{array}{l}\text { Electronic/Electrical } \\
\text { Components }\end{array}$ \\
$0 \quad$ Power Plant Assembly & o & Pumps \\
& o $\begin{array}{l}\text { Electrolyte Storage } \\
\text { Tanks }\end{array}$ & & Electrolytes
\end{tabular}




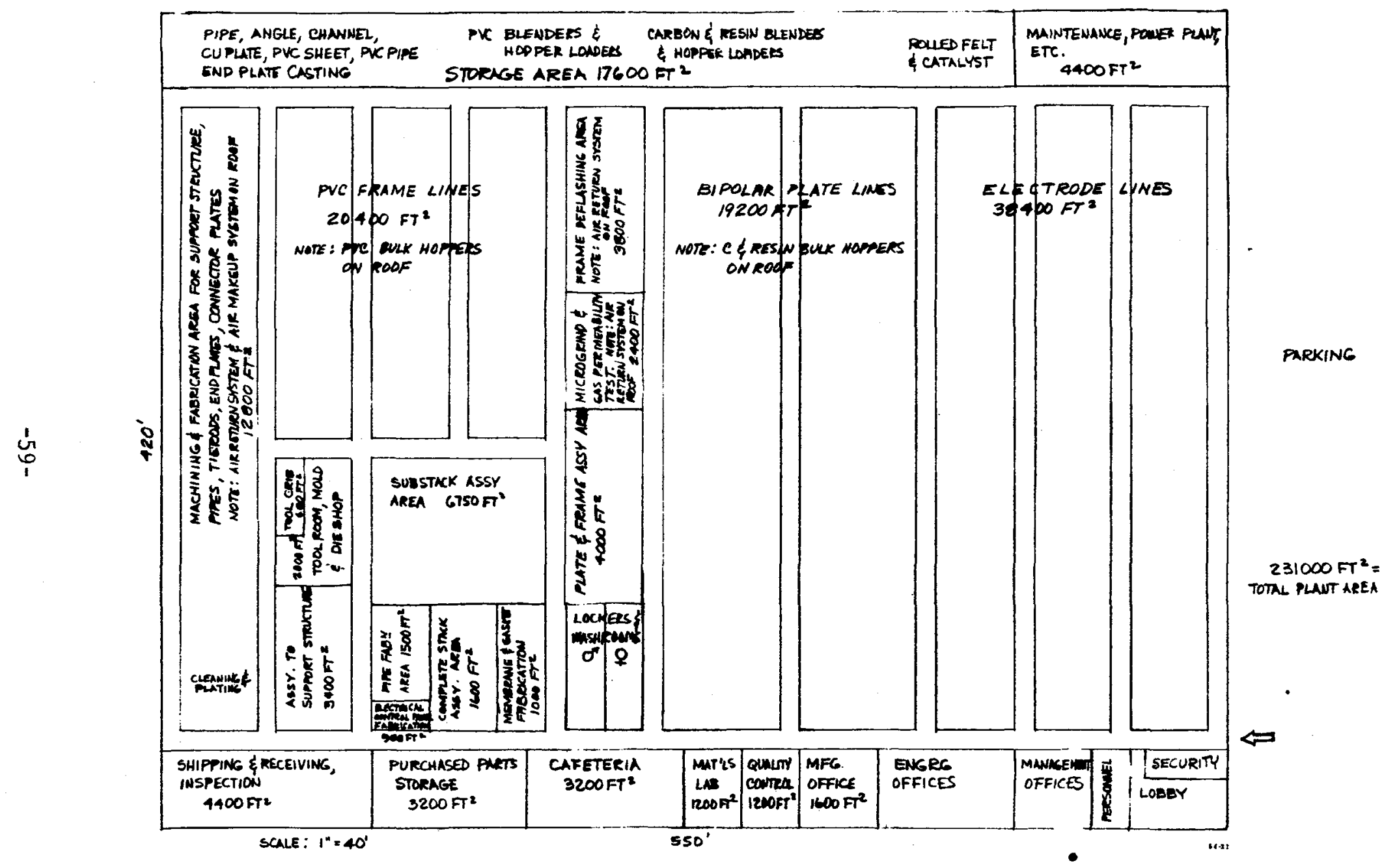

Figure 15. Drawing of Facility Building - 10mW/100mWh System 
TABLE XVII

REDOX BATTERY SYSTEM. LABOR COSTS - 10 MV EIECTRIC UTILITY UNIT.

19 MODULES - 25 STACKS/MOD - 156 CELLS/STACK $-1.75 \mathrm{Ft}^{2} /$ CELL $-129,675 \mathrm{Ft}^{2} ; 10 \mathrm{~m} / 100 \mathrm{wh}$

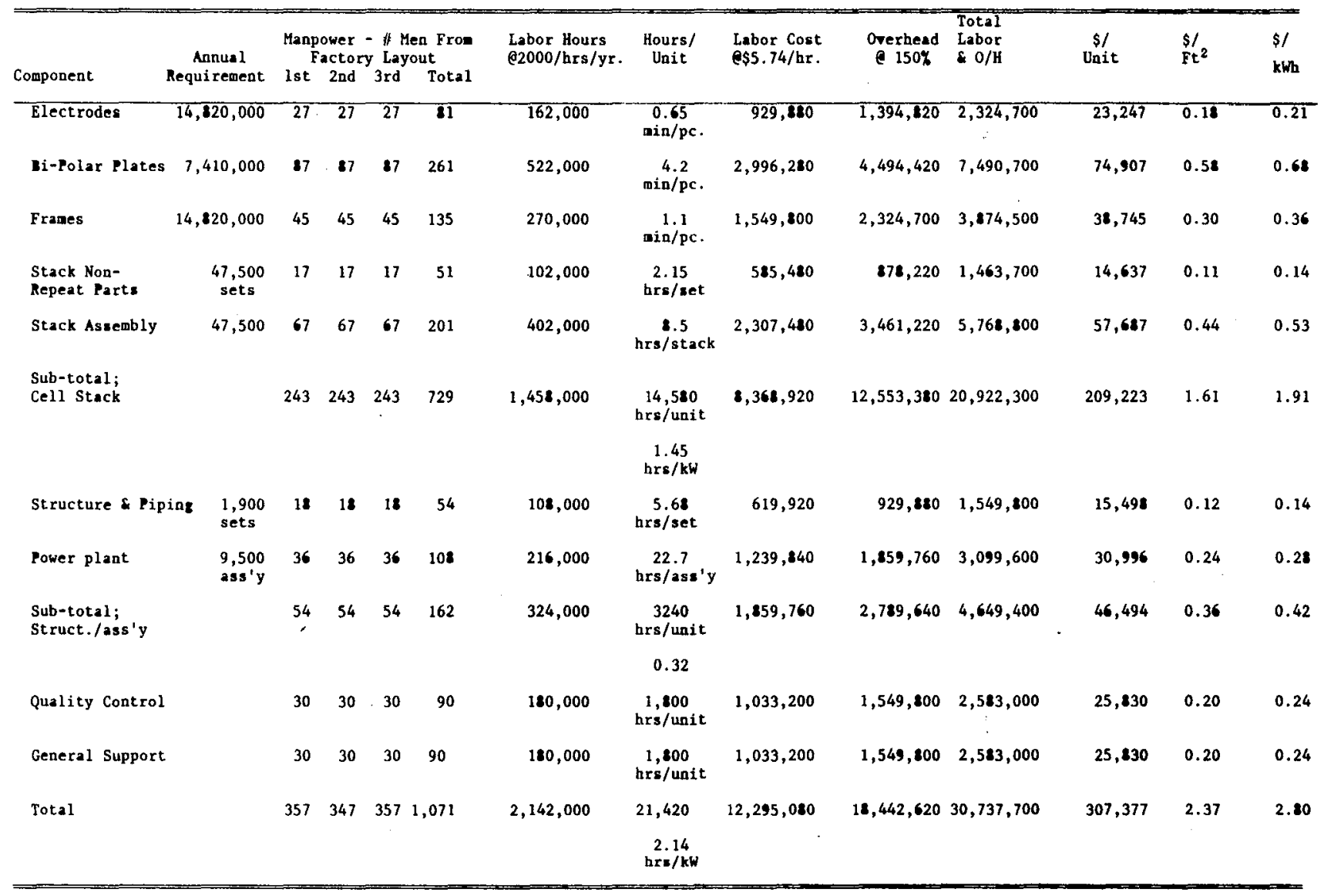

An assessment of production equipment requirements for this plant indicates an equipment investment requirement of $\$ 10,275,150$, equipment installation costs at 25 percent or $\$ 2,568,800$, yielding a total equipment investment of $\$ 12,843,950$.

Consistent with the basic cost study guidelines which include a facility space rental charge of $\$ 5$ per square foot and a ten year straight-line depreciation approach for capital equipment, the resulting costs per 100-MWH unit for these cost items are $\$ 11,880 /$ unit for facility space and $\$ 12,845 /$ unit for equipment depreciation.

The manufacture of cell stack components reflected in Figure 15 include the making of cell related parts including electrodes, bi-polar plates, plastic forms and 
stack related parts including end plates, tie rods, collector plates and insulators.

Electrode manufacture assumes the purchase of the basic carbon felt in large rolls. The carbon felt strip is then drawn continuously through an immersion tank for catalyst application and through a continuous $300^{\circ} \mathrm{F}$ oven for a 30 -minute electrode heat treatment. The continuous electrode strip is then cut to proper size and stored for later use in the cell stack assembly. Overall electrode production rate is two pieces per minute per production line. Annual production rate per shift for the 27 lines shown in Figure 15 is $\$ 6,480,000$ pieces, Total annual electrode requirement for 100 units is $14,820,000$ and requires three-shift operation in this area. Electrode production is anticipated to be a very automatic operation with one man required for operation. At this level of staffing electrode production labor cost becomes $\$ 0.18 / \mathrm{ft}^{2}$ or $\$ 0.21 / \mathrm{kWh}$ as shown in Table XVII.

Bi-polar plate production involves several manufacturing operations including mixing of the graphite power and phenolic resin, extruding, calendaring and cutting the blank plates, hot pressing the blank plates, heat treating operations, microgrinding to finish dimensions, and a gas permeability test. A total of 7,410,000 bi-polar plates are required on an annual basis. A total of 87 men per shift for three shifts, are involved in the manufacture of these plates resulting in a labor cost of $\$ 0.68 / \mathrm{Ft}^{2}$ or $\$ 0.68 / \mathrm{kWh}$ as listed in Appendix $\mathrm{E}$.

Manufacture of the plastic frames is accomplished in large injection molding presses at a rate of 2 frames per minute. In addition to the presses, belt sanders are provided for removal of minor plastic flashing following the molding process. 45 men per shift on a 3 -shift basis are required to produce the required $14,820,000$ frames. The resulting labor cost is $\$ .30 / \mathrm{Ft}^{2}$ or $\$ 0.36 / \mathrm{kWh}$.

Stack-related parts including end plates, tie rods, collector plates, and insulators are manufactured by 17 men on a 3-shift basis utilizing a variety of machine tools. The labor costs associated with these parts total $\$ 0.11 / \mathrm{Ft}^{2}$ or $\$ 0.14 / \mathrm{kWh}$. 
Assembly of the cell stacks is carried out in three separate operations beginning with the bonding of the ionic membrane and the two plastic frames. Following this step, electrodes, bi-polar plates, and plastic frames are laid up into 56 cell stacks. In the final assembly step the stack related parts are added to the 56 cell stacks. The stacks are then ready for installation on the power plant structure. Stack assembly is a 3-shift operation utilizing a total of 67 men per shift. Stack assembly labor costs total $\$ 0.44 / \mathrm{Ft}^{2}$ or $\$ 0.53 / \mathrm{kWh}$.

Manufacture of the power plant components reflects the cutting of structural members and welding of portions of the basic frame, cutting all PVC piping to size for later assembly at the installation site, and preparation of electrical controls and wiring for site assembly. The fine cell stack assemblies are completed for shipping to the site. All final power plant assembly beyond that point is assumed to take place at the installation site. Manufacturing plant labor associated with these operations totals 54 men per shift for three shifts and results in a labor cost of $\$ 0.36 / \mathrm{Ft}^{2}$ or $\$ 0.42 / \mathrm{kWh}$.

A significant level of quality control and general support personnel are required for the assumed manufacturing operations. Thirty quality control personnel and thirty general support personnel have been included for each shift of operation.

Manufacturing personnel in the plant total 357 people on each of three shifts for a total of 1,071 production personnel. Total labor costs are $\$ 2.37 / \mathrm{Ft}^{2}$ of cell stack area or $\$ 2.80$ per $\mathrm{kWh}$.

The capital equipment required for this manufacturing operation is summarized in Appendix E. Its anticipated cost totals $\$ 10,275,250$. This cost information is based on a number of contacts with industrial equipment suppliers. In order to arrive at a total equipment investment, an installation cost of 25 percent, or $\$ 2,568,800$, has been added to the basic cost yielding a total investment of $\$ 12,843,950$. 
FINANCIAL CONSIDERATIONS

Financial considerations to be discussed in this section include the areas of return on investment and taxes. Taxes are a straightforward matter since the cost study guidelines define taxes as being equal to return on investment. The discussion then centers on return on investment.

Return on investment is defined by the cost study guidelines as 15 percent of the manufacturing equipment investment plus necessary working capital. The equipment requirements and associated investment for the 100 units per year were discussed in the section Manufacturing Facility. Total equipment investment was determined to be $\$ 12,843,950$ or $\$ 128,440 /$ unit.

Working capital is further defined by the cost study guidelines as 30 percent of the annual factory output costs noted below:

- Labor
o Materials and Purchased Components
- Overhead
- Equipment Depreciation
- Rent

These costs are straightforward for this sytem with the exception of the classification of the costs for reactants and tankage. It has been assumed that both of these items would be purchased from established suppliers/manufacturers and delivered directly to the final installation site. For this reason, the cost of these items has not been included as a factory output cost for the purposes of working capital determination. The specific factory costs considered and the resulting working capital requirements are shown below. This information further indicates the required equipment investment and the return on investement and tax requirements for each of two cases. The necessity for two cases is based on the assumption of two price levels in the purchase of ioninc membranes for the cell stack assembly. 


$$
\frac{\text { CASE I }}{\text { (Optimistic) }}
$$

Factory cost

Working capital @ $30 \%$ of factory cost

Equipment investment

Total; work. cap./equip. inv.

Return on investment a $15 \%$

Taxes

$$
\$ 3,253,182
$$

975,955

128,440

$1,104,395$

165,659

165,659
CASE II

(Conserative)

$$
\$ 3,547,542
$$

$1,072,363$

128,440

$1,200,803$

180,120

180,120

These costs for taxes and return on investment have been included in the overall cost estimate set forth in the section "Cost Summary". 


\section{RESULTS AND CONCLUSIONS}

The studies conducted in this program have defined baseline system designs and estimated system costs for two reference energy storage applications, a 500-kWh stand-alone system for use with an intermittent power source such as a solar photovoltaic array and a larger 100-MWH system for electric utility load leveling. The Redox cell stack design and costing received major emphasis, as this is the contractors primary area of expertise applicable to the Redox system.

Results show the Redox cell stack to be amiable to mass production techniques, with a relatively low material cost. Specific cost is estimated to be $\$ 12.50$ to $\$ 13.00 /$ $\mathrm{ft}^{2}$ which translated to $\$ 5.60 / \mathrm{kWh}$ for the $500-\mathrm{kWh}$ application and $\$ 13.04 \mathrm{kWh}$ for the shorter discharge time 100-MWH mission. In both cases the cell stack cost is a minor factor in total estimated system cost.

In both applcations, system cost is dominated by the cost of the reactants, electrolyte, and associated tankage. In the smaller system with its nominal 50-hour discharge rate, 81 to $87 \%$ of the cost is in these elements. In the larger system with a 10-hour discharge time the percentage is lower, but still a very significant 58 to $73 \%$ of the total cost. The two major elements of this cost are the chromiumchloride anode reactant and the large fiberglass tanks necessary to store the electrolytes.

Total estimated manufacturers selling price for the 500-KWH system varies from $\$ 74$ to $\$ 116 / \mathrm{kWh}$, depending on the assumptions as to the cost of the chromic chloride reactant ( $\$ 0.32$ to $\$ 1.30$ per pound). The higher cost corresponds to present day chromium purity methods; the lower cost is based on a more direct and less costly technique proposed by NASA.

The corresponding selling prices for the electric utility 100-MWH design are $\$ 63$ to $\$ 110 / \mathrm{kWh}$. The lower price level reflects the higher cell performance assumptions for the cell stack and the lower tankage costs associated with 2 molar solutions rather than that of the 1 molar defined for the smaller system. 
These system costs, although higher than original NASA estimates, are believed to be competitive with the battery system such as lead-acid and nickel zinc that offer similar near-term deployment potential. 
VI. REFERENCES

1) TANK SUPPLIERS

- Owens-Corning

Rep: Malcolm Black Associates

5 Deer Park Road

Weatogue, Connecticut

- American Steel \& Iron Works

4247 Fox Street

Denver, Colorado

- Abtrex Industries

Inkster, Michigan

- Goodyear

Engineered Fabrics Division

Rockmart, Georgia

- Kabe-0-Rap Storage Tank

Cooperhill, Tennessee

2) CHEMICAL SUPPLIER

- Borden Thermoplastics Division

Leominster, Massachusetts

3) MATERIAL SUPPLIER

- Fiber Materials, Inc.

Biddeford, Maine 
4) GRAPHITE AND RESIN)

- Asbury Graphite Mills

Asbury, New Jersey

- Reichold Chemicals

White Plains, New York

5) PVC COMPONENTS

- Celanese Piping Systems

Louisville, Kentucky

6) STANDARD COST ESTIMATING PROCEDURE

- Richardson Process Plant Construction Estimating Standards

Solana Beach, California

7) PUMP MANUFACTURERS

- Ingersol1-Rand

Rep: Blare Equipment Company

Bloomfield, Connecticut 
APPENDIX A

500-kWh REDOX ENERGY STORAGE DESIGN PARAMETER 

APPENDIX A

500-kWh REDOX ENERGY STORAGE SYSTEM DESIGN PARAMETERS

\section{Performance}

Net energy storage capacility, kWh 500

Net power capability, $\mathrm{kW}$

Power density, watts/Ft ${ }^{2}$ 50

Output voltage, volts 120

Output voltage voltage regulation, volts $\pm 5$

Output current

d.c.

Discharge time, hrs.

50

Charge time, hrs.

Variable

Charging source Photovoltaic

Depth of Discharge range, $\%$ 10-90

Cell performance

Electrolyte flow

Figure A-1

$1.5 \times 3$ Stoichiometric

\section{Materials}

\section{Cell Stack}

Membranes

Electrodes

Catalysts: Anode

Cathode

Bi-polar (separator) plates
Anion exchange membran supplied by Ionics, Inc. Carbon felt

$$
\begin{gathered}
30^{\mathrm{mgm}} / \mathrm{cm}^{2} \mathrm{AU} \\
200^{\mathrm{mgm}} / \mathrm{cm}^{2} \mathrm{~Pb} \\
\text { None }
\end{gathered}
$$


Power Systems Division

FCR-1784

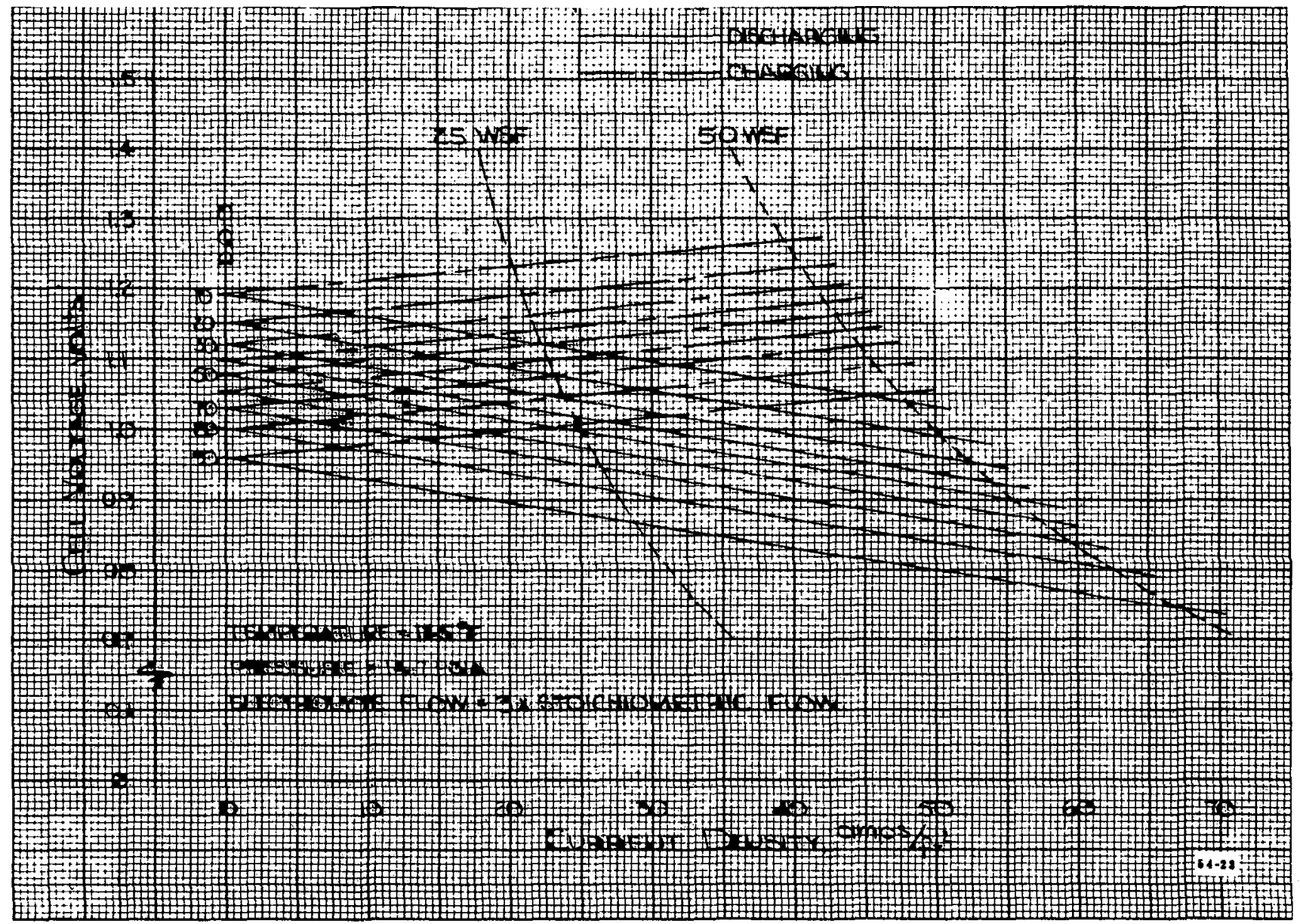

Figure A-1. 500-kWh System Cell Performance 
APPENDIX A (Continued)

500-kWh REDOX ENERGY STORAGE SYSTEM DESIGN PARAMETERS

Frames

Gaskets

Miscellaneous, structural
Compatibility with electrolytes, low cost, life \& maintenance

\title{
Electrolytes
}

\author{
Composition: Catholyte \\ $1 \mathrm{M} \mathrm{FeCl}_{2} / \mathrm{FeCl}_{3}$ \\ Anolyte \\ $1 \mathrm{M} \mathrm{C} \mathrm{Cl}_{3} / \mathrm{C}_{\mathrm{r}} \mathrm{Cl}_{2}$ \\ Support \\ Properties: Density, $1 \mathrm{bm} / \mathrm{ft}^{3}$ \\ $2 \mathrm{~N} \mathrm{HCl}$ aqueous \\ Viscosity, $1 \mathrm{bm} / \mathrm{ft}-\mathrm{sec}$ \\ 71.9 \\ Electrical conductance, \\ ohm $^{-1}$-in ${ }^{-1}$ \\ Specific heat, $\mathrm{Btu} / 1 \mathrm{bm}-{ }^{\circ} \mathrm{F}$ \\ 1.4554 \\ Thermal conductivity, \\ $\mathrm{Btu} / \mathrm{hr}-\mathrm{ft}-{ }^{\circ} \mathrm{F}$ \\ 0.8 \\ $9.06 \times \mathrm{ID}^{-4}$ \\ Components, Piling \& Structure \\ Compatible with electrolytes \\ low cost, life \& maintenance
}

\section{$\underline{\text { Installation }}$}

- The installation will be completely independent of any other on-site facility.

- The erection of a protective enclosure for selected component may be considered.

- The burial of selected components may be considered. 
APPENDIX A (Continued)

500-kWh REDOX ENERGY STORAGE SYSTEM DESIGN PARAMETERS

\section{Environment}

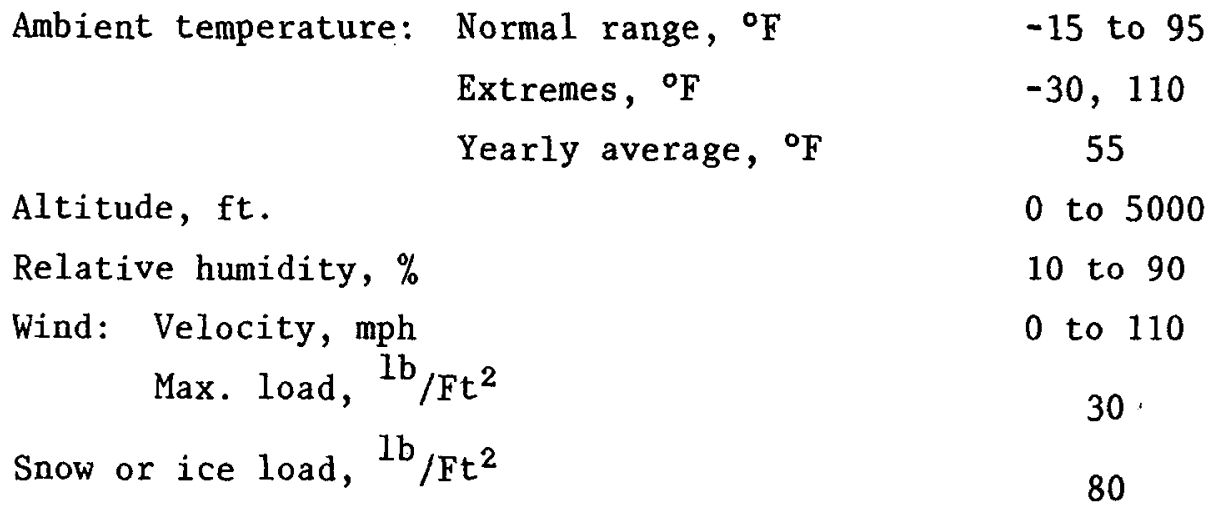

\section{Control}

The power plant shall be designed for automatic, unattended operation.

Operating modes

Supervisory controller

Primary system condition indicator

Voltage regulation

$$
\begin{gathered}
\text { Start } \\
\text { Run - Discharge } \\
\text { Run - Charge }
\end{gathered}
$$

Shutdown

Emergency Shutdown
Open circuit cell voltage

Trim cells 
APPENDIX B

500-kWh CONTROLLER FUNCTION AND ACTIONS 



\section{APPENDIX B}

500-kWh CONTROLLER FUNCTIONS \& ACTIONS

The controller is capable of receiving six contact closure inputs and two voltage inputs from the instrumentation provided for power plant monitoring and control, and generating appropriate control signals as required to implement the various power plant control functions.

The input signals provided by the instrumentation incorporated in the power plant are as follows (see Figures $2 \& 3$ ):

- Low electrolyte level switches on each storage tank (4)

- Flow switches in each electrolyte flow loop (2)

o Open circuit cell voltmeter (1)

- Line (load) voltage voltmeter (1)

With this input, the controller will perform the following functions (instrument notations used below are consistent with that used in the figures referenced above - NC refers to the number of cells in series):

\section{FUNCTIONS}

\section{Start}

(Start is initiated by engaging start switch - assumes controller has been manually energized)

\section{CONTROLLER ACTION}

1. Verify electrolyte storage low level switches (ILS).

a. If level is low (pumps have lost prime), energize warning signal.

b. If level is $\mathrm{OK}$, continue.

2. Start all pumps and energize START light.

3. Verify electrolyte flow with flow switches (FS).

a. If no flow, shutdown, de-energize START light and energize warning signal. 
FUNCTIONS

\section{CONTROLLER ACTION}

b. If flow is indicated, continue.

4. Verify open circuit voltage (VOC).

a. If out of (TBD) range, shutdown de-energize START light and energize warning signal.

b. If open circuit voltage is within TBD range, continue.

c. If the VOC is greater than 1.00 volt, terminate high flow (dual pump) operation and continue with low flow (single pump) operation. 


\section{APPENDIX B}

500-kWh CONTROLLER FUNCTIONS \& ACTIONS

$\underline{\text { Run-Discharge }}$

$\underline{\text { Run-Charge }}$
1. If the previous mode of operation was START, and open circuit voltage VOC is in excess of TBD volts, connect power plant to bus, deenergize START light and energize RUN-DISCHARGE light. During discharge line voltage (VL) is to be maintained between 115 and 125 volts by connecting or disconnecting one or more of five banks of trim cells until the VOC reaches 0.96 volts.

2. If previous mode of operation was RUN-CHARGE and VOC is 1.19 volts, de-energize RUN-CHARGE light. During discharge, line voltage (VI) is to be maintained between 115 and 125 volts by connecting or disconnecting one or more of five banks of trim cells until the open VOC reaches 0.96 volts.

3. Whenever the, $V O C$ is greater than or equal to 1.00 volt, low flow (single-pump) operation should prevail. Whenever the open circuit voltage VOC is less than 1.00 volts, high flow (dual pump) operation should prevail.

1. If previous mode of operation was START, and open circuit voltage (VOC) is less than TBD volts, connect power plant to bus, de-energize START light and energize RUN-CHARGE light. During charge the volts per cell (VL divided by $\mathrm{NC}$ ) is to be maintained in excess of the VOC by connecting or disconnecting one or more of five banks of trim cells until the VOC reached 1.19 volts.

2. If previous mode of operation was RUN-DISCHARGE and open circuit voltage (VOC) is 0.96 volts, de-energize RUNCHARGE light. During charge, the volts per cell (VL divided by NC) is to be maintained in excess of the VOC by 


\section{APPENDIX B}

500-kWh CONTROLLER FUNCTIONS \& ACTIONS

(Continued)

Normal Shutdown

(Shutdown is indicated by engaging SHUTDOWN switch)

Emergency Shutdown connecting or disconnecting one or more of the five banks of trim cells until the VOC reaches 1.19 volts.

3. Whenever the open circuit voltage (VOC) is greater than or equal to 1.00 volt, low flow (single-pump) operation should prevail. Whenever the VOC is less than 1.00 volt, high flow (dual pump) operation should prevail.

1. Disconnect power plant from line.

2. Stop pumps.

3. De-energize run mode light.

4. Controller may be manually shutdown if a complete shutdown is desired.

1. An emergency shutdown will be initiated if any of the following occur:

a. Low electrolyte level signal

b. open circuit voltage out of range

c. flow switch indicates no electrolyte flow 
APPENDIX C

100 MWH ENERGY STORAGE SYSTEM DESIGN PARAMETERS 

APPENDIX C

100-MWH REDOX ENERGY STORAGE SYSTEM DESIGN PARAMETERS

\section{Performance}

Net energy storage capability, MWh

100

Net power capability, MW

Power density, watts $/ \mathrm{Ft}^{2}$

100

Output voltage, volts

13,800

Output voltage regulation, $\%$

$+5$

Output current

a.c.

Discharge time, hrs.

10

Charge time, hrs.

10

Charging source

Depth of Discharge range, $\%$

Utility power system

10-90

Cel1 performance

Electrolyte flow

Figure $\mathrm{C}-1$

$1.5 \times$ Stoichiometric

\section{Materials}

\section{Ce11 Stack}

$\begin{array}{lc}\text { Membranes . } & \begin{array}{l}\text { Anion exchange membrane supplied } \\ \text { by Ionics, Inc. } \\ \text { Electrodes }\end{array} \\ \text { Catalysts: Anode } & 30 \mathrm{mgm} / \mathrm{cm}^{2} \mathrm{AU} \\ & 200 \mathrm{mgm} / \mathrm{cm}^{2} \mathrm{~Pb} \\ \text { Cathode } & \text { None } \\ \text { Bi-polar (separator) plates } & \end{array}$




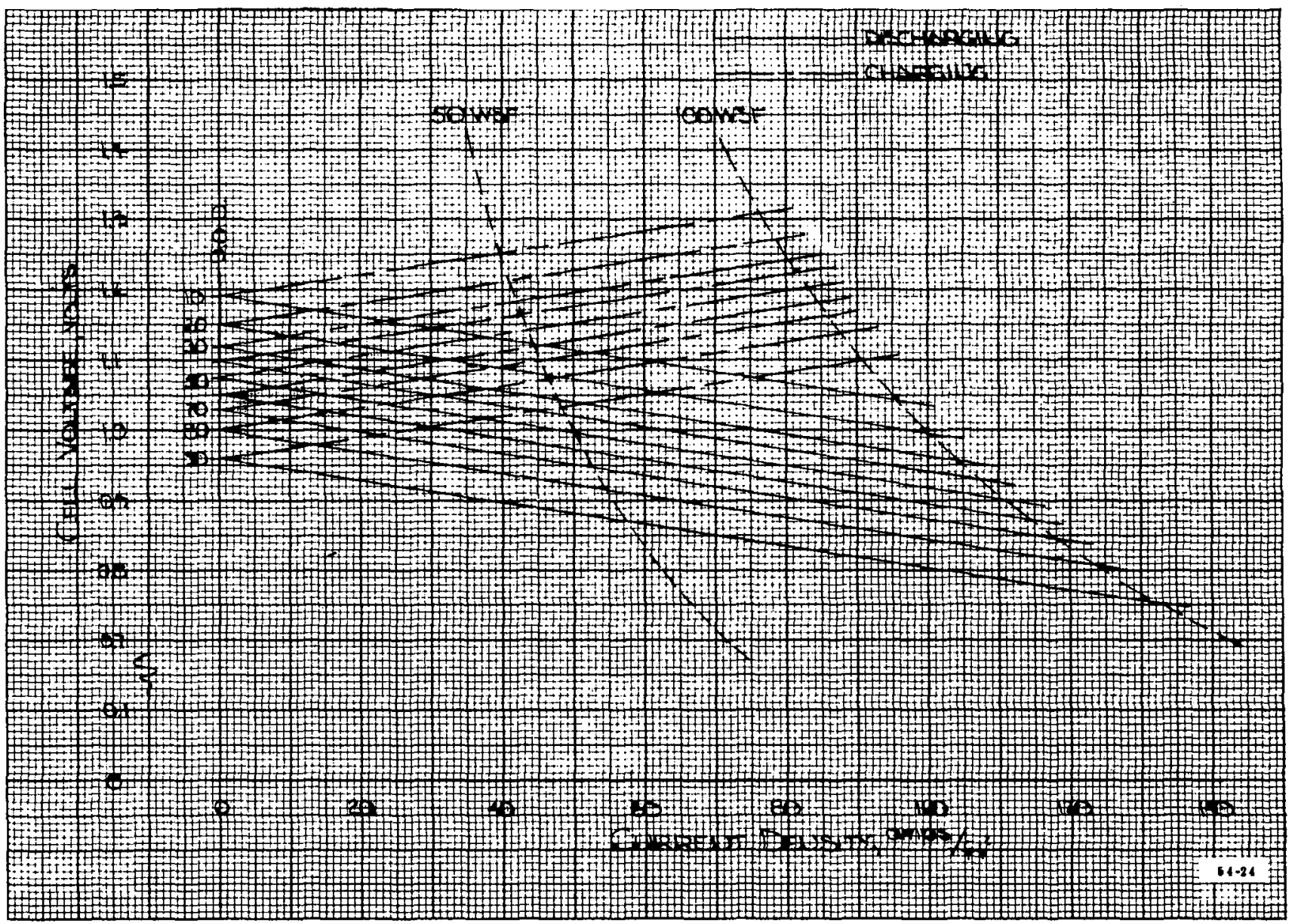

Figure C-1. 100-MWH System Cell Performance 


\section{APPENDIX C (Continued)}

100-MWH REDOX ENERGY STORAGE SYSTEM DESIGN PARAMETERS

Frames

Gaskets

Miscellaneous, structural
Compatibility with electrolytes, low cost, life \& maintenance

\section{$\underline{\text { Electrolytes }}$}

$$
\begin{aligned}
& \text { Composition: Catholyte 2 } \mathrm{M} \mathrm{FeCl}_{2} / \mathrm{FeCl}_{3} \\
& \text { Anolyte } \\
& 2 \mathrm{M} \mathrm{C}_{\mathrm{r}} \mathrm{Cl}_{3} / \mathrm{C}_{\mathrm{r}} \mathrm{Cl}_{2} \\
& \text { Support } \\
& 2 \mathrm{~N} \mathrm{HCl} \text { aqueous }
\end{aligned}
$$

Components, Piping \& Structure

Compatible with electrolytes

low cost, life \& maintenance

Installation

- The installation will be completely independent of any other on-site facility.

- The erection of a protective enclosure for selected component may be considered.

- The burial of selected components may be considered. 
APPENDIX C (Continued)

100-MWH REDOX ENERGY STORAGE SYSTEM DESIGN PARAMETERS

\section{Environment}

Ambient temperature: Normal range, $\mathrm{F}^{\circ}$

-15 to 95

Extremes, of

$-30,110$

Yearly average, ${ }^{\circ} \mathrm{F}$

55

Altitude, ft.

0 to 5000

Relative humidity, \%

10 to 90

Wind: Velocity, mph

0 to 110

Max. 1oad, $1 \mathrm{~b} / \mathrm{Ft}^{2}$

Snow or ice load, $1 \mathrm{~b} / \mathrm{Ft}^{2}$

80

\section{Control}

The power plant shall be designed for automatic unattended operation.

Operating modes

Supervisory controller

Primary system condition indicator

Voltage regulation (if required)

$$
\begin{gathered}
\text { Start } \\
\text { Run - Discharge } \\
\text { Run - Charge } \\
\text { Shutdown }
\end{gathered}
$$

Emergency Shutdown

Automatic/manual override

Open circuit cell voltage

Trim cells 
APPENDIX D

100 MWH CONTROLLER OPERATING MODES 



\section{APPENDIX D}

100-MWh CONTROLLER OPERATING MODES

MODE

$\underline{\text { Start }}$ (Manual)

\section{Function}

1. Verify electrolyte storage tank level with low level switches (LLS) $*$.

a. If level is low (pumps warning signal.

b. If level is $\mathrm{OK}$, continue.

2. Start all pumps and energize START light.

3. Verify electrolyte flow with flow switches (FS).

a. If no flow, shutdown, de-energize START light and energize warning signal.

b. If flow is indicated, continue.

4. Verify open circuit voltage (VOC).

a. If out of (TBD) range, shutdown, deenergize START light and energize warning signal.

b. If open circuit voltage is within TBD range, continue.

5. If any open circuit voltage is greater than 1.00 volt, terminate high flow (dual pump) operation in that loop and continue with low flow (singlepump) operation.

*Instrument notations used are consistent with Figure 10 and 11 . 


\section{APPENDIX D (Continued) \\ 100-MWh CONTROLLER OPERATING MODES}

$\underline{\text { Run-Discharge }}$

$\underline{\text { Run-Charge }}$
1. If previous mode of operation was START, and open circuit voltage (VOC) is in excess of TBD volts, connect power plant to bus, de-energize START light and energize RUNCHARGE light. Send signal to inverter/ rectifier to operate in inverter mode. RUN-DISCHARGE mode will be maintained until VOC reaches 0.96 volts.

2. If previous mode of operation was RUNCHARGE and VOC is 1.19 volts, de-energize RUN-CHARGE light, energize signal to inverter/ rectifier to operate in inverter mode. RUNDISCHARGE mode will be maintained until voltage VOC reaches 0.96 volts.

3. Whenever the VOC in any loop is greater than or equal to 1.00 volt, low flow (single-pump) operation should prevail in that loop. Whenever the VOC in any loop is less than 1.00 volt, high flow (dual pump) operation should prevail in that loop.

1. If previous mode of operation was START, and VOC is less than TBD volts, connect power plant to bus, de-energize START light and energize RUN-CHARGE light. Send signal to inverter/rectifier to operate in rectifier mode. RUN-CHARGE mode will be maintained until VOC reaches 1.19 volts. 
2. If previous mode of operation was RUNDISCHARGE and open circuit voltage VOC is 0.96 volts, de-energize RUN-DISCHARGE light and energize RUN-CHARGE 1 ight. Send signal to inverter/rectifier to operate in rectifier mode. RUN-CHARGE mode will be maintained until open circuit voltage reaches 1.19 volts.

3. Whenever the $V O C$ in any loop is greater than or equal to 1.00 volt, low flow (single-pump) operation should prevail in that loop. Whenever the VOC in any loop is less than 1.00 volt, high flow (dual pump) operation should prevail in that loop. 


\section{APPENDIX D (Continued) \\ 100-MWh CONTROLLER OPERATING MODES}

Normal Shutdown

(Shutdown is indicated by engaging SHUTDOWN

Emergency Shutdown
1. Disconnect power plant from line.

2. Stop pumps.

3. De-energize run mode light.

4. Controller may be manually shutdown if a complete shutdown is desired.

1. An emergency shutdown will be initiated if any of the following occur:

a. Low electrolyte level signal

b. open circuit voltage out of range

c. flow switch indicates no electrolyte flow 
APPENDIX E

500 -kWh, 100 MW FLOW CELL MANUFACTURING CAPITAL EQUIPMENT 
APPENDIX E

TABLE E-1

REDOX FLOW CELL MFG.

CAPITAL EQUIPMENT COSTS - 500-kWh

Item Cost Element

1. 550 ton injection molding mach. 50 oz. 1014非/hr \& rigid vinyl kit

$\$ 130,250$

2. $5 \times 12$ extruder calendar, 3 roll

$\$ 125,000$

3. 73 ton ironworker (Buffalo or Mubea)

$\$ 21,576$

4. $2 \mathrm{~K}$ modern cutoff

$\$ 24,000$

Modern auto. feed

$\$ 6,000$

5. $3 / 8 \times 6^{\prime}$ shear (American-Hercules) hydraulic H/D

$\$ 25,320$

6. 5' $5^{\prime} 13^{\prime \prime}$ radial dr. pr.

$\$ 25,950$

7. \#2 L\&G dr. pr.

$\$ 8,000$

8. $25 " \mathrm{x} 48^{\prime \prime}$ surface grinder

$\$ 40,000$

w/dust collector

$\$ 4,500$

9. 60 ton punch press

$\$ 40,000$

10. (4) spindle $d r$. head

$\$ 1,400$

11. (2) 10 ton bridge crane $\times 80$ span $\times 200^{\prime} 1 \mathrm{~g}$.

$\$ 86,000$

12. Pipe \& bolt threading lathe $1 / 4^{\prime \prime}-2^{\prime \prime}$

$\$ 3,500$

13. Welding eqpt. (oxyacetylene)

$\$ \quad 800$

14. Forklift truck

$\$ 12,000$

15. Sanders, belt (2) @ $\$ 1,500$ each

$\$ 3,000$

16. Microgrinder

w/dust collector

$\$ 35,000$

$\$ 4,500$

17. (10) Hydraulic presses @ 非12,000 each

$\$ 120,000$

18. (2) Transfer tables @ $\$ 4,000$ each

$\$ 8,000$ 
TABLE E-1 (Contd)

REDOX FLOW CELL MFG.

CAPITAL EQUIPMENT COSTS - 500-kWh

Item Cost Element

19. (2) Hydraulic shears @ $\$ 12,000$ each cutoff machine

20. (3) Roller conveyors

$\$ 1,252$

21. Vapor degreaser

$\$ 16,000$

22. Plating tank

23. Rinse tank

24. Catalyst immersion tank

$\$ 1,800$

25. Rollfeed

$\$ 3,200$

26. Coil holder (reel)

$\$ 750$

27. (2) Ovens - Precarb \& Carbonation 6 $6^{\prime} \times 6^{\prime} \times 7^{\prime}$ each

$\$ 19,000$

28. (1) Oven \& conveyor - 36' long oven - 40' conveyor

$\$ 37,000$

29. (2) Blenders

$\$ 15,000$

30. (2) Hopper loaders

$\$ 4,000$

31. (2) Hoppers

$\$ 3,600$

32. Air return system (baghouse)

$\$ 25,000$

33. Air makeup system

$\$ 12,000$

34. Portable spray booth $18^{\prime \prime} \times 192^{\prime \prime} \times 48^{\prime \prime}$ high

$\$ 5,000$

35. Spray eqpt.

$\$ \quad 800$

36. Ventilation system

$\$ 75,000$

37. Chiller

$\$ 20,000$

38. Racks, tables, hand trucks, shelving, fixtures, molds, hand tools, fixtures \& jigs

$\$ 250,000$ 
TABLE E-1 (Cont'd)

REDOX FLOW CELL MFG.

CAPITAL EQUIPMENT COSTS - 500-kWh

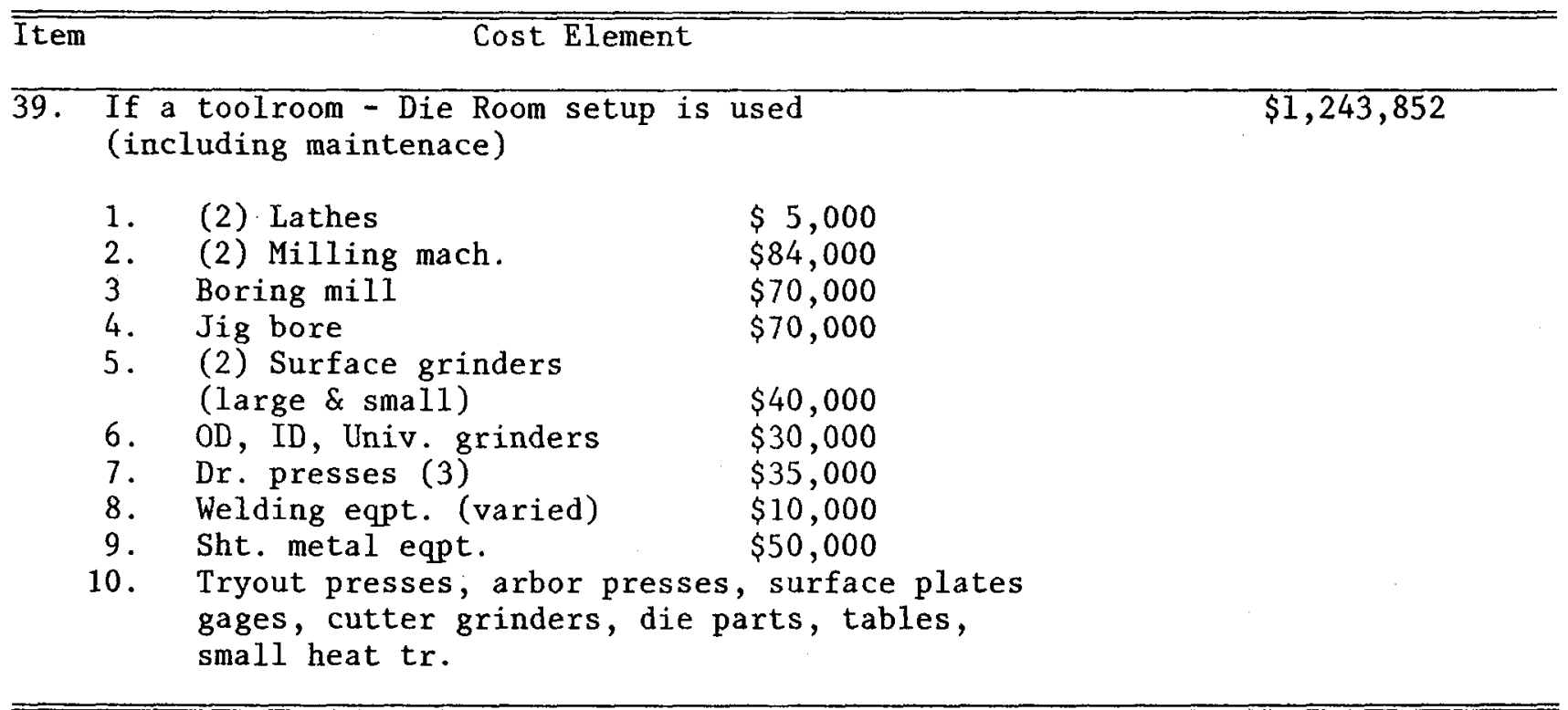


TABLE E-2

REDOX FLOW CELL MFG.

CAPITAL EQUIPMENT COSTS - 100-MWH

\begin{tabular}{|c|c|c|c|c|}
\hline Items & Units & Cost Element & Each & Total \\
\hline 1. & 27 & $\begin{array}{l}550 \text { ton injection molding mach. } 50 \% \text { of } \\
1014 \text { 非 } / \text { hr rigid vinyl kit }\end{array}$ & $\$ 130,250$ & $\$ 3,516,750$ \\
\hline 2 . & 8 & $5 \times 12$ extruder calendar 3 -roll & $\$ 125,000$ & $\$ 1,000,000$ \\
\hline 3. & 1 & 73 ton iron worker & $\$ 21,576$ & $\$ 21,576$ \\
\hline 4. & 2 & $\begin{array}{l}8 \mathrm{KD} \text { modern cutoff mach. } \\
\& \text { modern auto. feed }\end{array}$ & $\begin{array}{l}\$ 46,000 \\
\$ 12,000\end{array}$ & $\begin{array}{l}\$ 92,000 \\
\$ 12,000\end{array}$ \\
\hline 5. & 1 & $3 / 8 \times 6^{\prime}$ shear & $\$ 25,320$ & $\$ 25,320$ \\
\hline 6. & 3 & pipe \& bolt threading lathes & $\$ 3,500$ & $\$ 10,500$ \\
\hline 7. & 4 & $5^{\prime} \times 13^{\prime \prime} \mathrm{rad}$. dr. pr. & $\$ 25,950$ & $\$ 103,800$ \\
\hline 8. & 1 & $\# 2$ L\&G dr. pr. & $\$ 8,000$ & $\$ 8,000$ \\
\hline 9. & 6 & $\begin{array}{l}25 \times 48 \text { surface grinder } \\
\text { w/dust collection }\end{array}$ & $\$ 40,000$ & $\$ 240,000$ \\
\hline 10. & 1 & 4 spindle $\mathrm{d} r$. hd. & $\$ 1,400$ & $\$ 1,400$ \\
\hline 11. & 4 & $\begin{array}{l}10 \text { ton bridge cranes } \\
\text { (1) dual } 40^{\prime} \operatorname{span} \times 220^{\prime} \mathrm{lg} \& \\
\text { (2) single } 60^{\circ} \operatorname{span} \times 180^{\prime} \mathrm{lg}\end{array}$ & $\begin{array}{l}\$ 86,000 \\
\text { estimated }\end{array}$ & $\$ 344,000$ \\
\hline 12. & 2 & Qxyacetylene welding eqpt. & $\$ 800$ & $\$ 1,600$ \\
\hline 14. & 4 & Fork lift trucks & $\$ 12,000$ & $\$ 24,000$ \\
\hline 15 . & 18 & Sanders, belt & $\$ 15,000$ & $\$ 27,000$ \\
\hline 16. & 4 & Microgrinders & $\$ 35,000$ & $\$ 140,000$ \\
\hline 17 . & 12 & Hydraulic presses & $\$ 12,000$ & $\$ 144,000$ \\
\hline 18. & 64 & Transfer tables & $\$ 4,000$ & $\$ 256,000$ \\
\hline
\end{tabular}


TABLE E-2 (Continued)

REDOX FLOW CELL MFG.

CAPITAL EQUIPMENT COSTS - 100-MWH

\begin{tabular}{|c|c|c|c|c|}
\hline$\overline{\text { ITEM }}$ & UNITS & COST ELEMENT & $\overline{\mathrm{EACH}}$ & TOTAL \\
\hline$\overline{19}$. & 35 & Hydraulic shears & $\$ 23,000$ & $\$ 420,000$ \\
\hline 20 . & 3 & Roller conveyors & By length & $\$ 1,252$ \\
\hline 21 . & 16 & Belt conveyors (approx. $100^{\prime}$ each) & $\$ 180 / 10^{\prime}$ & $\$ 28,800$ \\
\hline 22 . & 1 & Vapor degreaser & $\$ 25,000$ & $\$ 25,000$ \\
\hline 23. & 1 & Plating tank & $\$ 827$ & $\$ 827$ \\
\hline 24. & 1 & Rinse tank & $\$ 827$ & $\$ 827$ \\
\hline 25 . & 27 & Catalyst immersion tanks & $\$ 1,800$ & $\$ 48,600$ \\
\hline 26. & 27 & Rollfeed & $\$ 3,200$ & $\$ 3,200$ \\
\hline 27 . & 29 & Coil holder & $\$ 750$ & $\$ 21,750$ \\
\hline 28 . & 32 & Ovens - precarb \& carb & $\$ 19,000$ & $\$ 608,000$ \\
\hline 29 . & 27 & Ovens $\mathrm{w} /$ conveyor & $\$ 37,000$ & $\$ 999,000$ \\
\hline 30. & 15 & Blenders & $\$ 9,000$ & $\$ 135,000$ \\
\hline 31. & 15 & Hopper leaders system & $\$ 4,000$ & $\$ 60,000$ \\
\hline 32 . & 3 & Air return systems & $\$ 25,000$ & $\$ 75,000$ \\
\hline 33. & 2 & Air makeup system & $\$ 12,000$ & $\$ 24,000$ \\
\hline 34. & 1 & Portable spray booth & $\$ 5,000$ & $\$ 5,000$ \\
\hline 35. & 1 & Spray eqpt. & $\$ 800$ & $\$ 800$ \\
\hline 36. & 1 & Ventilation system & $\$ 75,000$ & $\$ 75,000$ \\
\hline 37. & 2 & Chillers & $\$ 20,000$ & $\$ 40,000$ \\
\hline 38. & & $\begin{array}{l}\text { Nec. racks, trucks, shelving, } \\
\text { fixtures, hand tools, etc. }\end{array}$ & & $\$ 500,000$ \\
\hline 39 . & 64 & Presses w/heated platens & $\$ 18,000$ & $\$ 1,152,000$ \\
\hline
\end{tabular}




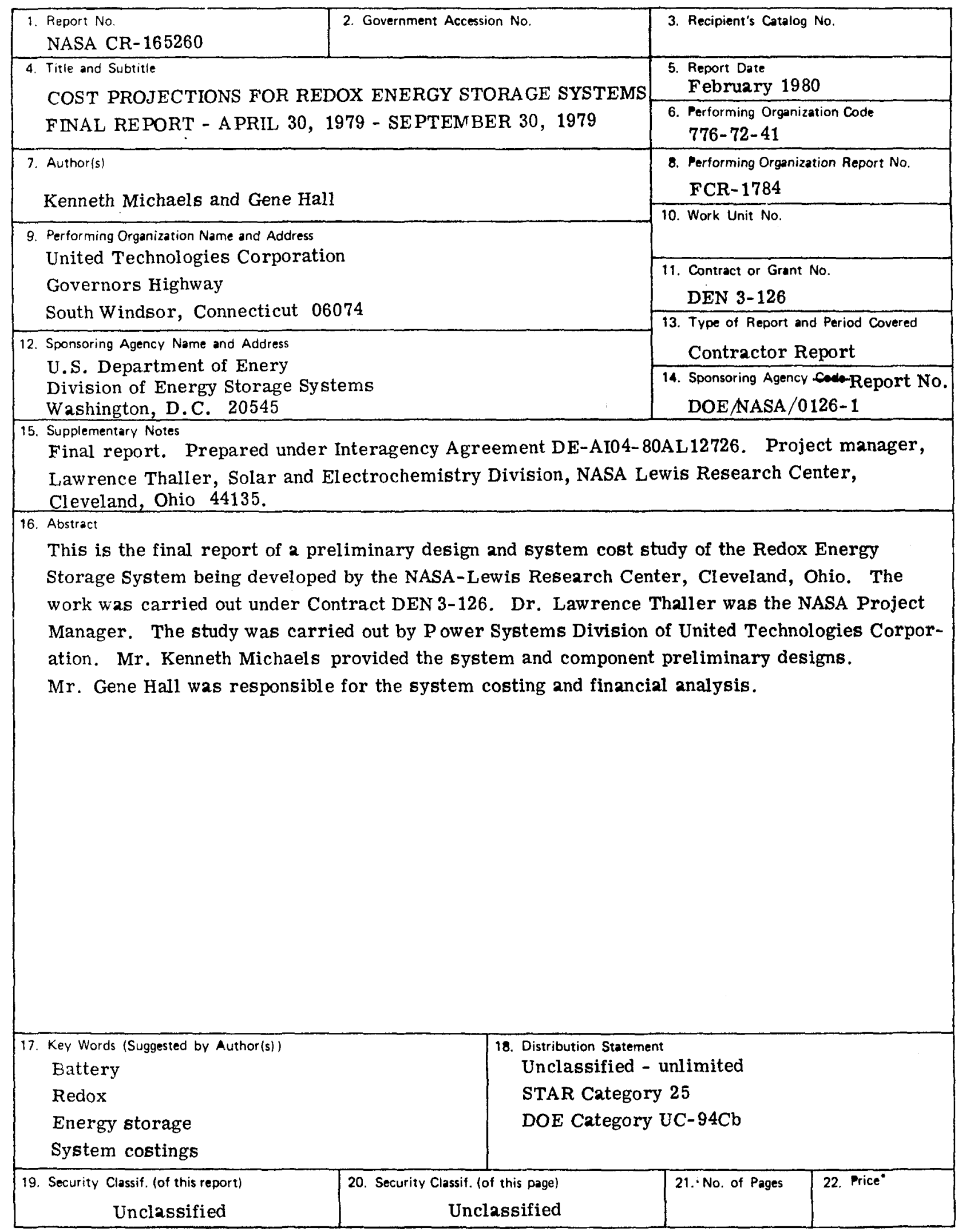

* For sale by the National Technical Information Service, Springfield, Virginia 22161 

UNITED STATES DEPARTMENT OF ENERGY

P.O. BOX 62

OAK RIDGE. TENNESSEE 37830

OFFICIAL BUSINESS

PENALTY FOR PRIVATE USE, $\$ 300$

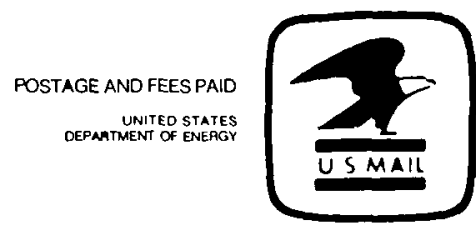

FS- 1

NATIONAL AERONAUTICS ANI SFACE AIIM

ATTN LIERARY

LANGLEY RESEAFCH CENTEF

HAMFTON, VA 23665 